\title{
ANÁLISE TEMPORAL DO USO DA TERRA EM UMA MICROBACIA HIDROGRÁFICA NO MUNICÍPIO DE PIRACICABA, SP, POR MEIO DE TÉCNICAS DE GEOPROCESSAMENTO
}

FRANCISCO JOSÉ DE OLIVEIRA PARISE

Engenheiro Agrônomo

Orientador: Prof. Dr. CARLOS ALBERTO VETTORAZZI

Dissertação apresentada à Escola supenor de Agricultura "Luiz de Queiroz", Universidade de São Paulo, para obtenção do título de Mestre em Agronomia, Área de Concentração: Irrigação e Drenagem.

\section{PIRACICABA}

Estado de São Paulo - Brasil

Maio 1999 


\section{ERRATA \& CORRIGENDA}

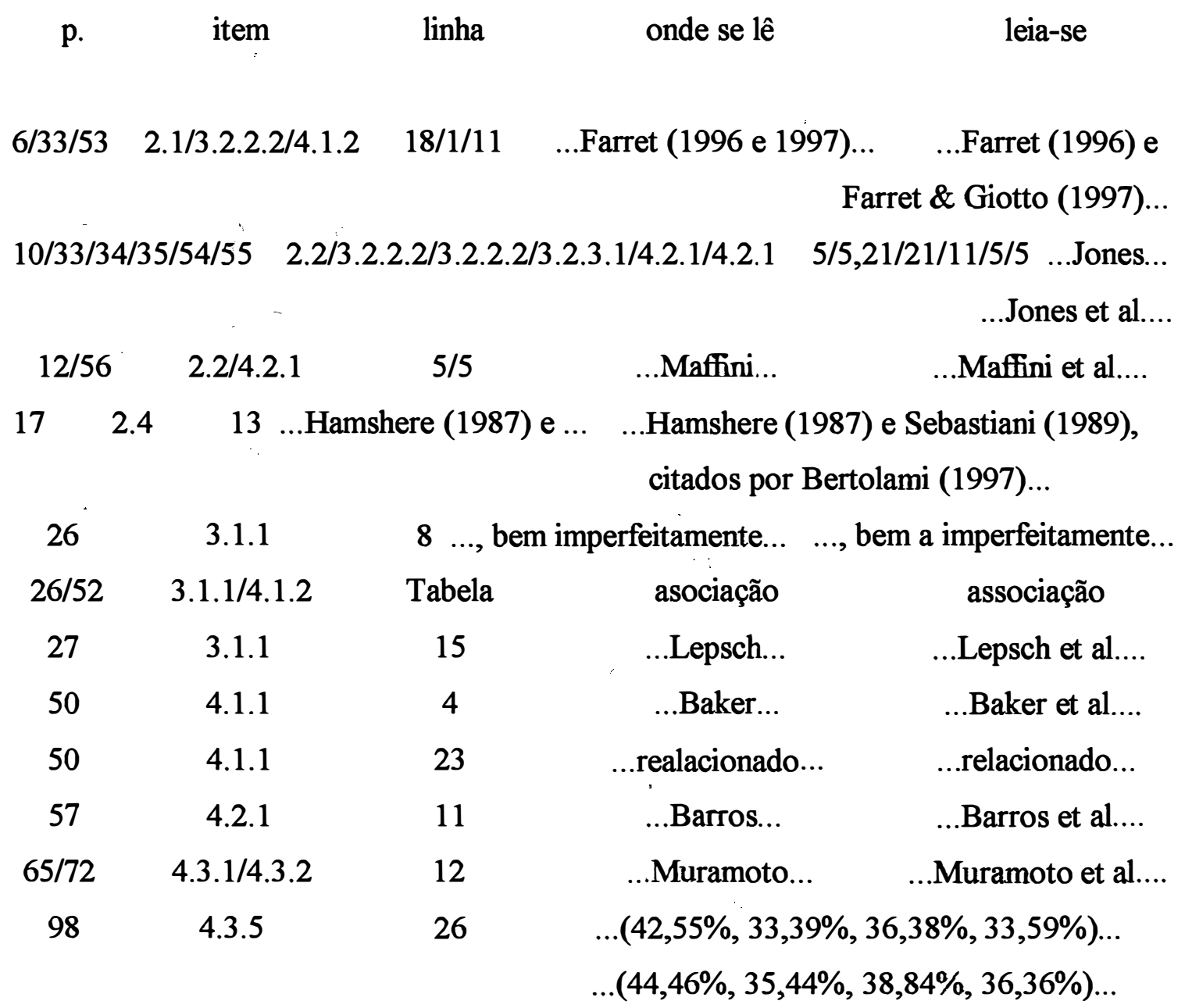


Dados Internacionais de Catalogação na Publicação (CIP) DIVISĀo DE BIBLIOTECA E DOCUMENTAÇĀO - Campus "Luiz de Queiroz"/USP

Parise, Francisco José de Oliveira Análise temporal do uso da terra em uma microbacia hidrográfica no município de Piracicaba, SP, por meio de técnicas de geoprocessamento / Francisco José de Oliveira Parise. -. Piracicaba, 1999.

114 p. : il.

Dissertação (mestrado) - - Escola Superior de Agricultura Luiz de Queiroz, 1999. Bibliografia.

1. Fotografia aérea 2. Geoprocessamento 3. Microbacia hidrográfica 4. SiG 5. Uso da terra I. Título

CDD 551.483

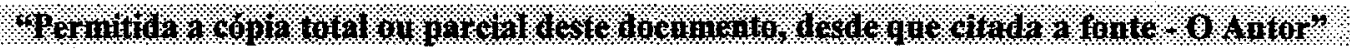


A Omar Ali Shah, Maria de Lourdes e Fernando Parise 


\section{AGRADECIMENTOS}

Ao Departamento de Engenharia Rural da Escola Superior de Agricultura "Luiz de Queiroz" pela oportunidade de cursar o programa de pós-graduação em Irrigação e Drenagem.

À Fundação Coordenação de Aperfeiçoamento de Pessoal de Nível Superior (CAPES) por custear o mestrado.

Ao Prof. Dr. Carlos Alberto Vettorazzi pela orientação, apoio e oportunidade de enriquecer meus conhecimentos.

Ao Prof. Dr. Rubens Angulo Filho pelo auxílio na fotointerpretação e pelas valorosas sugestões e aos professores Décio Eugenio Cruciani pelas sugestões e Jorge Raffo pelos esclarecimentos.

Aos pesquisadores Jener Fernando Leite de Moraes e Antonio Carlos Cavalli do Centro de Solos e Recursos Agroambientais do Instituto Agronômico de Campinas pela importante ajuda e ao pesquisador Francisco Lombardi Neto, também do IAC, pelas elucidações.

Aos alunos do curso de pós-graduação em geoprocessamento do Departamento de Engenharia de Transportes da Escola Politécnica da Universidade de São Paulo/USP, em especial na pessoa do engenheiro cartógrafo Pedro Baranga Jr., pelas explicações básicas.

Ao Prof. Dr. Rubens Duarte Coelho, ao pesquisador Athadeu Ferreira da Silva e aos engenheiros agrônomos Nelson e Axel pelos incentivos.

Aos funcionários do Departamento de Engenharia Rural e da Divisão de Biblioteca e Documentação da ESALQ.

A Jarbas, Adriana, Eder e Natália, entre outros, que valorizaram minha estadia em Piracicaba.

À Magali pela ininterrupta ajuda e apoio. 


\section{SUMÁRIO}

Página

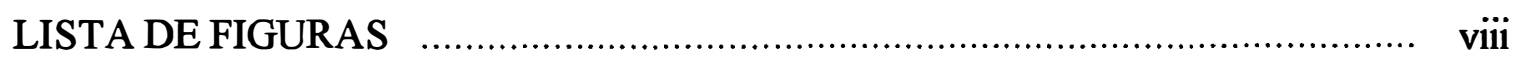

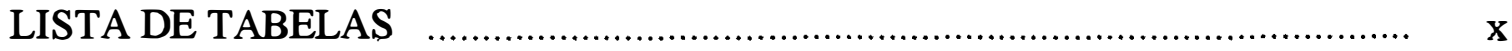

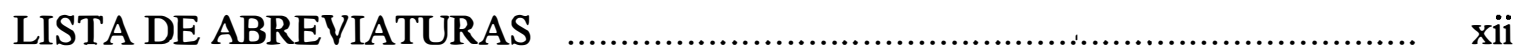

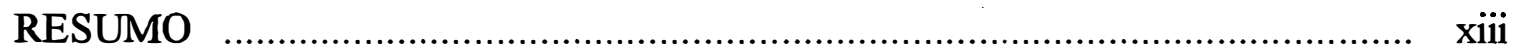

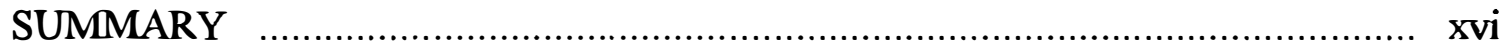

1 INTRODUÇÃO

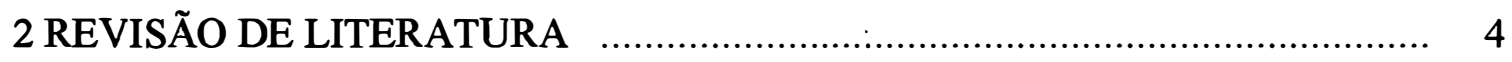

2.1 Fotografias aéreas convencionais como fonte de dados para

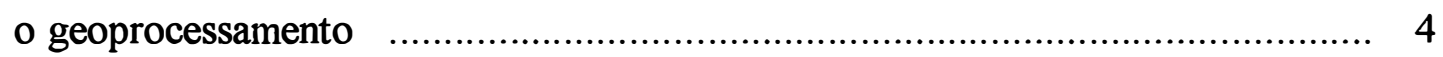

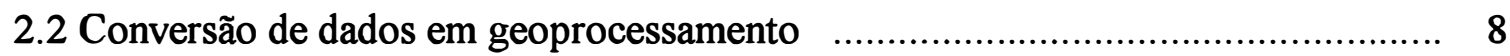

2.3 Análise temporal em geoprocessamento f........................................................ 14

2.4 Estudos de análise temporal do uso da terra por meio

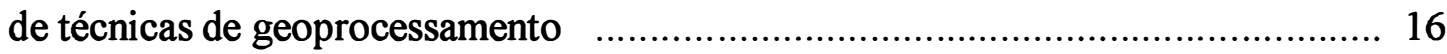

3 MATERIAL E MÉTODOS …............................................................... 23

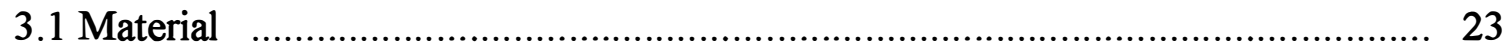

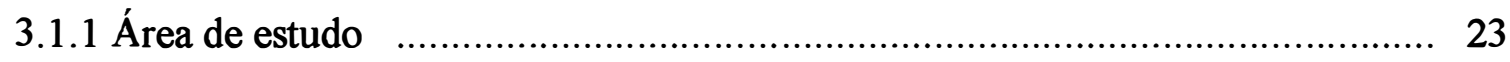

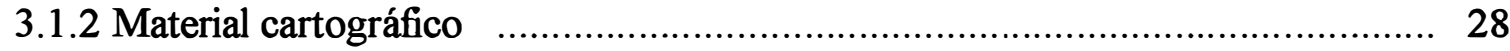

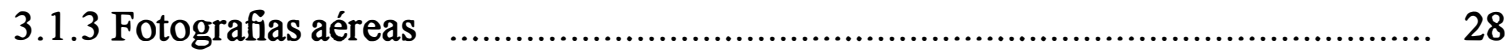

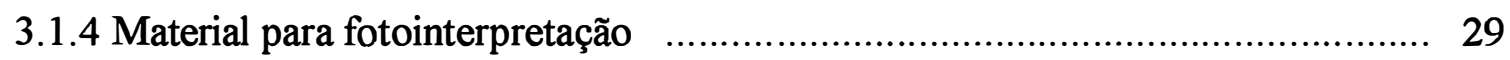

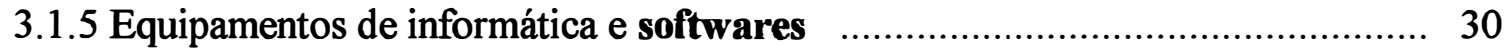

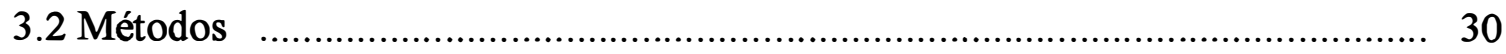

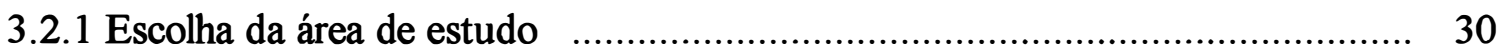


Página

3.2.2 Levantamento e preparação dos dados ...................................................... 31

3.2.2.1 Fotointerpretação e definição da legenda ................................................. 31

3.2.2.2 Preparação do material a ser digitalizado ……........................................ 32

3.2.3 Conversão dos dados ......................................................................... 35

3.2.3.1 Digitalização e edição dos dados ....................................................... 35

3.2.3.2 Transformação de arquivos vetoriais em matriciais .................................. 36

3.2.3.3 Geração do modelo digital do terreno e do mapa de classes de declividade .. 37

3.2.3.4 Geração dos mapas de combinações das unidades de solo com as classes de declividade, de classes de capacidade de uso e de adequação de uso da terra

3.3 Escolha da função do Sistema de Informações Geográficas utilizado e elaboração do modelo cartográfico ……......................................................... 39

3.4 Análise temporal do uso da terra …….................................................. 41

3.4.1 Situação da microbacia em 1995 ........................................................... 41

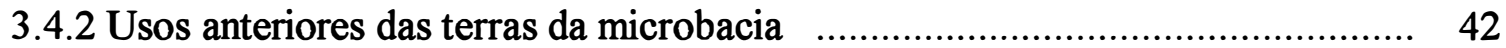

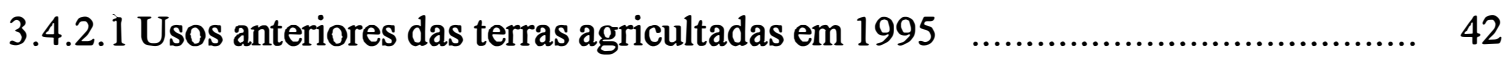

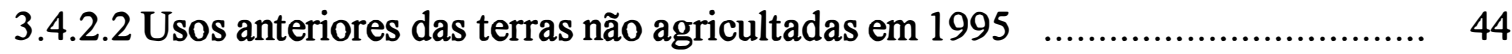

3.4.3 Composição do quadro de uso das terras da microbacia em 1995 ................. 44

3.4.3.1 Composição das terras agricultadas em 1995 ............................................ 44

3.4.3.2 Composição das terras não agricultadas em 1995 ..................................... 45

3.4.4 Dinâmica temporal de ocupação da categoria vegetação nativa $\quad$...................... 45

3.4.5 Ocupação das áreas de preservação permanente .......................................... 45

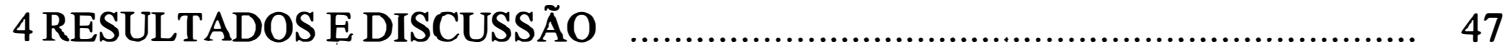

4.1 Levantamento e preparação dos dados ...................................................... 47

4.1.1 Fotointerpretação e definição da legenda .................................................... 47

4.1.2 Seleção dos pontos de controle .............................................................. 52 
Página

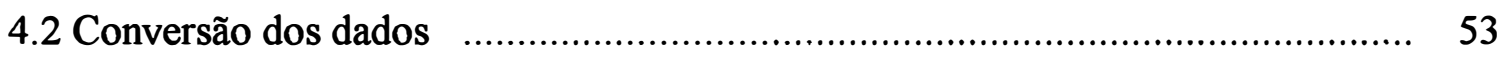

4.2.1 Digitalização e edição dos dados .................................................... 53

4.2.2 Transformação de arquivos vetoriais em matriciais .................................. 57

4.2.3 Dados obtidos de unidades de solo, modelo digital do terreno e

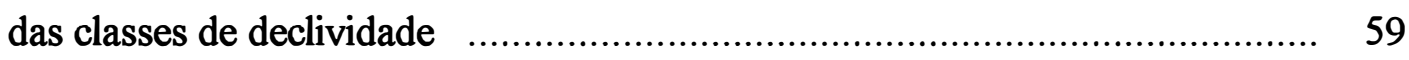

4.2.4 Dados obtidos de combinações das unidades de solo com as classes de

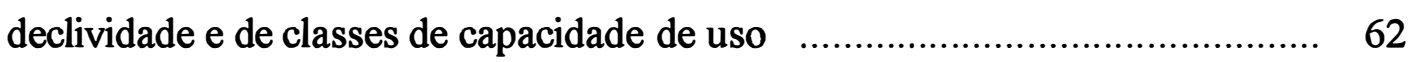

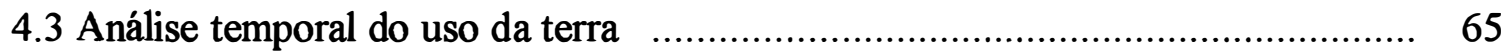

4.3.1 Situação da microbacia em 1995 ....................................................... 65

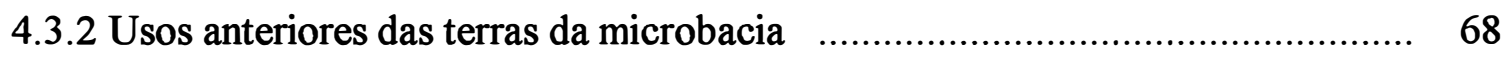

4.3.2.1 Usos anteriores das terras agricultadas em 1995 ................................. 72

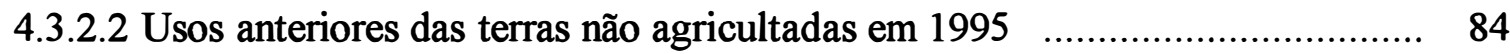

4.3.3 Composição do quadro de uso das terras da microbacia em 1995 ................. 90

4.3.3.1 Composição das terras agricultadas em 1995 ....................................... 90

4.3.3.2 Composição das terras não agricultadas em 1995 .................................. 94

4.3.4 Dinâmica temporal de ocupação da categoria vegetação nativa $\quad$.................... 97

4.3.5 Ocupação das áreas de preservação permanente $\quad$...................................... 98

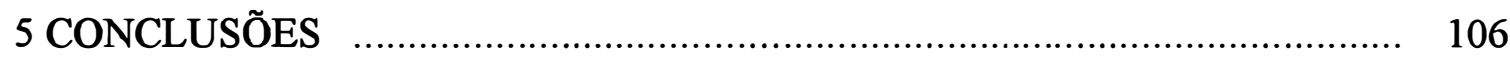

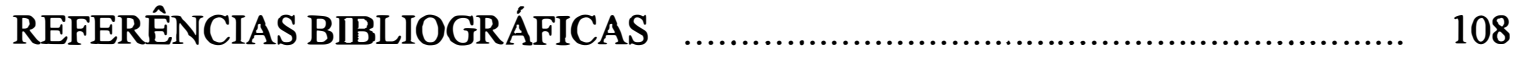




\section{LISTA DE FIGURAS}

Página

1. Área de estudo (microbacia hidrográfica do Ribeirão Pau d'Alhinho)

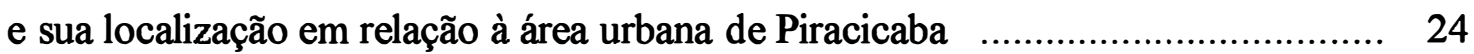

2. Unidades de solo da microbacia hidrográfica do Ribeirão Pau d'Alhinho f.......... 25

3. Modelo cartográfico elaborado para a análise temporal

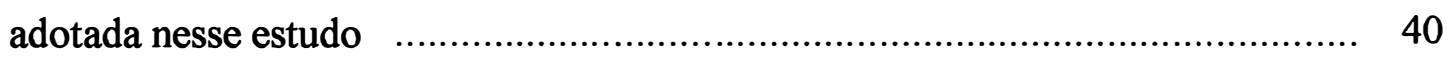

4. Modelo digital do terreno da microbacia hidrográfica do Ribeirão Pau d'Alhinho .......................................................................... 60

5. Classes de declividade da microbacia hidrográfica do

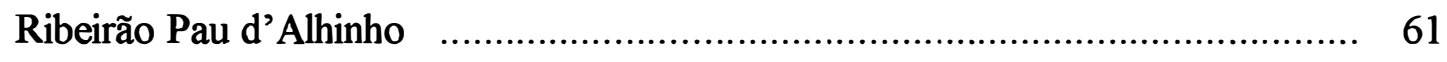

6. Combinações das unidades de solo com as classes de declividade

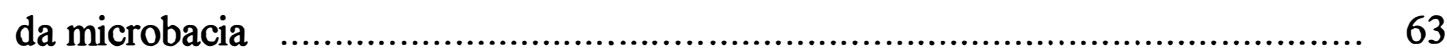

7. Classes de capacidade de uso da microbacia hidrográfica do Ribeirão Pau d'Alhinho ........................................................................... 64

8. Uso da terra na microbacia em 1995 ............................................................ 66

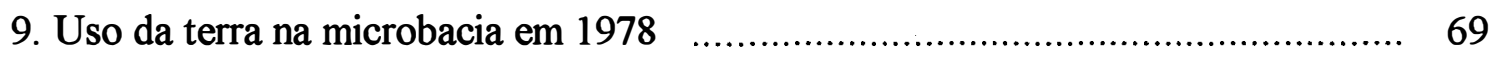

10. Uso da terra na microbacia em 1962 ....................................................... 70

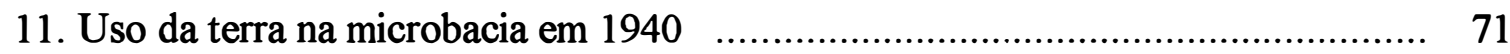

12. Adequação de uso das terras da microbacia em 1995 ...................................... 73

13. Adequação de uso das terras da microbacia em 1978 ...................................... 74

14. Adequação de uso das terras da microbacia em 1962 ....................................... 75

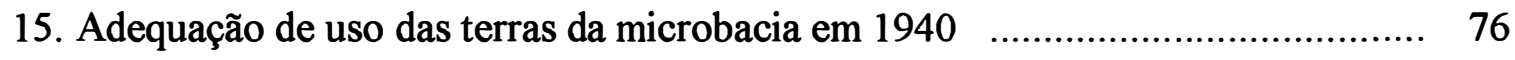

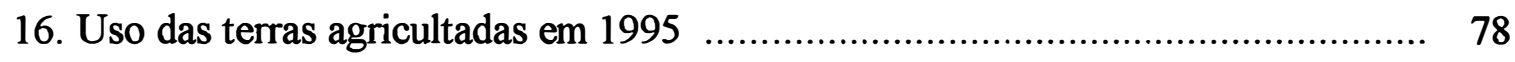

17. Uso em 1978 das terras agricultadas em 1995 ............................................ 79

18. Uso em 1962 das terras agricultadas em 1995 ........................................... 80

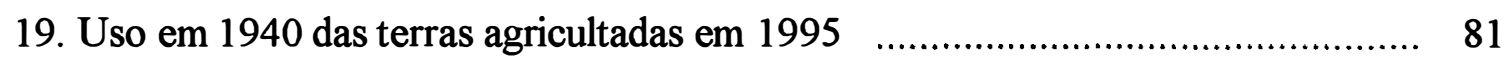




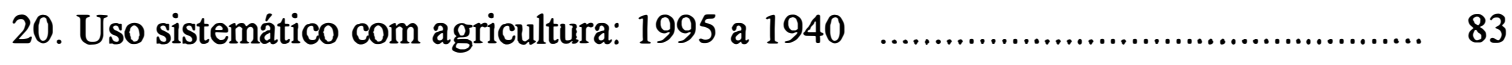

21. Uso das terras não agricultadas em 1995 ................................................ 85

22. Uso em 1978 das terras não agricultadas em 1995 ................................... 86

23. Uso em 1962 das terras não agricultadas em 1995 .................................... 87

24. Uso em 1940 das terras não agricultadas em $1995 \quad$...................................... 88

25. Dinâmica temporal de distribuição da categoria vegetação nativa

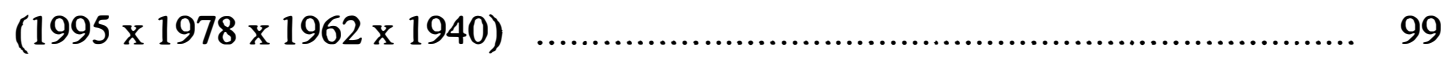

26. Uso em 1995 das terras em áreas de preservação permanente $\quad$.......................... 100

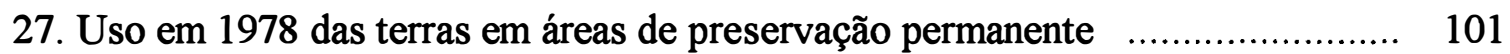

28. Uso em 1962 das terras em áreas de preservação permanente $\quad$...................... 102

29. Uso em 1940 das terras em áreas de preservação permanente $\quad \ldots \ldots \ldots \ldots \ldots \ldots \ldots \ldots . . . . . . . . . . .103$ 


\section{LISTA DE TABELAS}

Página

1. Uso da terra da microbacia hidrográfica do Ribeirão Pau d'Alhinho

2. Adequação de uso da terra da microbacia hidrográfica do Ribeirão Pau d'Alhinho ............................................................................ 22

3. Áreas das unidades de solo da microbacia f............................................... 26

4. Áreas das classes de declividade da microbacia f.............................................. 27

5. Especificações para definição das classes de capacidade de uso ....................... 38

6. Especificações para definição da adequação de uso da terra ............................ 38

7. Chave de interpretação para os alvos da área de estudo ................................... 48

8. Números de pontos de controle demarcados, descartados e

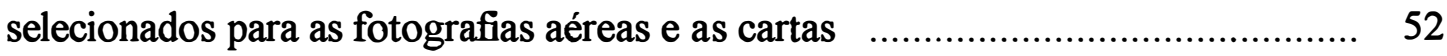

9. Erros médios quadráticos para os produtos digitalizados …............................ 53

10. Tamanho relativo dos arquivos gerados e tempo relativo de processamento, em função do tamanho dos pixels

11. Áreas das diversas categorias de uso da terra, obtidas dos respectivos mapas com diferentes tamanhos de pixel $(10 \mathrm{~m} \times 10 \mathrm{~m}, 5 \mathrm{~m} \times 5 \mathrm{~m}, 3 \mathrm{~m} \times 3 \mathrm{~m}, 1 \mathrm{~m} \times 1 \mathrm{~m}) \quad$. 58

12. Áreas das unidades de solo da microbacia .................................................... 59

13. Áreas das classes de declividade da microbacia $\quad$.............................................. 59

14. Áreas das combinações das unidades de solo com

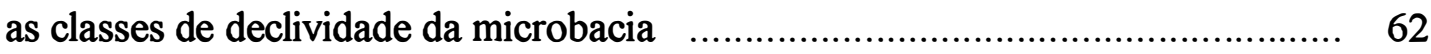

15. Áreas das classes de capacidade de uso das terras da microbacia $\ldots \ldots \ldots \ldots \ldots \ldots \ldots . . . .65$

16. Áreas das combinações de unidades de solo com classes de declividade e de classes de capacidade de uso ocupadas com a cultura

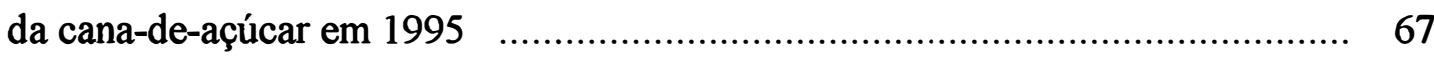

17. Áreas das diferentes categorias de uso da terra f.............................................. 68

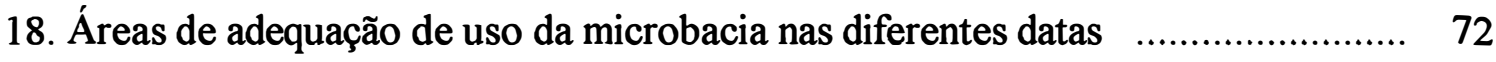


Página

19. Áreas das categorias de uso em 1995, 1978, 1962 e 1940 das terras agricultadas em 1995

20. Áreas de adequação de uso em 1995, 1978, 1962 e 1940 das terras agricultadas em 1995

21. Áreas das combinações de uso com classes de capacidade de uso nas terras sistematicamente agricultadas: 1995 a 1940

22. Áreas das categorias de uso em 1995, 1978, 1962 e 1940 das terras não agricultadas em 1995

23. Áreas das combinações de unidades de solo com classes de declividade nas terras sistematicamente utilizadas com pasto: 1995 a 1940

24. Áreas de adequação de uso em 1995, 1978, 1962 e 1940 das terras não agricultadas em 1995

25. Áreas de uso em 1995, 1978, 1962 e 1940 das combinações de unidades de solo com classes de declividade e classes de capacidade de uso das terras agricultadas em 1995

26. Áreas de uso em 1995, 1978, 1962 e 1940 das combinações de unidades de solo com classes de declividade e classes de capacidade de uso das terras não agricultadas em 1995

27. Áreas das categorias de uso em 1995, 1978, 1962 e 1940 das terras em áreas de preservação permanente

28. Áreas das categorias de uso em 1995, 1978, 1962 e 1940 das cabeceiras de drenagem da microbacia 


\section{LISTA DE ABREVIATURAS}

v. nat.: vegetação nativa

reflor. : reflorestamento

c. an. : culturas anuais

c. prm. : culturas permanentes

lot. rural : loteamento rural

lot. urb. : loteamento urbano

repres. : represas

miner. : mineração

ccu : classes de capacidade de uso

adq. : adequação

assoc. : associação

cl. de decl. : classes de declividade 


\title{
ANÁLISE TEMPORAL DO USO DA TERRA EM UMA MICROBACIA HIDROGRÁFICA NO MUNICÍPIO DE PIRACICABA, SP, POR MEIO DE TÉCNICAS DE GEOPROCESSAMENTO
}

\author{
Autor : Francisco José de Oliveira Parise \\ Orientador : Carlos Alberto Vettorazzi
}

\section{RESUMO}

Em resposta a alguns questionamentos suscitados pela adoção da metodologia usual de análise temporal do uso da terra por meio de técnicas de geoprocessamento, desenvolveu-se o presente estudo na microbacia hidrográfica dó Ribeirão Pau d'Alhinho, Município de Piracicaba, SP. Foram utilizadas como fontes de dados fotografias aéreas convencionais de 1995, 1978, 1962 e 1940, bem como técnicas e instrumentos de geoprocessamento para conversão e análise dos dados.

Os resultados da fotointerpretação foram desenhados sobre folhas de poliéster transparente (overlays) e digitalizados manualmente via mesa. Os arquivos vetoriais criados para cada fotografia foram unidos e editados e, posteriormente, transformados para formato matricial (raster) por meio de um Sistema de Informações Geográficas (SIG), utilizado também para análise dos dados.

A análise temporal foi desenvolvida, principalmente, por meio das funções tabulação cruzada, cálculo de área e reclassificação do SIG e compreendeu o estudo do uso mais recente e anterior das terras da microbacia. Os resultados de uso foram comparados aos dados combinados de solo e declividade, fornecendo, entre outros, a adequação de uso das terras da área de estudo. Foram examinadas também, à parte, a categoria vegetação nativa e as áreas de preservação permanente. 
Os resultados mostraram que as fotografias aéreas de 1940, a despeito de suas limitações técnicas, não somente podem ser usadas, sob determinadas condições, como também se transformam num instrumento enriquecedor de análise e de confirmações de tendências.

As geometrias de pontos de controle selecionadas para conversão dos dados apresentaram, em todos os casos, graus de erro abaixo do limite aceitável e resultados de exatidão compatíveis com as especificações do trabalho. No entanto, a correção dos erros, visíveis após a união dos arquivos vetoriais de uso da terra, demandou trabalho exaustivo, o que leva a pensar em transferir os dados para mapasbase antes de sua conversão. Outra dificuldade foi visualizar as linhas delimitadoras das categorias de uso da terra durante o processo de digitalização. Quanto ao tamanho do pixel, $5 \mathrm{~m}$ foi o que apresentou os melhores resultados combinados dos fatores representação das feições digitalizadas, tempo de processamento e tamanho de arquivo.

O estudo confirmou que, apesar da microbacia hidrográfica do Ribeirão Pau d'Alhinho apresentar predomínio de terras com baixa aptidão para cultivo intensivo, a cultura da cana-de-açúcar era a categoria predominante em 1995. Esse fato faz denotar uma porcentagem expressiva de terras com uso inadequado, ao mesmo tempo que as áreas aptas à agricultura não eram cultivadas em sua totalidade. Além disso, averiguou-se que uma parcela significativa das terras já era cultivada em 1940, principalmente, com uso inadequado e, em geral, nas mesmas terras lavradas em 1995. O estudo mostrou, ainda, que uma parte representativa das terras da microbacia $(10,25 \%)$ foi usada com agricultura de forma inadequada e sistemática nas quatro datas abordadas. Por outro lado, constatou-se que, apesar da categoria vegetação nativa ocupar em 1995 aproximadamente $8 \%$ da microbacia e, em 1940, 12\%, ela apresentou uma grande dinâmica de mudanças. Já as áreas de preservação permanente tenderam a ser cobertas por pasto em todo o período estudado. 
Por fim, é cabível afirmar que a metodologia usual de análise temporal do uso da terra por meio de técnicas de geoprocessamento é oportuna, ainda que possa ser facilitada pela ampliação dos decalques (overlays) e pela transferência dos dados para mapas-base antes de sua conversão. $\mathbf{O}$ tipo de análise revelou-se vantajoso, uma vez que possibilitou investigar o histórico de ocupação das terras, tomando especialmente como referência o uso mais recente. 


\title{
MULTITEMPORAL LAND USE DATA ANALYSIS OF A RURAL WATERSHED IN PIRACICABA, SP, USING GIS TECHNOLOGY
}

\author{
Author : Francisco José de Oliveira Parise \\ Adviser : Carlos Alberto Vettorazzi
}

\section{SUMMARY}

In order to answer some questions related to the usual methodology of temporal land use data analysis using geographic information systems (GIS) technology, this study was developed at Ribeirão Pau d'Alhinho watershed in Piracicaba, SP. It were used conventional aerial photographs for 1995, 1978, 1962 and 1940 as data sources and GIS techniques to data conversion and analysis.

The land use categories were delineated onto clear mylar overlays and then were converted to digital format employing a digitizing table. The vector files created were concatenated and edited, and later rasterized by Idrisi for Windows 2.0 software, also used in data analysis.

The multitemporal analysis was developed by the crosstabulation, area determination and reclassification GIS functions and priorized examine recent and past land use data. The land use data layers were overlaid to soil-type and slope combined data layer to verify land use adequacy and degradation potential. Natural vegetation data and preservation areas were investigated, too.

It was shown that the use of 1940 aerial photographs, despite of their technical limitations, improved historical land use and trends analysis. 
The sets of control points elected to coordinates transformation had errors less than the allowable RMS (root mean square) errors, and so all maps meet the U.S. National Map Accuracy Standards. However, the correction of errors visible after land use vector files concatenation consumed a lot of time. Thus, the land use categories delineated on the mylar overlays should be transferred to base maps before data conversion. Another problem was to visualize the land use category boundaries during digitizing process. Yet, the $5 \mathrm{~m}$ pixel size produced the best results regarding features representation, time processing and data volume.

The multitemporal land use data analysis indicated that Pau d'Alhinho watershed was predominantely covered by sugar cane in 1995, regardless its low agricultural suitability, demonstrating land use inadequacy. Simultaneously, arable lands were not entirely cultivated. Since 1940 , a significant portion of land was already cultivated, in general, the same land which are nowadays tilled. $10.25 \%$ of study area was always inadequately used, suggesting land degradation. Natural vegetation category was covering approximately $8 \%$ and $12 \%$ of the watershed in 1995 and 1940, respectively, but its spatial distribution changed greatly. Preservation areas were misused specially as pastures.

It was confirmed in this research that the usual methodology of temporal land use data analysis is adequate, although it could be improved enlarging the scales of overlays and transferring land use data to base maps prior to data conversion. The multitemporal land use data analysis adopted was advantageous since allowed to investigate past referenced to recent land use. 
"A terra é a fonte de todo bem-estar material. Dela retiramos tudo que usamos ou valorizamos, desde comida, roupa e abrigo até combustível, metais e pedras preciosas. Nós vivemos nela e dela e para ela nossos corpos ou cinzas são depositados quando morremos. $A$ disponibilidade de terra é a chave para a existência humana e sua distribuição e uso são de vital importância."

Simpson (1976) 


\section{INTRODUÇÃO}

A terra é um bem de vital importância para o homem, pois, além de ser o espaço sobre o qual ele vive, ela está direta ou indiretamente ligada a sua sobrevivência. Uma análise temporal do uso da terra, ao estudar a dinâmica de ocupação num determinado período de tempo, explicita as diversas relações estabelecidas entre o homem e esse bem. Como área de pesquisa, ela tem uma série de vertentes. Ultimamente, em função da crescente necessidade de monitoramento do meio ambiente cada vez mais abrangente e sistemático, essa área floresceu, em especial na última década, incluindo o Brasil.

Assim, trabalhos de avaliação de impacto ambiental em diferentes épocas, traduzidos na forma de estimativa de perdas de solo, desmatamento e qualidade de água, estudos sobre a expansão de áreas urbanas correlacionada ao meio fisico, todos visando ao planejamento, têm se destacado.

Geralmente, essas pesquisas utilizam como unidade de estudo a bacia ou microbacia hidrográfica, uma vez que, além de ser ideal por favorecer o desenvolvimento de muitos conceitos hidrológicos, biogeoquímicos e ambientais, é a que melhor reflete os impactos das interferências antrópicas. Ainda, sua escolha como unidade facilita a interpretação dos dados e o planejamento conservacionista (Sparovek \& Lepsch, 1998).

A bacia do Rio Piracicaba, na qual está inserida a microbacia hidrográfica do Ribeirão Pau d'Alhinho, área de estudo deste trabalho, tem sido alvo de diversos 
projetos de pesquisa e desenvolvimento. Afinal, ela possui uma das maiores concentrações de indústrias e população do Brasil, conseqüentemente, observa-se um grande impacto sobre os recursos naturais disponíveis e uma enorme disputa por esses recursos, ocasionando sua alteração e escassez.

Diversos trabalhos de análise temporal utilizam as fotografias aéreas convencionais como fonte de dados, sobretudo aqueles que abrangem um período anterior ao uso corrente das imagens de satélite. Esses dados podem ser convertidos e manipulados por meio de técnicas de geoprocessamento, que coletam e tratam informações georreferenciadas.

Não obstante seja indiscutível a pertinência de sua utilização, alguns questionamentos surgem associados à aplicação da metodologia usual de análise temporal. Ressalta-se que qualquer trabalho que recorra a essa metodologia, obviamente tem que cumprir etapas que, por serem inerentes ao processo, dificilmente suscitam reflexão sobre suas funções e conseqüências. Portanto, um esforço no sentido de avaliar cada uma delas, hipoteticamente, poderia facilitar o trabalho e também melhorar a confiabilidade dos resultados.

Assim, na etapa de levantamento dos dados, é viável o uso de fotografias aéreas muito antigas como fonte de dados, uma vez que o uso da terra, em geral, era bem diferente do atual e a credibilidade na memória das pessoas em relação a particularidades é duvidosa? Os resultados de sua fotointerpretação podem ser considerados confiáveis? É possível extrair pontos de controle dessas fotografias mais antigas que permitam um georreferenciamento apropriado das imagens? Afinal, a seleção dos pontos de controle acarreta conseqüências. Quais seriam elas?

Quanto à etapa de conversão dos dados, muitas vezes a área de estudo está representada em mais de uma fotografia e os arquivos vetoriais dos decalques (overlays) precisam ser unidos. O que está envolvido no processo de união dos arquivos 
digitalizados separadamente? Além disso, fotografias contêm distorções específicas associadas a sua forma de representação da realidade e o processo para que isso seja feito. Como essas distorções e o próprio georreferenciamento interferem na qualidade e confiabilidade dos dados?

A análise temporal dos dados demanda o uso de algumas funções do Sistema de Informações Geográficas utilizado. Nesses estudos temporais, o número de combinações resultantes pode ser alto, o que dificulta a apresentação dos resultados e a verificação de tendências. Como lidar com a situação exposta acima? Por fim, como analisar temporalmente o uso que os proprietários rurais de uma microbacia deram às suas terras?

Tendo como referência todos esses questionamentos, os objetivos traçados para esse trabalho foram:

- investigar o uso de fotografias aéreas de diversas épocas, principalmente quanto aos aspectos de interpretação e correções geométricas, visando seu emprego em análises temporais do uso da terra por meio de técnicas de geoprocessamento;

- avaliar o processo de conversão dos dados e algumas funções de um Sistema de Informações Geográficas do tipo matricial, como instrumento de análise temporal do uso da terra;

- analisar o uso mais recente e anterior das terras da microbacia hidrográfica do Ribeirão Pau d'Alhinho, como base para possíveis intervenções com vistas ao seu uso adequado. 


\section{REVISÃO DE LITERATURA}

\subsection{Fotografias aéreas convencionais como fonte de dados para o geoprocessamento}

A fotografia aérea convencional é um material de grande valor para o geoprocessamento, principalmente por ser um documento que apresenta quantidade abundante de informações visuais confiáveis, obtidas por meio dos processos de medição e interpretação da imagem. Além disso, possibilita visão tridimensional. Uma das áreas para sua aplicação é a interpretativa ou fotointerpretação. Ela baseia-se na interpretação fotográfica e trata da identificação de objetos e determinação da significância desses.

A identificação de objetos apoia-se no "princípio de convergência de evidências", que aponta a sua provável identidade. No caso de fotografias aéreas convencionais, as "evidências" indicam a identidade de um objeto baseadas, conforme SANTOS et al. (1980), no resultado integrado de fatores como tonalidade, textura, padrão, forma, dimensão, sombra, cor, sítio topográfico e relações de aspecto dos objetos representados nas fotografias. Esses fatores foram denominados por Marchetti (1978) de elementos de reconhecimento. Com relação a isso, Fiorio (1998), Borges et al. (1993) e Koffler et al. (1979), trabalhando na região canavieira de Piracicaba, destacaram os elementos textura, porte, tonalidade e aspectos associados como os mais importantes para identificação dos alvos encontrados em suas pesquisas. Audi (1965), estudando a mesma região, constatou que um aspecto homogêneo do telhado com ondulações acompanhando o terreno; uma extensão de área relativamente grande, toda recortada com carreadores; uma tonalidade clara admitindo pequenas variações; uma 
textura adensada e aveludada foram características importantes para a identificação da cultura de cana-de-açúcar.

No processo de identificação, o fotointérprete vale-se de chaves de interpretação que o auxiliam na organização das informações contidas nas fotografias aéreas, orientando-o para a correta escolha da identidade dos objetos. Essas chaves, também chamadas de chaves de classificação, podem ter o caráter de seleção ou de eliminação. As de seleção são aquelas montadas para o fotointérprete escolher na chave um identificador semelhante ao da fotografia e as de eliminação, ao contrário, para eliminar os dessemelhantes e ficar com o não eliminado. Koffler et al. (1979) desenvolveram uma chave de interpretação para auxiliar o fotointérprete na identificação de alvos em fotografias aéreas verticais, escala 1:35.000, na grande região canavieira de Piracicaba.

No que concerne à visibilidade de objetos nas fotografias aéreas, Anderson (1982) afirmou que ela varia consideravelmente conforme certas características próprias dos objetos e do tipo, escala e qualidade das fotografias. Quanto ao último fator, Baker et al. (1979) defenderam a idéia de que fotografias aéreas antigas tendem a prejudicar a identificação de objetos e o nível de detalhamento. Assim, quando se trabalha com fotografias aéreas de várias datas, é recomendável iniciar o processo de fotointerpretação pelas fotografias mais recentes e terminá-lo pelas mais antigas, seguindo uma seqüência retrospectiva, como fez Bertolami (1997).

Audi (1965), trabalhando sobre as fotografias aéreas de 1962 da região canavieira de Piracicaba, verificou que, no caso de áreas muito pequenas e isoladas, como é o das forrageiras (geralmente situadas próximas a pastos, retiros e outras construções, denunciando exploração de gado), foi fácil confundir áreas de cana-de-açúcar com pasto limpo e capim alto. 
No que diz respeito ao fator escala, Fiorio (1998), usando fotografias aéreas convencionais de quatro datas, constatou que as fotografias com escala 1:35.000 (de 1978) foram as de mais fácil interpretação. Ainda, afirmou que essa escala proporcionou o mesmo grau de detalhamento que as de 1:25.000 (fotografias de $1995 \mathrm{e}$ 1962). Por outro lado, Borges et al. (1993) cogitou que diferentes escalas e épocas dos produtos fotográficos poderiam prejudicar ligeiramente o nivel de detalhamento obtido.

$\mathrm{Na}$ etapa de fotointerpretação existem diferentes métodos para obtenção das informações. Por exemplo, Montgomery \& Schuch (1993) comentaram que os objetos podem ser identificados e digitalizados diretamente por equipamentos de digitalização estereoscópica, ou as fotografias podem ser copiadas por scanner e a interpretação feita por um programa de análise de imagens.

Quando as especificações do trabalho não demandam uma exatidão elevada, outro método pode ser adotado. Nele, as feições dos objetos são diretamente traçadas sobre folhas de poliéster ou acetato transparentes (overlays) sobrepostos às fotografias aéreas. Wolf (1983) expôs que, para se manter um nível satisfatório de exatidão, há a necessidade de se plotar alguns pontos de controle da fotografia (pontos cujas coordenadas são conhecidas), distribuídos uniformemente através dela, no decalque (overlay). Quanto a isso, Farret (1996 e 1997) afirmou que, trabalhando-se diretamente sobre aerofotografias de pequeno formato não retificadas, a melhor geometria de pontos de apoio (pontos de controle) é um ponto em cada um dos cantos da fotografia.

Wolf (1983) ponderou, entretanto, que a fotografia aérea não é considerada um mapa e possui variações de escala e deslocamentos devido ao relevo. Além disso, pode conter distorções causadas pela inclinação da câmara (tilt) e, segundo Carvalho, citado por Farret (1996), também pelo sistema de projeção que apresenta. Com relação aos principais fatores que causam desuniformidade na escala - irregularidade topográfica, principalmente, e inclinação do eixo ótico da câmara no momento da tomada 
da aerofotografia - Farret (1996) explicou que a geometria de um ponto em cada um dos cantos da fotografia estabelece a média entre esses fatores.

Apesar dessas restrições, Wolf (1983) considerou que, por meio do controle combinado entre pontos da fotografia com coordenadas conhecidas e do decalque em áreas específicas, erros dessas fontes podem ser minimizados. Se variações do terreno são moderadas e não houver inclinação exagerada da câmara, resultados exatos poderiam ser alcançados.

Já, Bolstad (1992) afirmou que o uso direto de fotografias aéreas convencionais deve ser evitado para grande parte das condições. Sob relevo moderado a forte ondulado ou escalas menores que 1:20.000, isso é particularmente válido. Sua utilização é especialmente restritiva se os dados forem incluídos num sistema de análise automática ou uma exatidão elevada nas estimativas de área seja requerida. Entretanto, conforme o autor, muitos bancos de dados de recursos naturais são construídos por meio deste método, em função de seu baixo custo. Bolstad (1992) explicou que, mesmo removendo algumas distorções por meio das técnicas de transferência dos dados para um mapa-base, que é um mapa de exatidão elevada, ou da utilização de instrumentos de reflexão ou projeção (por exemplo, o zoom transfer scope), erros geométricos elevados permanecerão, decorrentes unicamente da inclinação da câmara. Assim, esses erros, juntamente com aqueles provenientes dos deslocamentos devido ao relevo, resultariam em níveis inaceitáveis para muitas análises. Em razão disso tudo, somado à disponibilidade e baixo custo das tecnologias de correção das fotografias aéreas, o autor defendeu o uso de métodos analíticos para remoção das distorções causadas pelo relevo e inclinação da câmara.

Em contrapartida, Farret (1996) declarou que o uso direto, sem qualquer trabalho de retificação, de aerofotografias de pequeno formato, em condições de declividade baixa, produz erros compatíveis com os padrões de exatidão. Além disso, 
esse procedimento, por seu baixo custo, viabiliza sua utilização por prefeituras com recursos limitados, principalmente para o cadastramento de imóveis.

No que concerne à relação custo-beneficio do processo de construção de bases de dados, Aronoff (1995) comentou que há um balanço de interesses entre reduzir o grau de erro e o custo disso. O que importa, acrescentou o autor, é que o grau de erro deveria ser tal que não invalide a informação que o sistema disponibiliza.

Ainda com relação à discussão do uso direto de fotografias aéreas, é possível afirmar que, apesar das vantagens que esse método oferece, ele pode dificultar a união das fotografias pelos decalques correspondentes. Wolf (1983) afirmou que a construção de mosaicos é dificultada pelos deslocamentos das imagens e variações de escala das fotografias. Assim mesmo, existem vários métodos para se realizar esta tarefa: por triangulação radial gráfica (Wolf, 1983; Barros et al., 1987); pela utilização de instrumentos de reflexão ou projeção (Baker et al., 1979; Wolf, 1983; Barros \& Cardoso, 1992; Campos et al., 1993; Warner et al., 1996).; ou mesmo pela união de arquivos vetoriais resultantes de digitalização. Os dois primeiros baseiam-se na união dos decalques sobre um mapa-base, geralmente uma carta planialtimétrica. Já, o último une arquivos vetoriais digitalizados separadamente, corrigidos satisfatoriamente por pontos de controle. Wolf (1983) ressaltou que a questão principal é dispor de pontos de controle comuns em fotografias adjacentes.

\subsection{Conversão de dados em geoprocessamento}

Uma vez disponíveis, os documentos originais podem ser convertidos para formato digital vetorial. Existem dois métodos mais usuais: via mesa digitalizadora e digitalização em tela. No primeiro, o documento é afixado sobre uma mesa, onde, por meio de um cursor, são transferidos os dados de coordenadas das feições digitalizadas para o computador. No outro, o documento é copiado por scanner e suas feições são digitalizadas diretamente em tela, de forma manual, pelo operador utilizando o cursor do 
computador. Quintanilha (1996) esclareceu que a digitalização em tela pode ser realizada ainda de forma semi-automática ou automática, quando esse processo é auxiliado por softwares que traçam as feições automaticamente ou semi.

Quintanilha (1996) afirmou que os casos indicados para a utilização do processo de digitalização via mesa são aqueles em que é inviável o uso de scanners, ou quando os originais são desenhos em formatos incomuns ou contenham muitas intersecções ou grande variedade de temas. Por sua vez, Oliveira et al. (1995) informaram que a eficiência de cada um varia com o tempo gasto, o custo, a precisão, a disponibilidade de equipamentos/programas e o documento a ser digitalizado.

A conversão dos dados via mesa exige, primeiramente, a definição do sistema de coordenadas com o qual se deseja trabalhar: num sistema arbitrário da própria mesa; no sistema de coordenadas do material que está sendo digitalizado; ou, então, num outro sistema de referência, como, por exemplo, o sistema de coordenadas planas UTM. Optando-se pela última alternativa, o programa requer a informação das coordenadas de alguns pontos, também denominadas coordenadas verdadeiras. Esses pontos são os chamados pontos de controle para digitalização, a partir dos quais o programa transforma as coordenadas arbitrárias da mesa em coordenadas do sistema escolhido. A transformação, na realidade, nada mais é do que uma solução matemática, cujas incógnitas são a mudança de escala, a rotação e a translação do sistema arbitrário de coordenadas da mesa (Wolf, 1983). Observa-se que, dentre algumas alternativas possíveis, o programa seleciona aquela combinação mais adequada. Simultaneamente, é realizado um ajuste para minimizar os erros. Assim, o documento fica georreferenciado pelo sistema escolhido.

Quintanilha (1996) argumentou que a calibração da mesa digitalizadora (transformação das coordenadas), a seleção dos pontos de controle para ajuste do documento e o georreferenciamento são práticas importantes, uma vez que erros de 
posição e de geometria podem ser introduridos apenas com pequenas modificações nesses dados, normalmente desconhecidos dos usuários em geral. Quanto à calibração, Oliveira et al. (1995) sugeriram não realizar essa prática várias vezes, por ser quase impossível chegar sempre às mesmas coordenadas dos pontos de controle.

Jones (1993) e Montgomery \& Shuch (1993) comentaram que a maioria dos programas possui uma forma simples de controle de qualidade, apresentado na forma de uma estimativa grosseira de exatidão antes do início da digitalização e depois. Essa estimativa não passa de uma análise estatística na forma do erro médio quadrático (RMS error - Root Mean Square error), que expressa o grau de variação entre as medidas de coordenadas do sistema da mesa e do sistema escolhido. Baseia-se na suposição de que os erros são ao acaso e, assim, serão distribuídos normalmente ao redor das coordenadas definidas como verdadeiras.

O RMS é, portanto, equivalente ao desvio padrão desta distribuição:

$$
\mathrm{RMS}=\sqrt{\frac{\sum(x-t)^{2}}{n-1}}
$$

onde: $x=$ medida da coordenada na direção de um dos eixos (x ou y) do sistema da mesa;

$t=$ medida da coordenada na direção do mesmo eixo acima, no sistema escolhido; $n=$ número de pontos de controle da digitalização.

O erro medido pelo RMS, segundo Jones (1993), provém da combinação dos seguintes fatores: coordenação visual-motora deficiente, inexatidão do documento original e imperfeita adequação do modelo linear para descrever a relação entre as 
coordenadas da mesa e as coordenadas do sistema de referência escolhido. Entretanto, o mesmo autor afirmou que isso vale apenas para casos em que os pontos de controle estão posicionados em locais com feições reais, tais como interseção de estradas. Nos outros casos, nos quais os pontos de controle representam somente interseções de grades usadas como referências, o RMS não reflete erros associados à qualidade dos dados do documento original.

Todavia, a questão principal é, conforme Jones (1993), determinar o grau de confiabilidade do RMS informado. Como exemplo, o autor cita um projeto que demanda uma exatidão de $2 \mathrm{~m}$. Se o RMS for calculado sobre um número grande de pontos de controle (30 pontos), então seu grau de confiabilidade será maior do que se for sobre um número pequeno (4 pontos), desde que o RMS esteja abaixo do limite permitido.

Por sua vez, Bracken \& Webster (1992) declararam que, no momento da transformação das coordenadas, os desvios medidos pelo RMS são corrigidos convenientemente. Assim, o documento estaria pronto para digitalização.

A digitalização via mesa é um processo lento e entediante. Além disso, causa fadiga, erros nos dados ou omissão (Montgomery \& Schuch, 1993; Aronoff, 1995). Entretanto, o equipamento é relativamente barato e o processo fácil de se aprender. Sua principal desvantagem é possuir exatidão limitada, uma vez que está presa à exatidão do documento original.

Existem vários fatores que interferem na qualidade da digitalização via mesa. Thapa \& Bossler (1992) apontaram os seguintes:

- espessura da linha;

- habilidade do operador; 
- complexidade da feição a ser digitalizada;

- resolução do cursor; e

- densidade de feições.

A densidade de feições torna a escala do documento um aspecto importante (Maffini, 1989). Já, Oliveira et al. (1995) informaram que os erros verificados durante a digitalização dizem respeito aos instrumentos, condições externas a essa prática e aspectos operacionais. $\mathrm{O}$ primeiro tipo de erros decorre de alguma impefeição, limitação ou ajustamento dos instrumentos utilizados; o segundo da luminosidade, posição do operador e disposição dos equipamentos na estação de trabalho inadequados; e o terceiro da inabilidade do operador e das limitações dos sentidos humanos, como a visão e o tato.

Após a digitalização, os arquivos vetoriais criados precisam ser editados. Esse processo corrige falhas que, segundo Burrough (1986), podem ser agrupadas em:

- dados espaciais estão incompletos ou repetidos;

- dados espaciais estão no local errado;

- dados espaciais estão na escala errada;

- dados espaciais são distorcidos;

- dados espaciais estão ligados a dados não espaciais errados; e

- dados não espaciais estão incompletos.

$\mathrm{Na}$ edição, muitas vezes, unem-se arquivos vetoriais digitalizados separadamente. Star \& Estes (1990) informaram que esse processo é dificultado por problemas, que são causados por: mudanças dos documentos pela temperatura e 
umidade; erros de georreferenciamento; extrapolações e aproximações ou "arredondamentos" (numerical round-off errors) nos algoritmos de georreferenciamento; erros de exatidão da própria mesa digitalizadora e problemas de sobreposição e lacunas entre documentos adjacentes.

Uma vez unidos, os arquivos vetoriais estão prontos para futuras manipulações. No entanto, Quintanilha (1996) recomendou para as manipulações a mudança da representação vetorial para a matricial. Burrough (1986), assim como Vettorazzi (1992), afirmaram que a representação vetorial, embora retrate melhor a realidade e possua uma estrutura de dados compacta, dificulta as análises espaciais. Por outro lado, a matricial é uma representação regular e, por esse motivo, facilita a sobreposição de mapas e as análises espaciais. Todavia, Quintanilha (1996) comentou que a representação matricial contém o problema de provocar erros nas estimativas das características geométricas e topológicas (áreas, perímetros etc) por estar baseada na discretização da realidade. Nesse sentido, Quintanilha (1996) extendeu suas explicações e indicou alguns fatores aos quais os parâmetros básicos a serem controlados na conversão vetor-matriz dizem respeito:

- complexidade do desenho;

- tamanho do elemento da imagem matricial gerada (pixel);

- método de conversão; e

- erros advindos da conversão.

Dentre esses, Burrough (1986) comentou sobre a perda de informação provocada pela conversão e acrescentou que a diminuição de exatidão é proporcional à discrepância (wiggliness) das linhas limítrofes e ao tamanho do pixel. Quanto ao último, o autor citou um exemplo mostrando que uma grade de $32 \times 32$ elementos (pixels) produz a metade de erros de discordância (mismatch) do que uma grade de $16 \times 16$ elementos. 
No que concerne à agregação de erros durante o processo de conversão de dados, Vitek et al., citados por Walsh et al. (1987), concluíram que a integração de dados provenientes de fontes, formatos (por exemplo: pontos, linhas e áreas) e em escalas diferentes, possuindo cada um deles erros inerentes, resulta num produto de exatidão questionável.

\subsection{Análise temporal em geoprocessamento}

A análise temporal em geoprocessamento consiste da comparação de dados de diversas épocas por meio da aplicação de métodos univariados e multivariados de análise estatística.

Ela e outros tipos de análise são muito facilitados, segundo Vettorazzi ${ }^{1}$, pela adoção de um modelo cartográfico, que nada mais é do que o uso de funções básicas de manipulação em sistemas de informações geográficas (SIG), numa sequência lógica, para resolver problemas espaciais complexos. Seu propósito é ajudar o analista a organizar e estruturar os procedimentos que serão usados em seu estudo e a identificar os dados necessários para completá-los.

Schlagel \& Newton (1996) afirmaram que o mapeamento de eventos cronológicos possui valor limitado, uma vez que é dificil interpretar visualmente um mapa que represente dados multitemporais. Assim, ao invés de apresentar os dados num único mapa, a dimensão temporal dos dados é, freqüentemente, resumida ou alguns dados são mesmo eliminados. Os autores, apresentando uma revisão dos diversos métodos de análise multitemporal, informaram que o método mais comum de examinar mudanças é sobrepor mapas que representam a distribuição espacial de uma variável de interesse em dois períodos de tempo diferentes. Os resultados da sobreposição são facilmente tanto representados num mapa como interpretados visualmente. Um exemplo desse método

\footnotetext{
${ }^{1}$ VETTORAZZI, C.A. Modelagem cartográfica. Anotações de aula. 1997.
} 
pode ser encontrado em Lo \& Shipman (1990). Esses autores analisaram as mudanças de uso da terra no desenvolvimento de uma nova cidade. Eles utilizaram técnicas de sobreposição de imagens e máscara binária para detectar a dinâmica das mudanças. A análise foi feita pelo software Idrisi em formato matricial. Os resultados foram apresentados na forma de tabelas cruzadas. Os autores perceberam que as técnicas usadas - com uma exatidão correspondente à metade do tamanho de um pixel - mostraram-se particularmente úteis na quantificação da dinâmica das mudanças em cada categoria, o que era impossível de ser realizado pelas técnicas convencionais.

Outro exemplo expressivo nesta área é o trabalho de Adeniyi (1980). Já naquela época, o autor conseguiu quantificar as mudanças no uso da terra de forma dinâmica entre as datas de 1962 e 1974. Ele dividiu os mapas em quadrículas de $100 \mathrm{~m} \mathrm{x}$ $100 \mathrm{~m}(1 \mathrm{ha})$, referenciou-as por coordenadas $\mathrm{x}$ e y e deu-lhes um código, segundo o seu tipo de uso da terra. Utilizando programas de computador desenvolvidos em linguagem Fortran, calculou a área ocupada por cada tipo de uso da terra nas diferentes datas. Além disso, estimou a magnitude e o tipo de mudança, apresentando os resultados na forma de tabelas cruzadas, identificou o local onde elas ocorreram e ilustrou, por meio de mapas, os padrões tanto dos diferentes tipos de uso da terra como de distribuição das mudanças.

Ainda, Silva et al. (1993) analisaram temporalmente o uso da terra em Ubajara (CE), utilizando fotografias aéreas de 1958, imagem do sensor TM/Landsat-5 de 1985 e o software Erdas. Os autores deduziram que a análise foi útil para a visualização das variações espaciais e temporais de uso da terra e aperfeiçoou o armazenamento e a manipulação de dados.

Schlagel \& Newton (1996), no entanto, declararam que, quando a análise abrange mais de dois períodos de tempo, o emprego de técnicas de sobreposição torna-se mais complicado. Ou seja, apesar de um sistema de informações geográficas ser capaz de sobrepor mapas que representam dados de várias datas, a apresentação desses resultados num único mapa pode ser muito complexa para sua interpretação visual. 
Uma alternativa para representar dados de várias datas num único mapa é resumir estatisticamente a série de dados temporais. Calkins \& Dickinson (1987), citados por Langran (1993), recomendaram a adaptação de métodos estatísticos de exploração de dados para visualizar e identificar dados e padrões espaço-temporais, seus processos analíticos e os resultados. Schlagel \& Newton (1996) informaram que a análise pode ser feita por programas de análise estatística vinculáveis ao SIG ou existentes no próprio SIG. No último caso, a análise estatística de séries temporais pode ser realizada por meio da análise de componentes principais, análise de regressão, por meio de funções matemáticas aplicadas aos mapas, ou ainda pela tabulação cruzada. Um exemplo de aplicação dessa última função é o trabalho de Moraes et al. (1993), que avaliaram e quantificaram a mudança ocorrida no uso da terra da microbacia do Rio Campo do Tenente, região sudeste do Estado do Paraná. Eles utilizaram fotografias aéreas dos anos de 1952 e 1980, levantamento de campo em 1990 e o software SGI/INPE. Empregaram o aplicativo do SGI denominado "tabulação cruzada e cálculo de área" para o estabelecimento das relações solo/uso da terra nas três épocas distintas. Os autores concluíram que a metodologia empregada viabilizou a dinâmica e acompanhamento do uso da terra, bem como a quantificação de cada solo existente na área, com a respectiva categoria de uso.

\subsection{Estudos de análise temporal do uso da terra por meio de técnicas de geoprocessamento}

A adição do componente temporal aos estudos de análise do uso da terra possibilita não apenas armazenar o histórico de estados passados, mas também examinar o mundo como um grande reservatório de entidades dinâmicas, interrelacionadas por processos que funcionam como catalisadores de mudanças. Em qualquer processo observado, sua inclusão nos dados representa as mudanças e a derivação de relacionamentos de causa e efeito. 
As mudanças no mundo real, muitas vezes, ocorrem em ciclos e têm uma importância fundamental para o entendimento dos processos ambientais. Comparando-se uma configuração de entidades específicas de um sistema com seus estados antigos é possível identificar o que foi modificado e, a partir daí, tentar descobrir as razões dessa mudança.

Assim, os processos ambientais são estudados pela observação empírica de seus efeitos sobre as entidades. Uma vez estabelecida uma hipótese, baseada em acontecimentos passados, para explicar alguns fenômenos atuais, ela é usada para prever as possibilidades de ocorrência desse ou de outros fenômenos no futuro. Quanto mais a hipótese é validada ao longo do tempo, maior é a sua credibilidade e, portanto, é maior a sua eficiência na previsão de eventos futuros (Medeiros \& Botelho, 1996).

Usando essa concepção na forma de uma análise geográfica seqüencial (AGS, desenvolvida por Hamshere (1987) e Sebastiniani (1989)), que é o estudo de qualquer período passado para o qual uma seqüência de atividades humanas, mais ou menos detalhada, é estabelecida, Bertolami (1997) estudou retrospectivamente o impacto do uso sobre as terras de uma bacia hidrográfica, no Estado de São Paulo.

Medeiros \& Botelho (1996), extendendo suas explanações, apontaram algumas aplicações de SIGs temporais em administração de recursos naturais e controle ambiental:

- gerenciamento florestal;

- planejamento urbano;

- controle ecológico de regiões;

- gerenciamento agrícola;

- entre outras. 
Dentre outras, é possível mencionar a análise temporal do uso das terras de uma região visando seu planejamento. Diversos enfoques têm sido adotados nos trabalhos relacionados a esse tema. Um deles analisa o uso das terras em diferentes datas, conforme a dinâmica de ocupação, as perdas de solo estimadas e/ou a adequação de uso, além das variações nas características da rede de drenagem.

Assim, Bertolami (1997), em seu trabalho, elaborou um método de planejamento do uso da terra, utilizando dados de impacto cumulativo, uso atual e capacidade de uso de uma bacia hidrográfica predominantemente canavieira no Município de Rio Claro, SP. Foram utilizadas as fotografias aéreas convencionais de 1962, 1972, 1978, a carta de uso do solo da bacia do Ribeirão Claro em 1990, imagem TM/Landsat-5 de 1996 e o software Idrisi para Windows versão 2.0. Os impactos cumulativos foram mensurados por meio da somatória de índices que representam a intensidade de perda de solo estimada pela equação universal de perdas de solo (EUPS) em cinco datas. $\mathrm{O}$ autor concluiu que o método, levando em conta os processos erosivos, mostrou-se útil, embora deva contemplar as limitações dos modelos de estimativa de perda de solo empregados e as diferentes alternativas oferecidas, sejam essas referentes à adequação do uso da terra, às condições ambientais ou às possíveis variações de manejo das agropaisagens e propriedades.

Já, Fiorio (1998) avaliou a cronologia do uso da terra em quatro datas, o grau de erosão dos solos ocupados e o impacto das ações antrópicas na microbacia hidrográfica do Córrego do Ceveiro, localizada no Município de Piracicaba, SP. Ele utilizou as fotografias aéreas convencionais de 1962, 1965, 1978 e 1995, bem como o software Idrisi e a EUPS para estimar as perdas de solo nas diferentes datas. $\mathbf{O}$ autor observou que a maior parte da microbacia apresentava em 1995 áreas acima dos níveis de tolerância de perdas de solo. Também notou que, em geral, no período estudado, houve uma diminuição das áreas com perdas 10 vezes maior que a tolerada e um aumento das com 5 a 10 vezes a tolerada, o que pode ser creditado, principalmente, à expansão da cultura canavieira. 
Angulo Filho (1981) estudou as variações das características de redes de drenagem entre 1940 e 1978, em amostras circulares da região de Piracicaba. O autor utilizou as fotografias aéreas de 1940, 1962, 1972 e 1978. Uma de suas conclusões foi que a lavoura canavieira completou a ocupação dos solos latossólicos por volta de 1962, enquanto que a ocupação dos solos podzólicos só ocorreu por volta de 1978. Além disso, o autor verificou que as cabeceiras das redes de drenagem, nos latossolos, eram mais protegidas antes da instalação definitiva, a partir de 1950, da agroindústria canavieira.

Também Vasconcelos et al. (1991) avaliaram as variações nas características da rede de drenagem da bacia do Rio Araquazinho, Município de São Manuel, SP, por meio do uso das fotografias aéreas de 1962 e 1979. Os autores objetivaram analisar a influência das mudanças da ocupação do solo sobre o processo evolutivo da erosão na bacia, localizada em região de intensa atividade agroindustrial canavieira. Os autores constataram que a expansão da cultura da cana-de-açúcar, mais tecnificada, resultou numa situação de melhor preservação da rede drenagem, por causa do aterramento de sulcos de erosão estabilizada, localizados em posição não característica de calha.

Por outro lado, Ranieri \& Sparovek (1993) estudaram a evolução dos usos das terras do Município de Piracicaba, SP, utilizando como fontes de dados fotografias aéreas convencionais de 1962 e imagem TM/Landsat-5 de 1991. As informações foram digitalizadas e gerenciadas pelo programa Gmap, desenvolvido pelo Departamento de Ciências do Solo da Escola Superior de Agricultura "Luiz de Queiroz" (ESALQ), da Universidade de São Paulo (USP). Os resultados mostraram que as áreas ocupadas com cana-de-açúcar aumentaram consideravelmente de 1962 para 1991 (35,4\% para $49,3 \%$ da área total do município). O contrário foi observado para as pastagens, cuja área decresceu de $42,8 \%$ para $25,9 \%$, no mesmo período. Os mesmos autores observaram também que o avanço da cana-de-açúcar aconteceu predominantemente sobre as áreas de pastagens ( $13,6 \%$ da área total do município). Ainda, uma grande área com cana-de-açúcar permaneceu com essa cultura (26,6\%). Já, as áreas anteriormente 
com pastagens que permaneceram com essa ocupação somaram 18\%. Quanto à vegetação natural, os autores observaram que em 1962 ocupava 13,6\% do total do município e em 1991 17\%. A categoria cedeu 5,4\% da área total para cana-de-açúcar e $3,5 \%$ para pasto no período estudado. Além disso, afirmaram que as áreas com vegetação natural, em quase sua totalidade, compreendiam as matas ciliares que restavam no município e um pequeno número de fragmentos florestais. Os autores concluíram que o avanço da cana-de-açúcar, na região, pode ser atribuído ao incentivo governamental para essa cultura, durante a década de 70 e início dos anos 80. Por fim, eles acreditavam que, provavelmente, as áreas ocupadas com cana-de-açúcar não expandiriam, visto que as terras que estavam em 1991 sob pastagens foram consideradas marginais.

Borges et al. (1993) desenvolveram estudo similar na região canavieira de Santa Bárbara d'Oeste, SP, numa área de 14625 ha, com o intuito de analisar as tendências de ocupação do solo e os processos que se desenvolveram na região. Utilizaram fotografias aéreas convencionais de 1978 e imagem TM/Landsat-5 de 1991 como fontes de dados. A área de estudo foi dividida em células quadradas de $500 \mathrm{~m}^{2} \mathrm{e}$ cada uma delas foi identificada conforme o tipo de ocupação predominante. Posteriormente, as células referentes a cada categoria foram contadas e assim foram obtidas as áreas para cada tipo de uso. A área cultivada com cana-de-açúcar permaneceu praticamente constante no período $(66,8 \%$ da área total de estudo em 1978 e 66,0\% em 1991). A área de pastagem decresceu de 10,2\% para 5,5\%, fenômeno decorrente da expansão urbana. Os autores alertaram para a necessidade de aplicação de práticas intensivas de conservação dos solos nas áreas de cana-de-açúcar, uma vez que as terras da área de estudo, em sua grande maioria, estão enquadradas na classe IV de capacidade de uso.

Já Fiorio (1998), em seu trabalho, verificou uma redução drástica na área ocupada por culturas anuais (de 42,00\% em 1965 para 0,15\% em 1995). Em contrapartida, a área de cana-de-açúcar saltou de $16,00 \%$ para $66,00 \%$ no mesmo período. O maior crescimento das áreas de cana-de-açúcar deu-se entre os anos de 1978 
e 1995 , chegando a ocupar $40,00 \%$ da microbacia. A expansão da cultura de cana-deaçúcar foi maior sobre terras com classe de declividade de $10 \%$ a $20 \%$, seguida de $5 \%$ a $10 \%$ e $0 \%$ a $2 \%$. Ela ocorreu, principalmente, sobre solos podzólicos, mas sobre litólicos também foi importante. Em geral, as duas categorias que cederam mais áreas para canade açúcar foram cultura anual de 1965 a 1978 (solos litólicos, seguidos de podzólicos e classes de declividade 5\% a 10\% e 10\% a 20\%) e pasto de 1978 a 1995.

Muramoto et al. (1993) diagnosticaram a adequação de uso das terras do Município de Piracicaba em 1962 e 1991 por meio de critérios definidos pelo Departamento de Ciências do Solo da ESALQ, utilizando os mesmos dados de uso da terra obtidos por Ranieri \& Sparovek (1993) e os de capacidade de uso obtidos pelo cruzamento de dados de solo e declividade. Os resultados mostraram que em $196260 \%$ das terras do município eram adequadamente utilizadas e $20 \%$ inadequadamente $(16 \%$ com risco e $4 \%$ superutilizadas). Em 1991, 61\% das terras tinham uso adequado e $27 \%$ inadequado ( $19 \%$ com risco e $8 \%$ superutilizadas). As terras subutilizadas passaram de $14 \%$ para $7 \%$ no mesmo período. Os autores explicaram que estas alterações podem ser atribuídas principalmente à expansão da cultura canavieira sobre terras não apropriadas ao seu cultivo, fato ocorrido, em grande parte, devido à preocupação em se plantar o mais perto possível das unidades transformadoras.

Por sua vez, Sparovek \& Lepsch (1995), utilizando os mesmos dados de Ranieri \& Sparovek (1993) e de Muramoto et al. (1993), elucidaram que o avanço da cultura canavieira foi direcionado para áreas de menor aptidão agrícola porque quase a totalidade das áreas "nobres", de boa aptidão para lavouras, já era ocupada por canaviais desde 1962. Entretanto, a expansão da cana-de-açúcar não foi uniforme em toda área, concentrando-se principalmente nas vizinhanças das unidades processadoras. Além disso, os autores argumentaram que a expansão da cultura canaviera para áreas de menor aptidão agrícola, anteriormente ocupadas com pastagens, é o fator condicionante mais importante da degradação potencial das terras de Piracicaba. 
Ainda, Sparovek \& Lepsch (1998), ao analisar separadamente o uso das terras de Piracicaba por microbacia, apresentaram os resultados contidos nas Tabelas $1 \mathrm{e}$ 2 para a microbacia hidrográfica do Ribeirão Pau d'Alhinho. Os autores comentaram que a cultura da cana-de-açúcar já predominava na microbacia em 1962 devido às características topográficas da área e sua proximidade às unidades processadoras, apesar do predomínio de solos de baixa aptidão para cultivo intensivo. Ainda, argumentaram que a expansão da cana-de-açúcar, de 1962 para 1991, provocou um aumento das áreas com potencial de degradação.

Tabela 1. Uso da terra da microbacia hidrográfica do Ribeirão Pau d'Alhinho.

\begin{tabular}{|c|c|c|c|c|}
\hline \multirow{2}{*}{ Tipos de uso da terra } & \multicolumn{2}{|c|}{1962} & \multicolumn{2}{c|}{1991} \\
\cline { 2 - 5 } & Hectares & $\%$ & Hectares & $\%$ \\
\hline cana-de-açúcar & 706 & 47,45 & 1019 & 68,48 \\
\hline pastagem & 313 & 21,03 & 156 & 10,48 \\
\hline lavoura não canavieira & 69 & 4,64 & 94 & 6,32 \\
\hline reflorestamento & 94 & 6,32 & 0 & 0 \\
\hline vegetação natural & 306 & 20,56 & 219 & 14,72 \\
\hline Total & 1488 & 100,00 & 1488 & 100,00 \\
\hline
\end{tabular}

Fonte: Sparovek \& Lepsch (1998)

Tabela 2. Adequação de uso da terra da microbacia hidrográfica do Ribeirão Pau d'Alhinho.

\begin{tabular}{|c|c|c|c|c|}
\hline \multirow{2}{*}{$\begin{array}{c}\text { Adequação de } \\
\text { uso da terra }\end{array}$} & \multicolumn{2}{|c|}{1962} & \multicolumn{2}{c|}{1991} \\
\cline { 2 - 5 } & Hectares & $\%$ & Hectares & $\%$ \\
\hline Adequado & 863 & 58,00 & 637 & 42,84 \\
\hline Subutilizado & 81 & 5,44 & 31 & 2,08 \\
\hline Risco & 519 & 34,88 & 756 & 50,84 \\
\hline Superutilizado & 25 & 1,68 & 63 & 4,24 \\
\hline Outros & 0 & 0 & 0 & 0 \\
\hline Total & 1488 & 100,00 & 1487 & 100,00 \\
\hline
\end{tabular}

Fonte: Sparovek \& Lepsch (1998) 


\section{MATERIAL E MÉTODOS}

\subsection{Material}

\subsection{1 Área de estudo}

Para este trabalho foi selecionada como área de estudo a microbacia hidrográfica do Ribeirão Pau d'Alhinho, localizada no Município de Piracicaba, Estado de São Paulo, aproximadamente entre as longitudes $46^{\circ} 43^{\prime}$ W e $47^{\circ} 44^{\prime}$ W e as latitudes $22^{\circ} 41^{\prime} \mathrm{S}$ e $22^{\circ} 46^{\prime} \mathrm{S}$, com uma área aproximada de 1505 ha. À sua volta existe um número considerável de usinas canavieiras. A Figura 1 apresenta a área de estudo em destaque e também sua proximidade com a área urbana de Piracicaba.

O Ribeirão Pau d'Alhinho é afluente direto do Rio Piracicaba e tem como principal formador o Córrego Barro Preto.

A região onde se encontra a microbacia apresenta clima do tipo Cwa, de acordo com a classificação de Köppen, isto é, mesófilo úmido, sub-tropical com inverno seco e temperatura do mês mais quente superior a $22^{\circ} \mathrm{C}$.

As unidades de solo que ocorrem na área, de acordo com Sparovek \& Lepsch (1998), cuja distribuição pode ser visualizada na Tabela 3 e Figura 2, que foi obtida após a digitalização da carta de solos (Oliveira et al., 1989), são: 


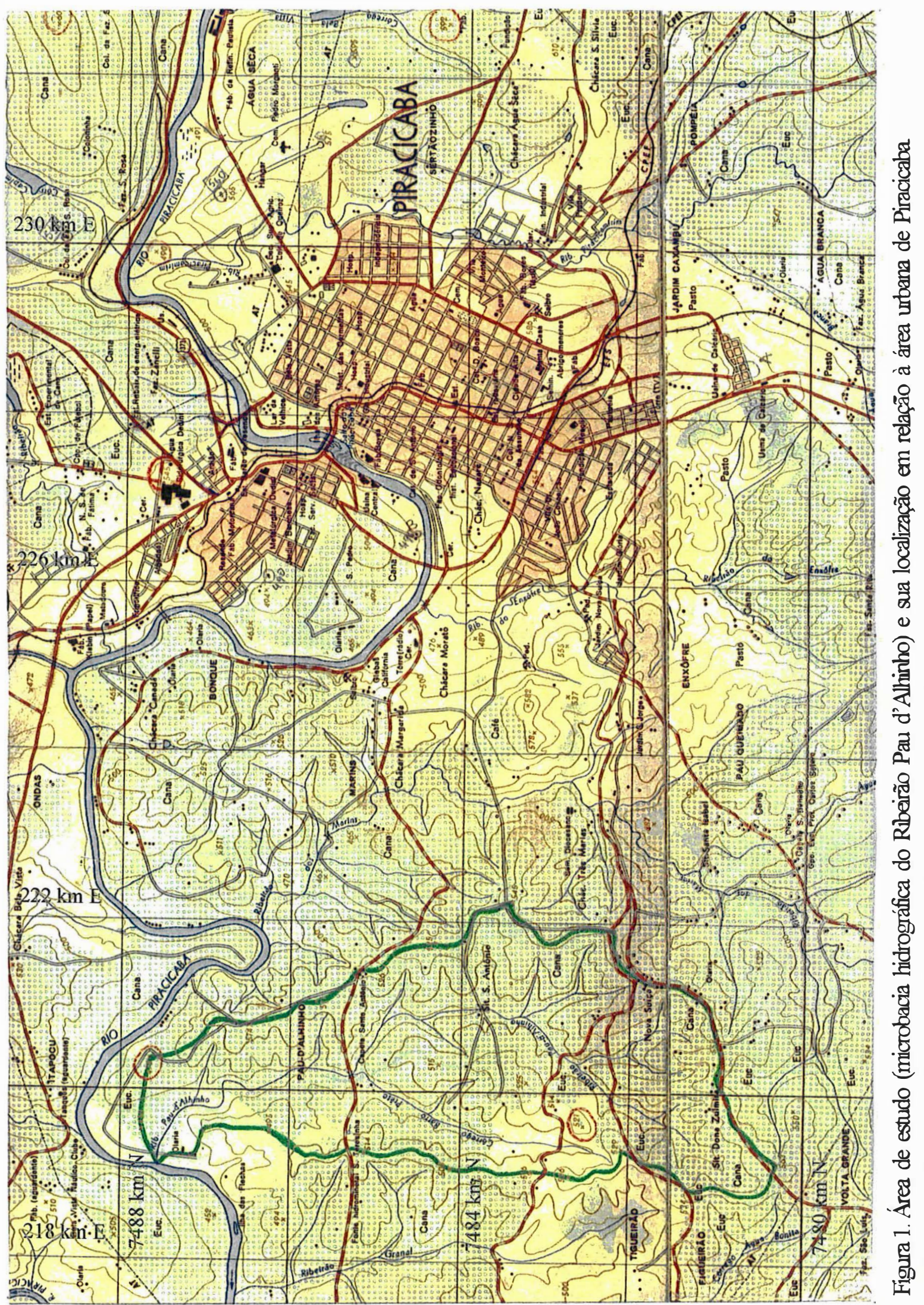




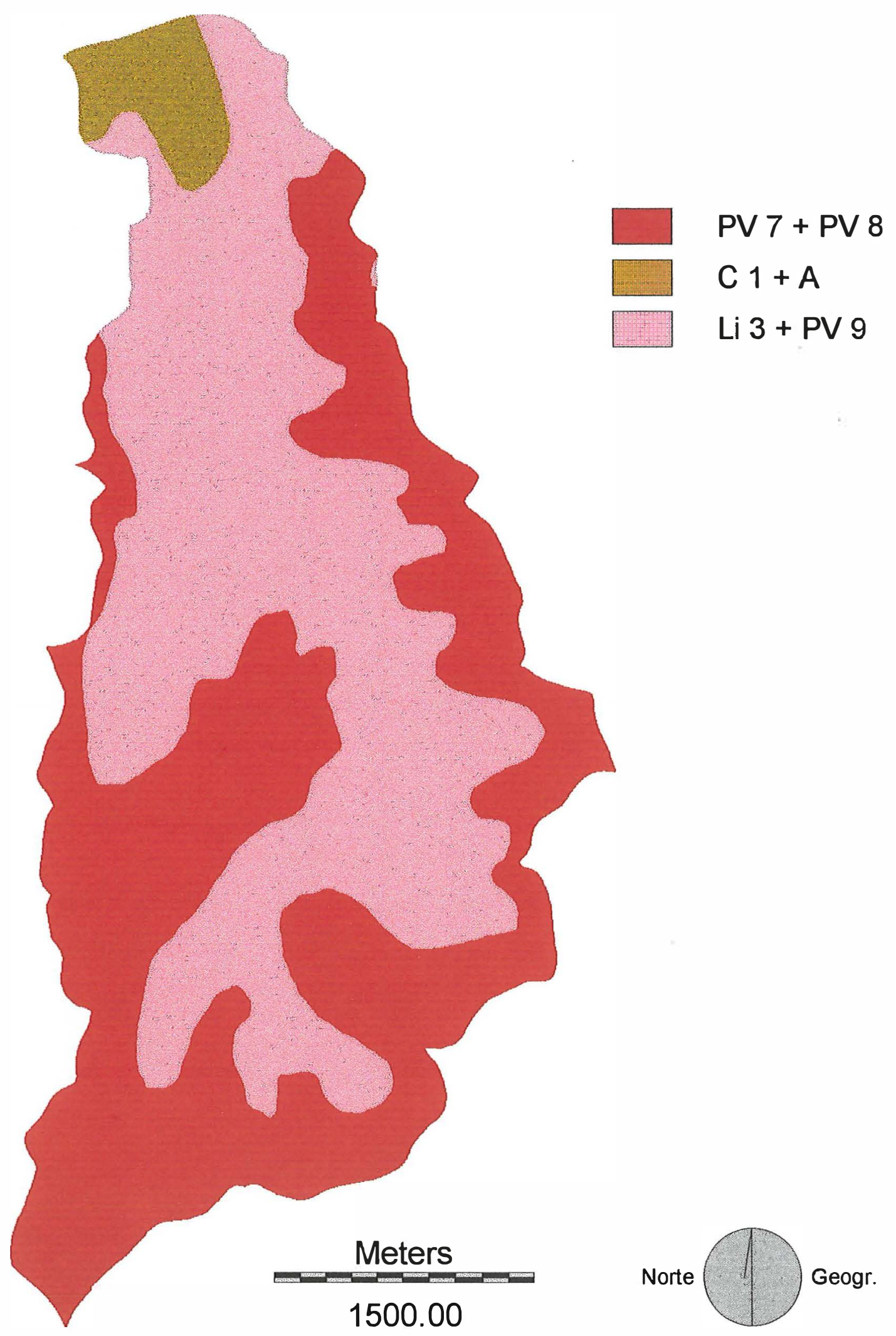

Figura 3. Unidades de solo da microbacia hidrográfica do Ribeirão Pau d'Alhinho. 
- associação de solos podzólicos (PV 7 + PV 8)

PV 7: Grupamento indiscriminado de POZÓLICOS VERMELHO-AMARELOS abruptos, A moderado e espesso, textura arenosa/média. Unidade Serrinha;

PV 8: Grupamento indiscriminado de PODZÓLICOS VERMELHO-AMARELOS abruptos, A moderado e espesso, textura arenosa/média poucos profundos. Unidade Serrinha fase pouco profunda;

- associação de solo cambissolo com solo aluvial (C 1 + A)

C 1: CAMBISSOLO ÁLICO Tb, A moderado e espesso, textura indiscriminada, bem imperfeitamente drenado. Unidade Sete Lagoas;

A: Grupamento indiscriminado de SOLOS ALUVIAIS;

- associação de solo litólico com solo podzólico (Li 3 + PV 9)

Li 3: SOLOS LITÓLICOS EUTRÓFICOS OU DISTRÓFICOS, A moderado, proeminente ou chernozênico, substrato sedimento indiscriminado do Grupo Passa Dois;

PV 9: Grupamento indiscriminado de PODZÓLICOS VERMELHO-AMARELOS Tb abruptos, A moderado, textura arenosa/argilosa ou média/argilosa. Unidade Santa Cruz.

Tabela 3. Áreas das unidades de solo da microbacia.

\begin{tabular}{|c|c|c|}
\hline Unidades de solo & Hectares & $\%$ \\
\hline asociação de solos podzólicos & 531,00 & 36,42 \\
\hline associação de solo cambissolo com solo aluvial & 63,00 & 4,32 \\
\hline associação de solo litólico com solo podzólico & 864,00 & 59,26 \\
\hline Total & 1458,00 & 100,00 \\
\hline
\end{tabular}

Fonte: Sparovek \& Lepsch (1998) 
Sparovek \& Lepsch (1998) constataram que, nas partes mais elevadas da microbacia em direção aos divisores de água, predominam os solos com gradiente textural elevado e encontraram solos rasos próximos à rede de drenagem.

O relevo da microbacia é, em geral, ondulado, com uma declividade média de $12 \%$. A altitude varia de $460 \mathrm{~m}$ a $565 \mathrm{~m}$. Segundo Sparovek \& Lepsch (1998), a microbacia ainda é constituída pelas classes de declividade apresentadas na Tabela 4.

Tabela 4. Áreas das classes de declividade da microbacia.

\begin{tabular}{|c|c|c|}
\hline Classes de declividade & Hectares & $\%$ \\
\hline $0-2 \%$ & 62,00 & 4,17 \\
\hline $2-5 \%$ & 88,00 & 5,92 \\
\hline $5-10 \%$ & 856,00 & 57,57 \\
\hline $10-15 \%$ & 481,00 & 32,35 \\
\hline$>15 \%$ & 0 & 0,00 \\
\hline Total & 1487,00 & 100,00 \\
\hline
\end{tabular}

Fonte: Sparovek \& Lepsch (1998)

Os tipos de terra predominantes da microbacia, conforme Flores (1995) e Koffler \& Moretti (1991), são altamente susceptíveis à erosão e, geralmente, quando estão associados a relevos ondulados são indicados para pastagens, reflorestamento e preservação. Eles necessitam de práticas complexas de conservação do solo ou dificultam a utilização da maior parte das máquinas agrícolas. Além disso, possuem, em grande parte, segundo Sparovek e Lepsch (1998), classe de capacidade de uso IV que, conforme Lepsch (1983), permite o cultivo apenas ocasional ou em extensão limitada, com sérios problemas de conservação.

Por fim, na área de estudo, predominam pequenas e médias propriedades que, em sua maioria, são utilizadas para o cultivo (próprio ou arrendado) de cana-deaçúcar. 


\subsubsection{Material cartográfico}

- Cartas planialtimétricas do Plano Cartográfico do Estado de São Paulo, folhas 071/088 (Santa Terezinha do Piracicaba), 072/088 (Bairro dos Marins) e 073/088 (Bairro Volta Grande), Governo do Estado de São Paulo, Secretaria de Economia e Planejamento, Coordenadoria de Ação Regional, Divisão de Geografia, $1^{\underline{a}}$ edição, $1978(073 / 088)$ e $1979(071 / 088$ e $072 / 088)$, escala 1:10.000;

- Carta pedológica semi-detalhada do Estado de São Paulo, folha de Piracicaba, Plano Cartográfico do Estado de São Paulo, Secretaria de Agricultura e Abastecimento, Coordenadoria de Pesquisa Agropecuária, Instituto Agronômico de Campinas e Secretaria de Economia e Planejamento, Coordenadoria de Ação Regional, Instituto Geográfico e Cartográfico, $1^{\underline{a}}$ edição, 1989, escala 1:100.000.

\subsubsection{Fotografias aéreas}

- 1940 - obtidas do acervo do Departamento de Engenharia Rural da Escola Superior de Agricultura 'Luiz de Queiroz"/USP.
a) escala aproximada: 1:20.000;
b) formato: $18 \mathrm{~cm} \mathrm{x} 18 \mathrm{~cm}$;
c) área coberta por fotografia: cerca de $12,96 \mathrm{~km}^{2}$;
d) identificação das fotografias: $\mathrm{n}^{\text {os }} 41,42,43,44,45,64$ e 66 .

- 1962 - obtidas do acervo da Seção de Fotointerpretação do Centro de Solos e Recursos Agroambientais do Instituto Agronômico de Campinas.

a) vôo realizado por Cruzeiro do Sul, Prospec S.A.- Geofoto S.A. para o Instituto Agronômico de Campinas da Secretaria de Agricultura do Estado de São Paulo; 
b) escala aproximada: 1:25.000;

c) formato: $23 \mathrm{~cm} \mathrm{x} 23 \mathrm{~cm}$;

d) área coberta por fotografia: cerca de $33 \mathrm{~km}^{2}$;

e) identificação das fotografias: $\mathrm{n}^{\text {os }}$ 9594, 9595 e 9596.

- 1978 - obtidas do acervo da Seção de Topografia do Departamento de Engenharia Rural da Escola Superior de Agricultura “Luiz de Queiroz"/USP.

a) vôo realizado por Terrafoto Atividades de Aerolevantamentos S.A. para a Secretaria de Economia e Planejamento do Estado de São Paulo (SEPLAN).

b) escala aproximada: 1:35.000;

c) formato: $23 \mathrm{~cm} \mathrm{x} 23 \mathrm{~cm}$;

d) área coberta por fotografia: cerca de $64,8 \mathrm{~km}^{2}$;

e) identificação das fotografias: faixa $15, n^{0}$ 2903, 19/06/1978 e faixa $16, \mathrm{n}^{\mathrm{o}} 2964$, 25/06/1978.

- 1995 - obtidas do acervo da Prefeitura do Campus da USP em Piracicaba.

a) vôo realizado por Base S.A. para o Serviço Municipal de Águas e Esgoto de Piracicaba (SEMAE);

b) escala aproximada: 1:25.000;

c) formato: $23 \mathrm{~cm} \mathrm{x} 23 \mathrm{~cm}$;

d) área coberta por fotografia: cerca de $33 \mathrm{~km}^{2}$;

e) identificação das fotografias: 0-576, faixa 14, nos 13, 14 e 15, junho de 1995 .

\subsubsection{Material para fotointerpretação}

- estereoscópio de espelhos da marca Wild, modelo ST-4; 
- folhas de poliéster transparente;

- material de desenho: lapiseira, grafites coloridas, borracha, lápis-borracha;

- aerosketchmaster Zeiss - Aerotopograph München.

\subsubsection{Equipamentos de informática e softwares}

- PC $486 \mathrm{DX} 4,32 \mathrm{Mb}, 100 \mathrm{Mhz}$ e PC $486 \mathrm{DX} 2,8 \mathrm{Mb}, 66 \mathrm{Mhz}$;

- mesa digitalizadora Summagraphics Microgrid III;

- software Tosca versão 2.03 (Clark University, 1993);

- software Idrisi para Windows versão 2.0 (Clark University, 1997);

- software Excel para Windows versão 5.0.

\subsection{Métodos}

\subsubsection{Escolha da área de estudo}

A escolha da área de estudo foi baseada:

a) na sua proximidade à Piracicaba - o que facilitaria idas ao campo;

b) na disponibilidade das fotografias áreas;

c) na sua dimensão, apropriada para o tipo de estudo;

d) na importância da bacia do Rio Piracicaba, em cujas águas desembocam as do Ribeirão Pau d'Alhinho, que está localizada numa área de alta concentração de indústrias, com maior potencial de degradação ambiental, gerando uma economia muita ativa e, portanto, de grande interesse;

e) na colaboração ao desenvolvimento de projetos que estão sendo realizados na região, precursora de estudos ambientais;

f) no histórico de uso da terra, pois a região é ocupada desde antes de 1940. 


\subsubsection{Levantamento e preparação dos dados}

\subsubsection{Fotointerpretação e definição da legenda}

Depois de selecionadas as fotografias aéreas da área de estudo, fez-se um levantamento de reconhecimento geral dos alvos nas próprias fotografias. Essa identificação genérica propiciou a escolha preliminar das categorias de uso da terra que fariam parte da chave de interpretação e da legenda.

As características dos elementos de reconhecimento (textura, porte, tonalidade e aspectos associados) das categorias de uso da terra visualizadas no estudo preliminar foram comparadas às encontradas por Audi (1965), Koffler et al. (1979), Borges et al. (1993) e Fiorio (1998) e, no final, definiu-se a chave de interpretação.

A seguir, as fotografias foram interpretadas com o auxílio de um estereoscópio de espelhos, seguindo o procedimento convencional de fotointerpretação. Procurou-se identificar tudo que era visível e possível, por menor que fosse o alvo, recorrendo-se à chave de interpretação quando necessário.

As informações foram extraídas, sobretudo, da porção central de cada fotografia (área útil), onde as distôrções geométricas são menores.

Ressalta-se que a área fotointerpretada foi além dos limites da microbacia selecionada, porque não seria possível garantir que os mesmos fossem estabelecidos exatamente coincidentes nas imagens das quatro datas diferentes usadas.

O processo de fotointerpretação foi feito de forma retroativa, conforme Bertolami (1997), ou seja, iniciou-se com o ano de 1995. Isto porque, havendo a possibilidade de checar seus resultados em campo, pela observação e entrevistas com os

proprietários, a fotointepretação para 1995 pôde ser considerada isenta de erros. Assim, a 
confirmação das características específicas dos diferentes alvos associada a essa verificação em campo, conferiu também maior confiabilidade na identificação de alvos nos demais anos.

O resultado dessa fotointerpretação foi registrado em folhas de poliéster transparente colocado sobre as fotografias.

Nos casos de dúvida quanto à identificação de determinados alvos, recorreu-se ao auxílio de fotointérpretes mais experientes.

A legenda foi definida após a fotointerpretação.

\subsubsection{Preparação do material a ser digitalizado}

Nos decalques de uso da terra, ainda sobrepostos às fotografias aéreas, foram demarcados pontos visíveis tanto nas fotografias como nas cartas planialtimétricas e dos quais se poderia conhecer suas coordenadas a partir das cartas (pontos de controle para correção geométrica). Assim, confluências de estradas, estradas com rios, entre outros, foram preferidos e marcados.

Nas datas correspondentes aos anos mais recentes (1995, 1978 e 1962), a escolha dos pontos foi feita somente com base na visualização direta das fotografias e cartas. Já nas fotografias de 1940, a demarcação dos pontos foi realizada com auxílio do aparelho aerosketchmaster, que fez com que pontos selecionados e localizados nas cartas planialtimétricas pudessem ser demarcados nas fotografias.

O processo de escolha ainda levou em conta que os pontos deveriam ser demarcados de forma aproximadamente eqüidistante, mas que se localizassem principalmente tanto dentro como próximos aos limites da área de estudo. Esse procedimento justificou-se na crença de que dessa forma haveria maior exatidão 
conforme Farret (1996 e 1997). Além disso, procurou-se eleger pontos comuns a dois decalques adjacentes.

As coordenadas dos pontos de controle foram extraídas das cartas planialtimétricas da seguinte forma: as cartas foram colocadas sobre a mesa onde, após sua calibração, o software Tosca (Jones, 1993) foi usado para digitalização dos pontos, formando-se os arquivos das coordenadas dos pontos de controle. Daí, aplicou-se a função vecedit do Tosca e anotou-se os seus valores. Haveria também a possibilidade de se obter as coordenadas medindo-as diretamente nas cartas, por exemplo com régua. No entanto, além de mais trabalhoso, esse processo é menos acurado.

O levantamento das coordenadas dos pontos de controle com as técnicas adotadas apresenta a grande vantagem de permitir a execução do trabalho em escritório.

Já para a calibração da mesa, necessária para a digitalização das cartas planialtimétricas e de solos, foram empregados pontos referentes à intersecção das linhas definidoras das quadrículas do sistema de coordenadas.

Uma vez que, nesse estudo, assumiu-se um nível de exatidão baseado nos padrões norte-americanos para o controle de qualidade da digitalização, foi necessária a realização de uma triagem dos pontos usados na transformação de coordenadas, de tal forma que eles apresentassem, em conjunto, um erro médio quadrático aceitável. Esse procedimento foi adotado, principalmente, para que facilitasse a união entre documentos adjacentes e permitisse a elaboração de documentos mais confiáveis.

Segundo Jones (1993), de acordo com a revisão de 1947 dos Padrões Nacionais Norte-americanos para Exatidão de Mapas (United States National Map Accuracy Standards), os mapas não devem ter mais de 10\% dos pontos testados para verificação de erro com um afastamento de $1 / 30$ de polegada para mapas na escala 1 : 
20.000 ou menores e não mais de 1/50 de polegada para mapas com escalas maiores que $1: 20.000$.

Ainda conforme Jones (1993), a conversão dos padrões de exatidão do erro médio quadrático aceitável em análise estatística requer que $90 \%$ dos erros acidentais não sejam maiores que 1,64 vezes o RMS (isto é, 1,64 desvio-padrão, assumindo a distribuição normal de erros). Portanto:

Erro médio quadrático aceitável $=$ erro aceitável no terreno/valor $\mathrm{z}$ de probabilidade de ocorrência

Erro médio quadrático aceitável $=$ erro aceitável no terreno/1,64

onde:

$$
\begin{aligned}
\text { erro aceitável no terreno }= & \text { erro aceitável no mapa } \times \text { conversão de escala } \mathrm{x} \\
& \text { conversão de unidades } \\
\text { erro aceitável no mapa }= & 1 / 30 \text { polegada para mapas com escala } \leq 1: 20.000 \\
= & 1 / 50 \text { polegada para mapas com escala }>1: 20.000 \\
\text { conversão de unidades }= & 0,0254 \mathrm{~m} / \text { polegada }
\end{aligned}
$$

Assim, determinou-se o erro médio quadrático de diversas combinações de pontos, tanto para os decalques de uso da terra quanto para os mapas. Aquelas combinações que mostrassem valores superiores ao desejado foram sendo descartadas até que a mais adequada restasse.

No presente trabalho, os erros médios quadráticos aceitáveis, calculados pela equação 3 , foram:

- fotografias aéreas de $1940=10,20 \mathrm{~m}$

- fotografias aéreas de 1962 e $1995=12,75 \mathrm{~m}$ 
- fotografias aéreas de $1978=17,85 \mathrm{~m}$

- cartas planialtimétricas $=3,06 \mathrm{~m}$

- $\quad$ carta pedológica $=51 \mathrm{~m}$

\subsubsection{Conversão dos dados}

\subsubsection{Digitalização e edição dos dados}

A digitalização de todo material feita via mesa digitalizadora e pela utilização do software Tosca baseou-se em coordenadas planas, de valores inteiros e tendo por unidade o metro. O valor escolhido para junção de nós (snap nodes) foi sempre igual ou próximo ao valor de RMS informado pelo software Tosca e o valor de tolerância sempre a metade do valor anterior, de acordo com as definições estabelecidas por Jones (1993). A entrada dos dados não espaciais (atributos), via teclado, foi simultânea à digitalização propriamente dita. Para transformação das coordenadas, executou-se por meio do software Tosca uma regressão linear mais ajustada (best-fit linear regression) entre as coordenadas da mesa e do documento. Ainda, por meio desse software orientou-se e ajustou-se a escala do documento na mesa digitalizadora, transformou-se todas as coordenadas digitalizadas em coordenadas do documento e, no final, anotou-se os resultados de RMS informados pelo software.

A digitalização via mesa foi preferida a em tela na crença de que representasse melhor as feições, de que fosse mais simples e mais rápida. Uma das razões para isso reside no fato de que a resolução do cursor da mesa é maior do que a da tela. Além disso, a digitalização das feições de áreas em tela é feita em formato de polígono, ao passo que via mesa é realizada por meio de arcos, o que pode simplificar essa prática, já que as linhas limítrofes são digitalizadas apenas uma vez. 
As curvas de nível e os cursos d'água figurados nas cartas planialtimétricas, os limites de unidades de solo representados na carta de solos e os limites das categorias de uso da terra desenhados nos decalques foram convertidos em arquivos vetoriais.

Posteriormente, no processo de edição, as falhas advindas da digitalização e de outras fontes foram corrigidas utilizando-se o software Tosca.

Feito isso, pela função cycle do software Tosca, converteu-se as feições digitalizadas na forma de arco para formato de polígono com o intuito de possibilitar as transformações dos arquivos vetoriais em matriciais (raster).

Por fim, os arquivos vetoriais dos decalques de uso da terra digitalizados separadamente foram unidos pela função concat do software Tosca.

\subsubsection{Transformação de arquivos vetoriais em matriciais}

Uma vez prontos os mapas de uso da terra e de unidades de solo no formato vetorial, eles foram transformados em matricial por meio do software Idrisi. Para realizar esse processo foi necessário escolher um único tamanho de pixel para todos os planos de informação, com o intuito de haver uma perfeita compatibilidade entre eles, no processo de cruzamento.

A dimensão ideal do pixel foi determinada após um teste realizado com

valores de 1 (um), 3 (três), 5 (cinco) e 10 (dez) metros, onde foram comparados os resultados de área das categorias de uso da terra da microbacia, em todas as datas, tempo de processamento e tamanho de arquivo, para cada um desses valores de pixel. 


\subsubsection{Geração do modelo digital do terreno e do mapa de classes de declividade}

Para geração do modelo digital do terreno da área de estudo foi empregado o arquivo vetorial das curvas de nível, que foi submetido a um processo de interpolação por meio do software Idrisi (função intercon). Essa função utiliza uma interpolação linear entre as curvas de nível.

A partir do modelo foi gerado, então, o mapa de declividades, que foi reclassificado conforme especificações definidas por Sparovek \& Lepsch (1998), resultando, enfim, no mapa de classes de declividade.

3.2.3.4 Geração dos mapas de combinações das unidades de solo com as classes de declividade, de classes de capacidade de uso e de adequação de uso da terra

O mapa de combinações das unidades de solo com as classes de declividade foi obtido pelo cruzamento dos mapas de unidades de solo com o de classes de declividade, empregando-se a função de tabulação cruzada (crosstab), que cruza os dados de dois mapas e elabora um terceiro contendo todas as combinações possíveis.

Já o de classes de capacidade de uso foi obtido por reclassificação do mapa de combinações das unidades de solo com as classes de declividade, conforme especificações definidas por Sparovek \& Lepsch (1998), apresentadas na Tabela 5.

Por sua vez, os mapas de adequação de uso foram obtidos do cruzamento dos mapas de uso da terra em cada data com o mapa de classes de capacidade de uso por 
Tabela 5. Especificações para definição das classes de capacidade de uso.

\begin{tabular}{|c|c|c|}
\hline Unidades de solo & $\begin{array}{c}\text { Classes } \\
\text { de } \\
\text { declividade }\end{array}$ & $\begin{array}{c}\text { Classes de } \\
\text { capacidade } \\
\text { de uso }\end{array}$ \\
\hline associação de podzólicos & $0-2 \%$ & III \\
\hline associação de podzólicos & $2-5 \%$ & III \\
\hline associação de podzólicos & $5-10 \%$ & III \\
\hline associação de podzólicos & $10-15 \%$ & IV \\
\hline associação de podzólicos & $>15 \%$ & VI \\
\hline associação de solo cambissolo com solo aluvial & $0-2 \%$ & II \\
\hline associação de solo cambissolo com solo aluvial & $2-5 \%$ & II \\
\hline associação de solo cambissolo com solo aluvial & $5-10 \%$ & III \\
\hline associação de solo cambissolo com solo aluvial & $10-15 \%$ & III \\
\hline associação de solo cambissolo com solo aluvial & $>15 \%$ & IV $*$ \\
\hline associação de solo litólico com solo podzólico & $0-2 \%$ & IV \\
\hline associação de solo litólico com solo podzólico & $2-5 \%$ & IV \\
\hline associação de solo litólico com solo podzólico & $5-10 \%$ & IV \\
\hline associação de solo litólico com solo podzólico & $10-15 \%$ & IV \\
\hline associação de solo litólico com solo podzólico & $>15 \%$ & VI \\
\hline
\end{tabular}

Fonte: Sparovek \& Lepsch (1998)

* definidos especificamente neste trabalho pelo autor.

meio de aplicação da função tabulação cruzada e reclassificação dos mapas resultantes conforme especificações definidas por Sparovek \& Lepsch (1998), apresentadas na Tabela 6.

Tabela 6. Especificações para definição da adequação de uso da terra.

\begin{tabular}{|c|c|c|c|c|c|}
\hline $\begin{array}{c}\text { Classes de } \\
\text { capacidade } \\
\text { de uso }\end{array}$ & \multicolumn{5}{|c|}{ Categorias de uso da terra } \\
\cline { 2 - 6 } & Cana-de-açúcar & Pastagem & $\begin{array}{c}\text { Vegetação } \\
\text { natural }\end{array}$ & $\begin{array}{c}\text { Agricultura } \\
\text { não canavieira }\end{array}$ & Reflorestamento \\
\hline II & Adequado & Subutilizado & Adequado & Adequado & Subutilizado \\
\hline III & Adequado & Subutilizado & Adequado & Adequado & Subutilizado \\
\hline IV & Risco & Adequado & Adequado & Superutilizado & Adequado \\
\hline VI & Superutilizado & Adequado & Adequado & Superutilizado & Adequado \\
\hline
\end{tabular}

Fonte: Sparovek \& Lepsch (1998) 
O mapa de classes de declividade combinado com o de unidades de solo e o mapa de classes de capacidade de uso foram utilizados na análise da distribuição dos diferentes usos da terra em função do tipo de terreno. Já os mapas de adequação de uso da terra serviram ao propósito de avaliar a adequação nas diferentes datas e dar um indicativo do potencial de degradação das terras da microbacia.

\subsection{Escolha da função do Sistema de Informações Geográficas utilizado para a análise temporal e elaboração do modelo cartográfico}

Visando analisar o uso mais recente (1995) e os anteriores (1978, 1962 e 1940) das terras da microbacia hidrográfica do Ribeirão Pau d'Alhinho, optou-se, em função de testes preliminares, pela função tabulação cruzada que, embora não realize o cruzamento direto dos dados de mais de duas imagens, cada uma representando uma data, e nem diminua a redundância de combinações, efetuou satisfatoriamente a análise temporal. Além de favorecer a interpretação visual do fenômeno estudado, facilitou a observação das mudanças entre as datas. Não obstante, requisitou várias operações e não permitiu a apresentação num único mapa das combinações das quatro datas. Ainda, apresenta a limitação de não permitir mais do que 256 combinações. Cabe mencionar que Schlagel \& Newton (1996) destacaram a dificuldade de visualização dos resultados de sobreposição, devido à complexidade das imagens produridas. Tal limitação foi suficientemente solucionada recorrendo-se a apresentação em mais de um mapa.

Uma vez escolhida a função tabulação cruzada para a análise temporal, um modelo cartográfico foi elaborado para organizar e estruturar os procedimentos visando cumprir o objetivo traçado - investigação do uso mais recente e anterior das terras da microbacia - conforme metodologia citada por Vettorazzi (1997). Esse modelo pode ser visualizado na Figura 3.

Cabe esclarecer que a análise foi iniciada pelo uso da terra da data mais recente (1995), porque essa data foi considerada a mais importante, uma vez que é a mais 


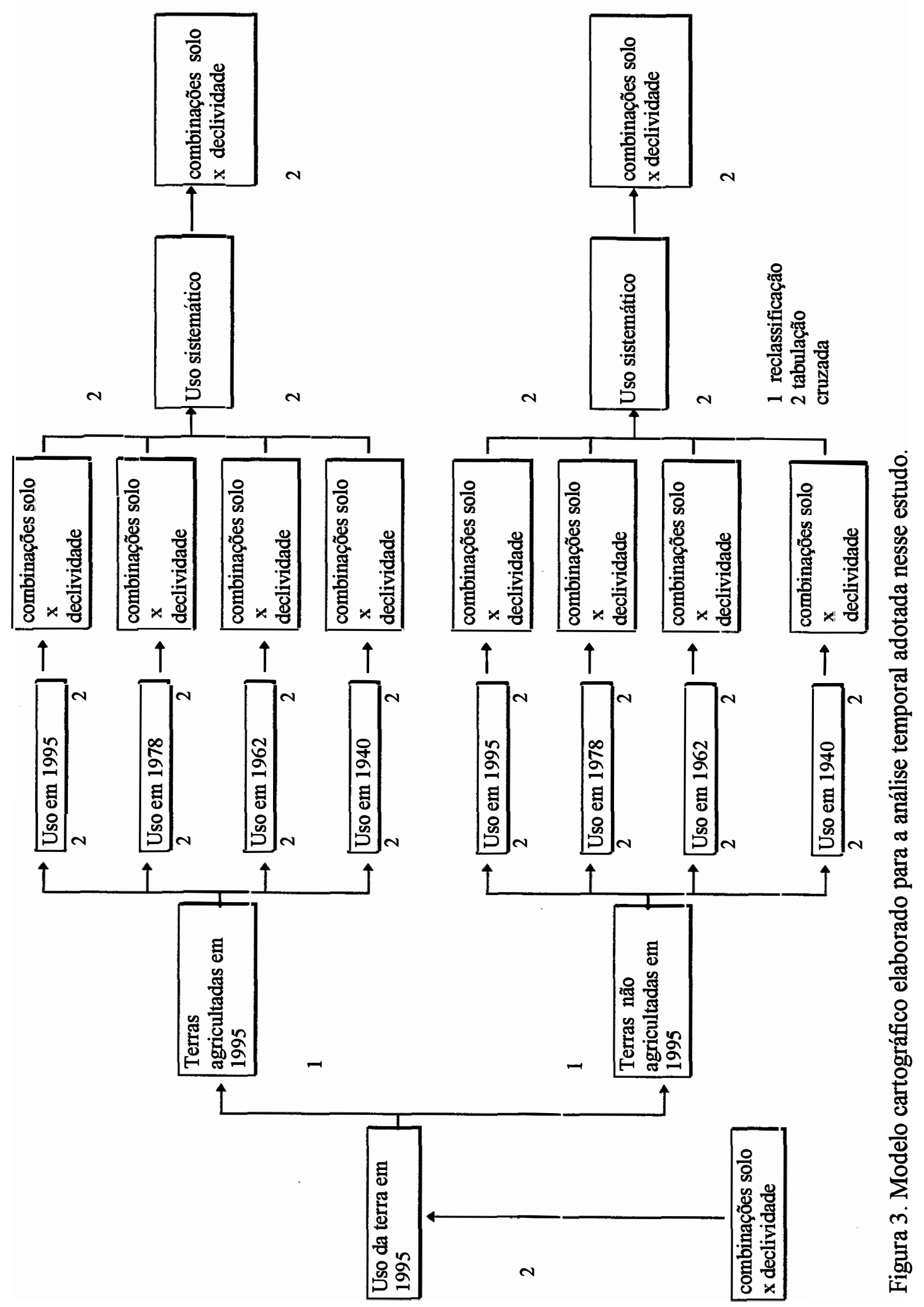


próxima da realidade atual. Além disso, a área de estudo em 1995 foi dividida em áreas agricultadas e não agricultadas, porque o conjunto das categorias com agricultura era $o$ mais extenso da microbacia. Também, esse tipo de ocupação tem possivelmente um efeito impactante maior sobre as terras, conforme Koffler \& Moretti (1991), que consideraram que a capacidade de proteção do solo decresce conforme as seguintes coberturas: mata, pastagem, cultura de ciclo longo e cultura de ciclo curto. Ainda, essa divisão possibilitou investigar de forma mais clara o uso anterior das terras e verificar a existência ou não de um uso recorrente com agricultura, o que reforçaria a hipótese de atividade impactante por um longo período. Ademais, separar essas áreas facilitou a análise, pois diminuiu o número de categorias de uso, tornando a análise mais concentrada e simples. Também permitiu superar a restrição do limite máximo de 256 combinações da função tabulação cruzada. Por fim, um número menor de categorias em muito favoreceu a visualização da dinâmica de ocupação.

\subsection{Análise temporal do uso da terra}

\subsubsection{Situação da microbacia em 1995}

Inicialmente, a função cálculo de área do software Idrisi foi utilizada para dimensionar as áreas das categorias de uso da terra existentes na microbacia em 1995, almejando obter o quadro geral de uso nesse ano. Os dados foram exportados para o software Excel, onde foram organizados na forma de tabelas e utilizados para o cálculo da porcentagem de cada uma das categorias.

Com o mapa de uso da terra em 1995, isolaram-se as áreas da categoria predominante, pela função reclassificação, que realiza uma ordenação conforme especificações do usuário.

Então, foram cruzados o mapa da categoria predominante com o das combinações de unidades de solo e das classes de declividade da microbacia pela função 
tabulação cruzada. Posteriormente, utilizando a função cálculo de área obteve-se o dimensionamento de cada uma dessas combinações e os dados foram exportados para o software Excel. As informações relativas às classes de capacidade de uso foram extraídas diretamente da análise das combinações de unidades de solos com classes de declividade, conforme Sparovek \& Lepsch (1998). Essa etapa teve como objetivo levantar o tipo de terra que a categoria predominante ocupava e sua adequação de uso.

O mesmo foi feito para a segunda categoria predominante, com finalidade idêntica à anterior.

\subsubsection{Usos anteriores das terras da microbacia}

Com o objetivo de verificar quais eram as áreas de cada uma das categorias nas datas estudadas e, conseqüentemente, se ocorria predominância de alguma delas, aplicou-se a função cálculo de área do software Idrisi a cada um dos mapas de uso da terra $(1978,1962$ e 1940). Os dados foram exportados para o software Excel, onde foram organizados em tabelas e usados para o cálculo de porcentagem das categorias.

Em seguida, o mapa de uso da terra em cada data foi cruzado com o mapa de classes de capacidade de uso e reclassificado conforme a adequação de uso da terra, originando os mapas de adequação em todas as datas. Os dados foram exportados para o software Excel, onde, mais uma vez, foram tabulados e usados para o cálculo de porcentagem das classes de adequação.

\subsubsection{Usos anteriores das terras agricultadas em 1995}

As áreas com agricultura em 1995 foram isoladas por intermédio do uso da função reclassificação do software Idrisi. 
O mapa obtido de terras agricultadas em 1995 foi cruzado com os mapas de uso da terra em 1978, 1962 e 1940, utilizando-se a função tabulação cruzada do software Idrisi e o resultado foi reclassificado. Conseqüentemente, foram criados os mapas de uso em 1978, 1962 e 1940 das terras agricultadas em 1995, com o intuito de levantar os usos anteriores dessas áreas.

A seguir, para cada um dos mapas resultantes foram calculadas as áreas pelo mesmo método anteriormente descrito e os dados foram transferidos para o software Excel, onde foram tabulados em termos totais e relativos.

Esses mapas foram, então, cruzados com o das combinações de unidades de solo com as classes de declividade, de onde foram tiradas as classes de capacidade de uso, obtendo-se os dados de adequação de uso das terras agricultadas em 1995 em todas as datas. Mais uma vez o software Excel foi utilizado para tabulação e cálculo das porcentagens. Objetivou-se, assim, estudar a adequação de uso das terras agricultadas em 1995 nas diferentes datas com o intuito de obter um indicativo do potencial de degradação dessas áreas.

Depois, o mapa de uso em 1978 das terras agricultadas em 1995 foi cruzado com o mapa de uso em 1962 das terras agricultadas em 1995 por meio do uso da função tabulação cruzada. O mapa obtido foi reclassificado de tal forma que permanecessem visíveis somente as combinações envolvendo categorias de agricultura. Esse mapa resultante foi cruzado com o mapa de uso em 1940 das terras agricultadas em 1995, aplicando-se as mesmas funçãos nesse segundo mapa e os resultados exportados para o software Excel e tabulados. Dessa forma, levantou-se as terras que foram agricultadas sistematicamente em todas as datas.

Por sua vez, o mapa final de ocupação sistemática das terras agricultadas em 1995 foi cruzado com o mapa das combinações de unidades de solos e das classes de declividade, que trazem, como explicado anteriormente, as classes de capacidade de uso. 
O mapa assim obtido foi reclassificado para isolar as terras inadequadamente utilizadas, buscando verificar quais terras tiveram uso sistemático inadequado, isto é, com maior probabilidade de degradação.

\subsubsection{Usos anteriores das terras não agricultadas em 1995}

Recorreu-se ao mesmo procedimento utilizado para avaliar as terras agricultadas em 1995 para as demais terras da microbacia, ou seja, as terras não agricultadas.

\subsubsection{Composição do quadro de uso das terras da microbacia em 1995}

\subsubsection{Composição das terras agricultadas em 1995}

A composição do quadro de uso das terras agricultadas em 1995 é o produto das transformações ocorridas nas datas anteriores, ou seja, da dinâmica dos processos de aquisição e perdas de áreas pelas categorias de uso em questão.

Para essa análise foram utilizados os dados de uso mais recente e anteriores das terras agricultadas em 1995, obtidos nos itens 3.4.1 e 3.4.2.1.

O mapa das terras agricultadas em 1995 e os mapas de uso em 1978, 1962 e 1940 das terras agricultadas em 1995 foram cruzados com o mapa das combinações de unidades de solo e das classes de declividade, contendo as classes de capacidade de uso, por aplicação da função tabulação cruzada do software Idrisi. A seguir, a de cálculo de área foi usada para obtenção das áreas. Os dados resultantes foram exportados para o software Excel, por meio do qual foram calculadas as porcentagens. 
Desse modo, foi possível averiguar sobre que tipos de terra o quadro das terras agricultadas em 1995 se compôs, isto é, sobre quais ocorreram expansão, retração e manutenção das diversas categorias de uso.

\subsubsection{Composição das terras não agricultadas em 1995}

$\mathrm{O}$ mesmo procedimento foi adotado para as demais terras da microbacia $\mathrm{e}$ com o mesmo objetivo de verificar sobre que tipos de terra ocorreram expansão, retração e manutenção das diversas categorias de uso nas terras não agricultadas em 1995.

\subsubsection{Dinâmica temporal de ocupação da categoria vegetação nativa}

A vegetação nativa foi analisada devido a sua importância como indicador da conservação das terras da microbacia. Com o intuito de estudar sua dinâmica, foram usados os dados de uso da terra da microbacia em 1995 e dos usos anteriores das terras agricultadas e não agricultadas em 1995.

Para a obtenção da dinâmica, o mapa de uso da terra em 1995 foi cruzado com o de 1978 utilizando-se a função tabulação cruzada do software Idrisi. Os dados resultantes foram reclassificados em vegetação nativa e outros. $\mathrm{O}$ mapa obtido foi cruzado com o mapa de uso da terra da microbacia em 1962 e assim por diante até 1940, originando o mapa representativo da dinâmica temporal da vegetação nativa.

\subsubsection{Ocupação das áreas de preservação permanente}

A ocupação das áreas de preservação permanente foi abordada para levantar o uso das terras nessas áreas tão importantes sob o ponto de vista ambiental.

As áreas de preservação permanente, segundo o Código Florestal, foram demarcadas pela aplicação da função buffer do software Idrisi aos arquivos matriciais 
dos cursos d'água (transformação vetor-matriz de arquivos com estrutura de linha), represas (transformação vetor-matriz de arquivos com estrutura de polígono) e nascentes (transformação vetor-matriz de arquivos com estrutura de ponto). Nesse caso em questão, determina-se que é obrigatória a preservação de uma faixa de $30 \mathrm{~m}$ margeando os cursos d'água e $50 \mathrm{~m}$ as nascentes e corpos d'água. Em seguida, esses arquivos foram unificados por meio de aplicação da função tabulação cruzada e o mapa resultante foi reclassificado.

O mapa com essas áreas demarcadas foi cruzado com o mapa de uso da terra da microbacia em cada uma das datas estudadas para se inventariar o uso das terras nas áreas de preservação permanente. Para tanto, empregou-se a função tabulação cruzada do software Idrisi e as combinações obtidas foram reclassificadas. Mais uma vez o resultados dessa reclassificação foram exportados para o software Excel e tabulados.

Por fim, com o objetivo de levantar o uso das cabeceiras da microbacia, fundamentais para a estabilidade da rede de drenagem, $o$ arquivo matricial de nascentes foi cruzado com o mapa de uso da terra da microbacia em cada uma das datas utilizandose a função tabulação cruzada. Os mapas resultantes foram reclassificados, exportados para o software Excel e tabulados. 


\section{RESULTADOS E DISCUSSÃO}

\subsection{Levantamento e preparação dos dados}

\subsubsection{Fotointerpretação e definição da legenda}

Como resultado da fotointerpretação foi obtida uma série de decalques, que posteriormente, foram digitalizados.

Em geral, a identificação de alvos nas datas de 1995, 1978 e 1962 não apresentou grandes dificuldades. Isso porque o tipo de ocupação manteve-se constante numa área considerável da microbacia. Ainda, pode-se afirmar que o uso das fotografias dessas três "datas foi facilitado pela maior qualidade das imagens fotográficas e conhecimento das práticas agrícolas pelo fotointérprete.

Os elementos de reconhecimento mais usados, igualmente a Fiorio (1998), Borges et al. (1993), Koffler (1979) e Audi (1965), foram: textura, porte, tonalidade, telhado e aspectos associados, conforme pode ser confirmado na Tabela 7.

Apesar dos elementos de reconhecimento ajudarem a identificar os alvos, uma dificuldade encontrada foi discernir algumas áreas de cana-de açúcar de pasto, fato que já havia ocorrido com Audi (1965). Esse problema ficou evidenciado quando se comparou os dados de uso da terra da microbacia hidrográfica do Ribeirão Pau d'Alhinho 


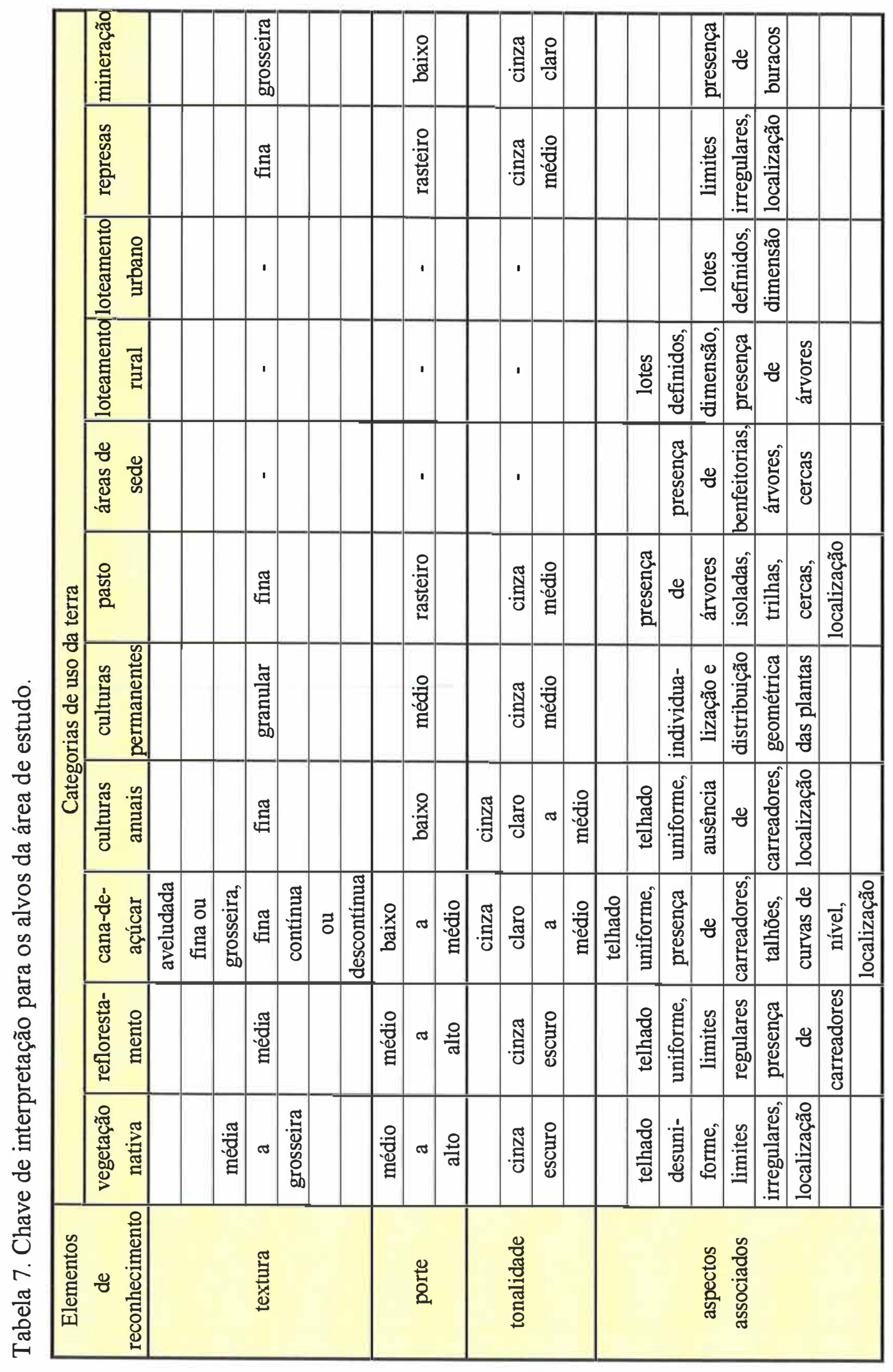


obtidos nesse trabalho (Tabela 15) com os apontados por Sparovek \& Lepsch (1998) na Tabela 1. A discrepância entre os valores de área das categorias cana e pasto ocorreu em 1962, devido à interpretação das fotografias aéreas dessa data e, no caso mais recente, ao fato de que aqueles autores avaliaram o ano de 1991, ao invés de 1995, e recorreram a imagem de satélite e não a fotografias aéreas convencionais.

Outra dificuldade, com menor expressão, foi classificar algumas áreas de terra arada, que tanto poderiam estar sendo preparadas para o plantio de cana-de açúcar como para alguma cultura anual. Nesses casos, o uso das terras no entorno auxiliou a definição de sua categoria. É oportuno afirmar que, em geral, a identificação da categoria cana-de-açúcar foi feita pelo processo de seleção e a da culturas anuais por eliminação.

Já, a escala das fotografias aéreas de 1995 favoreceu sua interpretação, como havia dito Fiorio (1998). Além disso, esse benefício foi reforçado pela maior qualidade das fotografias e a possibilidade de checagem em campo.

Por sua vez, a identificação dos alvos em 1978 foi facilitada pela semelhança de suas características às de 1995, principalmente pela permanência da cultura de cana-de-açúcar nas mesmas áreas. Em contrapartida, ela foi prejudicada pelo menor nível de detalhamento proporcionado pela escala, fato contrário ao encontrado por Fiorio (1998), que afirmou que o nível de detalhamento é o mesmo entre as fotografias aéreas de 1978 e 1995.

No que concerne à identificação dos alvos representados nas fotografias aéreas de 1962, apesar de sua escala permitir um maior nível de detalhamento do que as de 1978, a qualidade das imagens fotográficas ser boa e as práticas agrícolas coincidirem, o maior distanciamento temporal dificultou e começou a interferir na confiabilidade do fotointérprete nos resultados. Dúvidas surgiram com maior intensidade, principalmente, em terras preparadas, seja para reflorestamento, cultura anual ou cana-de-açúcar. 
A interpretação das fotografias aéreas de 1940 foi bem mais complicada do que as últimas três datas, estando num outro nível de dificuldade. A antigüidade dessas imagens gerou problemas na identificação dos alvos, repetindo o padrão indicado por Baker (1979), o que mostra que nem sempre o maior nível de detalhamento proporcionado pela escala facilita o trabalho. Discenir terra preparada para cultura anual de pasto foi problemático, tanto devido à qualidade das imagens fotográficas, como pela ocupação caótica dos campos. Ainda, com relação às terras preparadas, foi complicado classificá-las como cultura permanente ou cultura anual. Da mesma forma, foi trabalhoso, em certas áreas, diferenciar reflorestamento de vegetação natural, dificuldade que se repetiu em algumas áreas das fotografias aéreas de 1978 e 1962.

Apesar de todos esses obstáculos, o uso dessas fotografias foi justificado pela predominância, nesse caso, de áreas de pasto, mais facilmente identificáveis, devido aos fortes indicativos tais como áreas extensas de campo, trilhas de gado e áreas diminutas de capoeira, fenômeno que provocou o aumento na confiabilidade dos dados. Além disso, a utilização de dados antigos propiciou um estudo mais amplo. Por exemplo, apenas os dados de 1940 serviram como parâmetro para a análise que antecedeu a grande revolução agrícola que houve na região, com a expansão agressiva da cana-de-açúcar a partir de 1950 (Angulo Filho, 1981) e a influência determinante de uma política agrícola de incentivo para determinada cultura. Ainda, dispor de dados de área coberta por vegetação nativa, bem como de sua distribuição espacial, em 1940, foi precioso para tornar a avaliação dessa categoria, importante sob o ponto de vista de preservação ambiental, mais completa.

Um outro aspecto estava realacionado à classificação das áreas marginais, isto é, aquelas com maiores limitações de uso, como vizinhas aos cursos d'água, muito declivosas, pedregosas, muito rasas etc. Uma vez que elas estavam cobertas por vegetação rasteira, em geral, nas quatro datas e sem indícios de regeneração de vegetação nativa, deduziu-se que estavam sendo usadas como pastagem. 
Quanto à descrição das categorias de uso da terra, a categoria áreas de sede foi definida como aquelas áreas que continham a sede da propriedade rural, suas benfeitorias e cercanias utilizadas.

Já a categoria mineração correspondeu às áreas nas quais foi verificada a remoção do solo para exploração de argila ou calcário etc.

Os loteamentos foram estabelecidos em função de seu aspecto bem característico como presença de muros, construções etc. A diferença entre o rural e o urbano foi definida conforme a presença de árvores e as dimensões dos lotes.

A vegetação nativa englobou as áreas de capoeira e mata, ou seja, áreas com pouca interferência antrópica.

Por fim, a categoria culturas semi-permanentes foi renomeada como canade-açúcar, uma vez que essa cultura foi a única encontrada.

A legenda definitiva ficou como apresentada a seguir:

- vegetação nativa

- reflorestamento

- cana-de-açúcar

- culturas anuais

- culturas permanentes

- pasto

- áreas de sede

- loteamento rural

- loteamento urbano

- represas

- mineração 


\subsubsection{Seleção dos pontos de controle}

O resultado dos números de pontos de controle demarcados, descartados e selecionados, tanto para as fotografias aéreas, quanto para os mapas, são apresentados na Tabela 8 .

Tabela 8. Números de pontos de controle demarcados, descartados e selecionados para as fotografias aéreas e as cartas.

\begin{tabular}{|c|c|c|c|c|c|c|c|c|}
\hline \multirow{2}{*}{$\begin{array}{c}\text { Pontos de } \\
\text { controle }\end{array}$} & \multicolumn{7}{|c|}{ fotografias aéreas de 1940} & \\
\hline & $n^{0} 41$ & $n^{\circ} 42$ & $\mathrm{n}^{\circ} 43$ & $n^{\circ} 44$ & $n^{\circ} 45$ & $\mathrm{n}^{\circ} 64$ & $n^{0} 65$ & \\
\hline $\mathrm{n}^{\mathrm{o}}$ de $\mathrm{p}^{\text {tos }}$ demarcados & 7 & 10 & 8 & 6 & 7 & 10 & 6 & \\
\hline $\mathrm{n}^{\mathrm{o}}$ de $\mathrm{p}^{\text {tos }}$ descartados & 3 & 3 & 4 & 1 & 2 & 3 & 2 & \\
\hline$n^{\circ}$ de $p^{\text {tos }}$ selecionados & 4 & 7 & 4 & 5 & 5 & 7 & 4 & \\
\hline \multirow{2}{*}{$\begin{array}{l}\text { Pontos de } \\
\text { controle }\end{array}$} & \multicolumn{3}{|c|}{ fotografias áreas 1962} & \multicolumn{2}{|c|}{ fotografias 1978} & \multicolumn{3}{|c|}{ fotografias aéreas 1995} \\
\hline & $\mathrm{n}^{\mathrm{o}} 9594$ & $\mathrm{n}^{\circ} 9595$ & $\mathrm{n}^{\circ} 9596$ & $\mathrm{n}^{\mathrm{o}} 2903$ & $\mathrm{n}^{\mathrm{o}} 2064$ & $\mathrm{n}^{\circ} 13$ & $\mathrm{n}^{\mathrm{o}} 14$ & $\mathrm{n}^{\mathrm{o}} 15$ \\
\hline $\mathrm{n}^{\mathrm{o}}$ de $\mathrm{p}^{\text {tos }}$ demarcados & 9 & 12 & 8 & 18 & 5 & 11 & 9 & 7 \\
\hline $\mathrm{n}^{\mathrm{o}}$ de $\mathrm{p}^{\text {tos }}$ descartados & 4 & 6 & 3 & 6 & - & 6 & 4 & 3 \\
\hline$n^{\circ}$ de p $p^{\underline{t o s}}$ selecionados & 5 & 6 & 5 & 12 & 5 & 5 & 5 & 4 \\
\hline \multirow{2}{*}{$\begin{array}{l}\text { Pontos de } \\
\text { controle }\end{array}$} & \multicolumn{3}{|c|}{ cartas planialtimétricas } & \multicolumn{2}{|c|}{ carta pedológica } & & & \\
\hline & $071 / 088$ & $072 / 088$ & $073 / 088$ & \multicolumn{2}{|c|}{ folha Piracicaba } & & & \\
\hline $\mathrm{n}^{\circ}$ de $\mathrm{p}^{\text {tos }}$ demarcados & 4 & 4 & 4 & 4 & - & & & \\
\hline $\mathrm{n}^{\mathrm{o}}$ de $\mathrm{p}^{\text {tos }}$ descartados & 0 & 0 & 0 & 0 & - & & & \\
\hline no de p pos $^{\text {tos }}$ selecionados & 4 & 4 & 4 & 4 & - & & & \\
\hline
\end{tabular}

Chama atenção o número razoável de pontos demarcados e escolhidos nos decalques de uso da terra correspondentes às fotografias aéreas de 1940, tornando possivel, então, a conversão dos dados extraídos dessas fotografias. No entanto, o número de pontos de grande parte das fotografias de 1940 e dos outros documentos para transformação de coordenadas pelo software Tosca foi limitado.

Apesar da escolha dos pontos de controle ter demandado muito trabalho e atenção, especialmente por causa da incerteza de que os pontos localizados nas cartas planialtimétricas correspondiam corretamente àqueles determinados nas fotografias 
aéreas, o esforço empregado foi compensado por facilitar os trabalhos posteriores, além de fornecer dados mais confiáveis. Com relação à demarcação de pontos de controle nas fotografias aéreas de 1940, um aspecto favorável foi o reconhecimento de objetos em 1940, que permaneceram até a data de confecção das cartas planialtimétricas.

Embora tenha havido um esforço para inclusão de pontos de controle comuns a decalques adjacentes (Wolf, 1983), conforme mencionado no item 3.2.2.2, a geometria de pontos avaliada muitas vezes resultava num nível de exatidão inaceitável. Ou seja, não foi possível, em geral, incluir esses pontos na geometria definitiva. Além disso, esperando que corrigisse melhor as distorções e, ao mesmo tempo, garantisse uma maior confiabilidade nos dados e um grau de exatidão aceitável, foi privilegiada uma distribuição de pontos similar à recomendada por Farret (1996 e 1997), isto é, um ponto próximo a cada canto do decalque.

\subsection{Conversão dos dados}

\subsubsection{Digitalização e edição dos dados}

Os resultados dos erros médios quadráticos (RMS) para os produtos digitalizados estão apresentados na Tabela 9.

Tabela 9. Erros médios quadráticos para os produtos digitalizados.

\begin{tabular}{|c|c|c|c|c|c|c|c|c|}
\hline \multirow{2}{*}{$\begin{array}{c}\text { Pontos de } \\
\text { controle escolhidos }\end{array}$} & \multicolumn{7}{|c|}{ fotografias aéreas de 1940} & \\
\hline & $n^{\circ} 41$ & $n^{\circ} 42$ & $\mathrm{n}^{\circ} 43$ & $\mathrm{n}^{\circ} 44$ & $n^{\circ} 45$ & $\mathrm{n}^{\circ} 64$ & $n^{\circ} 65$ & \\
\hline RMS (m) & 6.56 & 10,01 & 8.66 & 8,25 & 9,4 & 8,56 & 7,79 & \\
\hline Pontos de & \multicolumn{8}{|c|}{ fotografias aéreas 1962 fotografias 1978 fotografias aéreas 1995} \\
\hline controle escolhidos & $n^{\circ} 959$ & & $n^{\circ} 9596$ & no 2903 & $\mathrm{n}^{\circ} 2964$ & $\mathrm{n}^{\circ} 13$ & $\mathrm{n}^{\circ} 14$ & $\mathrm{n}^{\mathrm{o}} 15$ \\
\hline RMS (m) & 6,89 & 8,88 & 8,54 & 17,56 & 10,85 & 5,62 & 9,88 & 8,79 \\
\hline Pontos de & \multicolumn{3}{|c|}{ cartas planialtimétricas } & \multicolumn{2}{|c|}{ carta pedológica } & & & \\
\hline controle escolhidos & $071 / 08 \varepsilon$ & $072 / 088$ & $073 / 088$ & folha $\mathrm{Pi}$ & racicaba & & & \\
\hline RMS (m) & 1,25 & 1,88 & 1.51 & 21,56 & 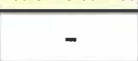 & & & \\
\hline
\end{tabular}


Observa-se que os erros médios quadráticos de todos os documentos estão dentro da faixa de erro aceitável, de acordo com os procedimentos apresentados em 3.2.2.2.

É oportuno afirmar que as causas mais prováveis destes erros, em sua maioria já apontadas por Jones (1993), foram:

- coordenação visual-motora;

- erros de confecção, distorções causadas, principalmente, por variações de umidade e temperatura e problemas de deterioração das próprias cartas planialtimétricas, de onde foram extraídas as coordenadas dos pontos;

- distorções e problemas de deterioração das fotografias aéreas;

- pequenas alterações dos elementos geográficos usados como pontos de controle no período de tempo estudado (por exemplo, pequenas mudanças na confluência de estradas, nos cursos dos rios, desbarrancamentos etc.);

- erros do algoritmo de transformação de coordenadas do software Tosca.

Ficou claro que, apesar da grande vantagem de se tomar as coordenadas por meio das cartas planialtimétricas, esse procedimento pode ter agregado erros que possivelmente seriam minimizados, caso a medição fosse feita diretamente no campo (por meio de um equipamento GPS adequado, por exemplo). Cabe recordar que Vitek et al. (1984) defenderam a idéia de que a integração de dados de exatidão duvidosa produz resultados questionáveis.

Um tema a se destacar é a importância que foi dada à apresentação dos RMSs como um indicativo de exatidão do documento a ser digitalizado. Afinal, o processo de digitalização só se iniciava quando os resultados de RMSs, apresentados 
pelo software Tosca, eram aceitáveis, indicando confiabilidade e qualidade. No entanto, vale lembrar que, quando se trabalha com fotografias aéreas não retificadas, os erros médios quadráticos apresentados para a digitalização dos decalques estimam apenas grosseiramente os desvios oriundos das distorções aleatórias das fotografias aéreas. $\mathrm{E}$, também, que a confiabilidade nos dados, conforme Jones (1993), depende do número de pontos de controle usados para o georreferenciamento do documento.

No que concerne à qualidade de conversão dos dados extraídos das fotografias aéreas, apesar de não ter sido feito um controle após essa etapa, é possível afirmar que ela apresentou resultados satisfatórios, pois atendeu às especificações do trabalho. Embora Bolstad (1992) não recomende o emprego de fotografias aéreas não retificadas, em trabalhos de análise temporal e análises genéricas isso seria possível. Afinal, na análise temporal tem-se a referência de várias datas, o que confirmaria os dados de posição geográfica dos limites das categorias e nas genéricas pequenos deslocamentos geométricos não prejudicariam a qualidade. Os resultados obtidos nesse estudo provaram que o seu uso direto, conforme Wolf (1983) e Farret (1996) é viável. Além disso, o método mostrou que sua aplicação é de pouca complexidade e relativamente barato, como já apontado por Farret (1996). Então, é possível inferir-se que a relação custo/benefício da exatidão dos dados obtidos mostrou-se adequada, estando de acordo com a afirmação de Aronoff (1995).

Apesar da pertinência do método adotado, não é possível deixar de registrar que, na etapa de edição dos arquivos vetoriais, foi demandado um trabalho exaustivo para corrigir os problemas encontrados.

No processo de edição, ficou constatado que as principais falhas apresentadas foram: entrada equivocada de dados não espaciais; linhas desunidas; linhas digitalizadas repetidamente e disparidades nos limites dos decalques. Essas falhas também foram identificadas por Burrough (1986). 
$\mathrm{O}$ ajuste mais demorado e cansativo foi corrigir as pequenas lacunas e sobreposições de áreas que surgiram após a união entre os arquivos vetoriais digitalizados separadamente. As causas mais prováveis para esse problema, em grande parte já citadas por Burrough (1986) e Star \& Estes (1990), foram as apontadas anteriormente, acrescidas dos erros de digitalização (Maffini, 1989; Thapa \& Bossler, 1992; Oliveira et al., 1995). Soma-se, ainda, o fato de que, em geral, os pontos de controle localizados nas adjacências de um decalque com o outro não eram os mesmos e, assim, a transformação das coordenadas pelo software Tosca não se baseou em pontos comuns.

Cabe recordar que as distorções das fotografias aéreas são mais intensas nas bordas, região onde justamente ocorre a união dos decalques, o que favoreceu a formação dessas pequenas discrepâncias nos limites. Ainda, conforme Farret (1996), a solução matemática empregada pelo método de transformação de coordenadas produz melhores resultados nas regiões próximas aos pontos de controle.

Com relação aos erros de digitalização é pertinente afirmar que ocorreram, principalmente, devido à dificuldade de visualização das feições, já abordada por Maffini (1989). Esse problema poderia ser amenizado ampliando-se os decalques por meio de projetores apropriados ou as imagens dos decalques capturadas por scanner seriam ampliadas pelo SIG utilizado. No caso das cartas planialtimétricas, a dificuldade de visualização decorreu da proximidade entre algumas curvas de nível. Essa restrição poderia ser evitada com uma digitalização semi-automática (Quintanilha, 1996). Ainda, a digitalização foi completada após duas ou três sessões de trabalho. Assim, os mapas foram georreferenciados também duas ou três vezes, o que provocou pequenas diferenças de posicionamento de algumas linhas. Esse problema, portanto, faz recomendar, quando possível, a digitalização numa única etapa, passando por apenas uma calibração da mesa (Oliveira et al., 1995). 
Quanto às conseqüências das correções dos erros visíveis após a união dos arquivos vetoriais digitalizados separadamente, os dados de uso da terra das áreas limítrofes não são completamente confiáveis, uma vez que, no momento da decisão da correção, não era possível determinar a direção dos desvios dos arquivos. Entretanto, em geral, somente categorias de uso da terra inexpressivas em termos de área foram prejudicadas, como áreas de sede e outras.

Em razão do trabalho exaustivo para corrigir os problemas de lacunas e sobreposição de áreas surgidos após a união dos arquivos vetoriais, recomenda-se experimentar transferir os dados de uso da terra para um mapa-base, geralmente uma carta planialtimétrica, para depois, sim, digitalizá-lo. A transferência se daria, principalmente, por triangulação radial gráfica (Wolf, 1983; Barros, 1987) ou pela utilização de instrumentos de projeção ou reflexão (Baker et al., 1979; Wolf, 1983; Barros \& Cardoso, 1992; Campos et al., 1993; Warner et al., 1996).

\subsubsection{Transformação de arquivos vetoriais em matriciais}

Os resultados de tamanho dos arquivos gerados, tempo de processamento e área das diversas categorias de uso da terra, em função do tamanho dos pixels, são apresentados nas Tabelas 10 e 11.

Tabela 10. Tamanho relativo dos arquivos gerados e tempo relativo de processamento, em função do tamanho dos pixels.

\begin{tabular}{|c|c|c|c|c|}
\hline & $10 \mathrm{~m} \times 10 \mathrm{~m}$ & $5 \mathrm{~m} \times 5 \mathrm{~m}$ & $3 \mathrm{~m} \times 3 \mathrm{~m}$ & $1 \mathrm{~m} \times 1 \mathrm{~m}$ \\
\hline \multirow{2}{*}{$\begin{array}{c}\text { tamanho relativo de arquivo } \\
\text { tempo relativo de processamento }\end{array}$} & $1 \mathrm{x}$ & $4,03 \mathrm{x}$ & $11,18 \times$ & $100,66 \mathrm{x}$ \\
\cline { 2 - 5 } & $1 \mathrm{x}$ & 3,18 & $6,75 \times$ & $48,63 \mathrm{x}$ \\
\hline
\end{tabular}

Observa-se que, enquanto as áreas das diversas categorias permaneceram semelhantes, o tamanho dos arquivos e o tempo de processamento modificaram bastante. 
Tabela 11. Áreas das diversas categorias de uso da terra, obtidas dos respectivos mapas com diferentes tamanhos de pixel ( $10 \mathrm{~m} \times 10 \mathrm{~m}, 5 \mathrm{~m} \times 5 \mathrm{~m}, 3 \mathrm{~m} \times 3 \mathrm{~m}, 1 \mathrm{~m} \times 1 \mathrm{~m})$.

\begin{tabular}{|c|c|c|c|c|}
\hline \multirow{2}{*}{$\begin{array}{l}\text { Categorias de } \\
\text { uso da terra }\end{array}$} & \multicolumn{4}{|c|}{1995} \\
\hline & $10 \mathrm{~m} \times 10 \mathrm{~m}$ ( ha $)$ & $5 \mathrm{~m} \times 5 \mathrm{~m}(\mathrm{ha})$ & $3 \mathrm{~m} \times 3 \mathrm{~m}(\mathrm{ha})$ & $1 \mathrm{~m} \times 1 \mathrm{~m}(\mathrm{ha})$ \\
\hline v.nat. & 121,35 & 121,28 & 121,42 & 121,34 \\
\hline reflor. & 11,49 & 11,5 & 11,54 & 11,54 \\
\hline cana & 827,06 & 827,24 & 827,33 & 827,36 \\
\hline c.an. & 34,68 & 34,74 & 34,75 & 34,73 \\
\hline pasto & 427,26 & 427,47 & 427,36 & 427,38 \\
\hline á.sede & 40,99 & 40,75 & 40,69 & 40,70 \\
\hline 1.rural & 23,91 & 23,89 & 23,83 & 23,85 \\
\hline l.urb. & 4,78 & 4,83 & 4,83 & 4,82 \\
\hline repres. & 7,86 & 7,88 & 7,87 & 7,87 \\
\hline miner. & 6,21 & 6,20 & 6,21 & 6,21 \\
\hline Total & 1505,59 & 1505,85 & 1505,87 & 1505,83 \\
\hline \multirow{2}{*}{$\begin{array}{l}\text { Categorias de } \\
\text { uso da terra }\end{array}$} & \multicolumn{4}{|c|}{1978} \\
\hline & $10 \mathrm{~m} \times 10 \mathrm{~m}$ ( ha $)$ & $5 \mathrm{~m} \times 5 \mathrm{~m}(\mathrm{ha})$ & $3 \mathrm{~m} \times 3 \mathrm{~m}$ ( ha ) & $1 \mathrm{~m} \times 1 \mathrm{~m}(\mathrm{ha})$ \\
\hline v.nat. & 165,04 & 165,13 & 165,26 & 165,23 \\
\hline reflor. & 30,3 & 30,46 & 30,43 & 30,45 \\
\hline cana. & 783,25 & 782,92 & 783,14 & 783,08 \\
\hline c.an. & 12,41 & 12,41 & 12,42 & 12,42 \\
\hline c.prm. & 73,68 & 73,79 & 73,79 & 73,78 \\
\hline pasto & 401,98 & 402,02 & 401,89 & 401,91 \\
\hline á.sede & 37,34 & 37,46 & 37,29 & 37,33 \\
\hline repres. & 1,64 & 1,63 & 1,63 & 1,63 \\
\hline Total & 1505,64 & 1505,85 & 1505,88 & 1505,86 \\
\hline \multirow{2}{*}{$\begin{array}{c}\text { Categorias de } \\
\text { uso da terra }\end{array}$} & \multicolumn{4}{|c|}{1962} \\
\hline & $10 \mathrm{~m} \times 10 \mathrm{~m}$ ( ha $)$ & $5 \mathrm{~m} \times 5 \mathrm{~m}$ ( ha ) & $3 \mathrm{~m} \times 3 \mathrm{~m}$ ( ha ) & $1 \mathrm{~m} \times 1 \mathrm{~m}($ ha $)$ \\
\hline v.nat. & 188,87 & 188,92 & 189,08 & 188,98 \\
\hline reflor. & 161,01 & 161,26 & 161,25 & 161,25 \\
\hline cana. & 466,88 & 467,29 & 467,29 & 467,30 \\
\hline c.an. & 23,84 & 23,83 & 23,78 & 23,80 \\
\hline c.prm. & 80,31 & 80,43 & 80,37 & 80,34 \\
\hline pasto & 568,4 & 567,56 & 567,61 & 567,68 \\
\hline á.sede & 13,98 & 14,10 & 14,05 & 14,08 \\
\hline miner. & 2,34 & 2,43 & 2,39 & 2,38 \\
\hline Total & 1505,63 & 1505,85 & 1505,86 & 1505,84 \\
\hline \multirow{2}{*}{$\begin{array}{l}\text { Categorias de } \\
\text { uso da terra }\end{array}$} & \multicolumn{4}{|c|}{1940} \\
\hline & $10 \mathrm{~m} \times 10 \mathrm{~m}$ ( ha $)$ & $5 \mathrm{~m} \times 5 \mathrm{~m}$ ( ha ) & $3 \mathrm{~m} \times 3 \mathrm{~m}$ ( ha ) & $1 \mathrm{~m} \times 1 \mathrm{~m}(\mathrm{ha})$ \\
\hline v.nat. & 186,83 & 186,98 & 187,10 & 187,05 \\
\hline reflor. & 6,01 & 6,04 & 6,03 & 6,04 \\
\hline cana. & 14,04 & 14,24 & 14,17 & 14,18 \\
\hline c.an. & 426,56 & 426,42 & 426,32 & 426,35 \\
\hline c.prm. & 136,86 & 136,59 & 136,57 & 136,59 \\
\hline pasto & 718,27 & 718,42 & 718,47 & 718,43 \\
\hline á.sede & 17 & 17,13 & 17,12 & 17,13 \\
\hline Total & 1505,57 & 1505,85 & 1505,81 & 1505,79 \\
\hline
\end{tabular}


Ponderando-se os resultados, optou-se pelo pixel de 5 metros, uma vez que, além de possuir tamanho relativo de arquivo e tempo relativo de processamento adequados, representou satisfatoriamente todos os polígonos demarcados. Quanto ao último fator, Quintanilha (1996) indicou a complexidade do desenho como um dos elementos ao qual os parâmetros básicos a serem controlados na conversão vetor-matriz diz respeito.

\subsubsection{Dados obtidos de unidades de solo, modelo digital do terreno e das classes de declividade}

Os dados de unidades de solo, do modelo digital do terreno, de classes de declividade encontram-se nas Tabelas 12 e 13 e Figuras 2, 4 e 5.

Tabela 12. Áreas das unidades de solo da microbacia.

\begin{tabular}{|c|c|c|}
\hline Unidades de solo & Hectares & $\%$ \\
\hline asociação de solos podzólicos & 712,02 & 47,28 \\
\hline associação de solo cambissolo com solo aluvial & 56,94 & 3,78 \\
\hline associação de solo litólico com solo podzólico & 736,90 & 48,94 \\
\hline Total & 1505,85 & 100,00 \\
\hline
\end{tabular}

Tabela 13. Áreas das classes de declividade da microbacia.

\begin{tabular}{|c|c|c|}
\hline Classes de declividade & Hectares & $\%$ \\
\hline $0-2 \%$ & 198,51 & 13,18 \\
\hline $2-5 \%$ & 136,83 & 9,09 \\
\hline $5-10 \%$ & 422,01 & 28,02 \\
\hline $10-15 \%$ & 429,27 & 28,51 \\
\hline$>15 \%$ & 319,24 & 21,20 \\
\hline Total & 1505,85 & 100,00 \\
\hline
\end{tabular}

É oportuno comentar que as divergências de área entre os dados obtidos nesse trabalho e os de Sparovek \& Lepsch (1998), apresentados no item 3.1.1, decorreram de opções metodológicas diferentes. Os autores citados utilizaram a carta de 




Figura 4. Modelo digital do terreno da microbacia hidrográfica do Ribeirão Pau d'Altrinho. 


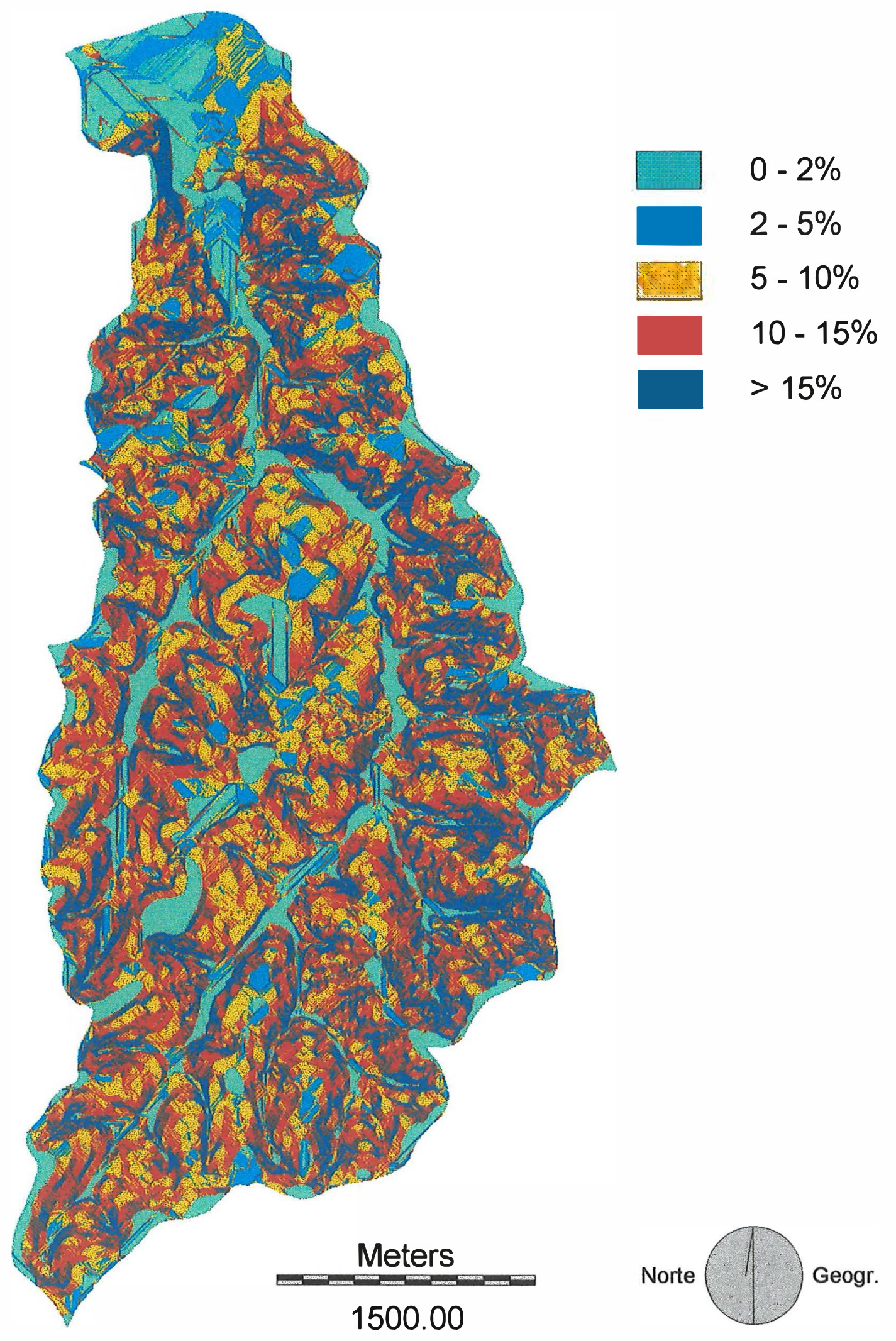

Figura 5. Classes de declividade da microbacia hidrográfica do Ribeirão Pau d'Alhinho. 
solos de Piracicaba (Oliveira \& Prado, 1989), cartas planialtimétricas do Instituto Brasileiro de Geografia e Estatística (IBGE) com escala de 1: 50.000, o método desenvolvido por de Biasi para delimitação das classes de declividade, software AutoCAD para digitalização e edição dos dados, tamanho de pixel que representa 6,25 ha no terreno e o software Gmap para o gerenciamento dos dados.

\subsubsection{Dados obtidos de combinações das unidades de solo com as classes de declividade e de classes de capacidade de uso}

Os dados de combinações das unidades de solo com as classes de declividade e de classes de capacidade de uso encontram-se nas Tabelas 14 e 15 e Figuras 6 e 7.

Tabela 14. Áreas das combinações das unidades de solo com as classes de declividade da microbacia.

\begin{tabular}{|c|c|c|c|}
\hline $\begin{array}{c}\text { Unidades } \\
\text { de solo }\end{array}$ & $\begin{array}{c}\text { Classes de } \\
\text { declividade }\end{array}$ & Hectares & $\%$ \\
\hline associação de solos podzólicos & $0-2 \%$ & 91,34 & 6,07 \\
\hline associação de solos podzólicos & $2-5 \%$ & 57,04 & 3,79 \\
\hline associação de solos podzólicos & $\mathbf{5 - 1 0} \%$ & $\mathbf{1 9 6 , 5 2}$ & $\mathbf{1 3 , 0 5}$ \\
\hline associação de solos podzólicos & $\mathbf{1 0 - 1 5 \%}$ & $\mathbf{2 1 5 , 2 9}$ & $\mathbf{1 4 , 3 0}$ \\
\hline associação de solos podzólicos & $>\mathbf{1 5} \%$ & $\mathbf{1 5 1 , 8 4}$ & $\mathbf{1 0 , 0 8}$ \\
\hline associação de solo cambissolo com solo aluvial & $0-2 \%$ & 31,97 & 2,12 \\
\hline associação de solo cambissolo com solo aluvial & $2-5 \%$ & 15,61 & 1,04 \\
\hline associação de solo cambissolo com solo aluvial & $5-10 \%$ & 5,12 & 0,34 \\
\hline associação de solo cambissolo com solo aluvial & $10-15 \%$ & 1,56 & 0,10 \\
\hline associação de solo cambissolo com solo aluvial & $>15 \%$ & 2,68 & 0,18 \\
\hline associação de solo litólico com solo podzólico & $0-2 \%$ & $\mathbf{7 5 , 2 0}$ & 4,99 \\
\hline associação de solo litólico com solo podzólico & $2-5 \%$ & 64,18 & 4,26 \\
\hline associação de solo litólico com solo podzólico & $\mathbf{5 - 1 0 \%}$ & $\mathbf{2 2 0 , 3 7}$ & $\mathbf{1 4 , 6 3}$ \\
\hline associação de solo litólico com solo podzólico & $\mathbf{1 0}-\mathbf{1 5} \%$ & $\mathbf{2 1 2 , 4 2}$ & $\mathbf{1 4 , 1 1}$ \\
\hline associação de solo litólico com solo podzólico & $\mathbf{> 1 5} \%$ & $\mathbf{1 6 4 , 7 3}$ & $\mathbf{1 0 , 9 4}$ \\
\hline Total & & 1505,85 & 100,00 \\
\hline \multicolumn{2}{|c|}{} \\
\hline
\end{tabular}




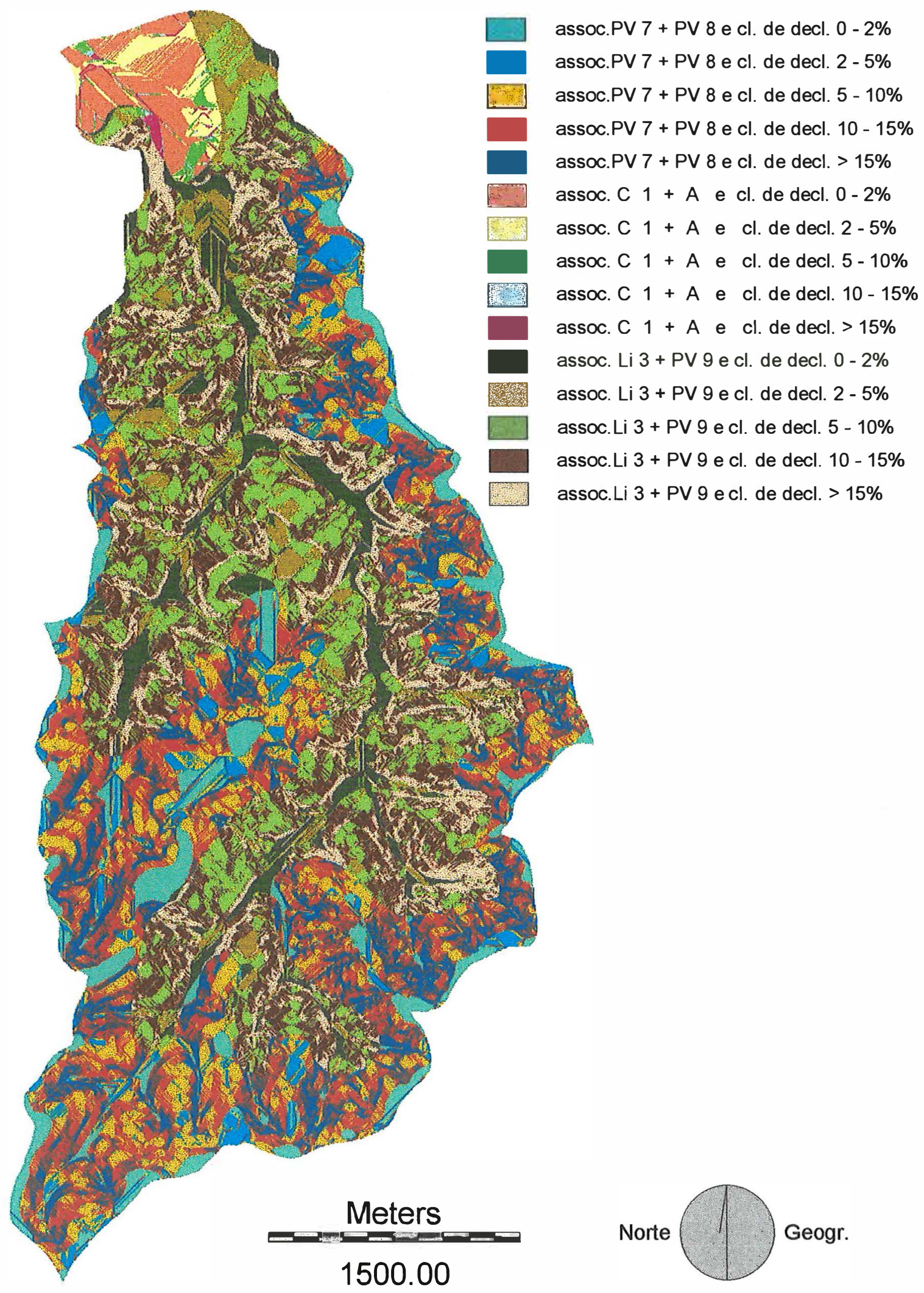

Figura 6. Combinações das unidades de solo com as classes de declividade da microbacia. 


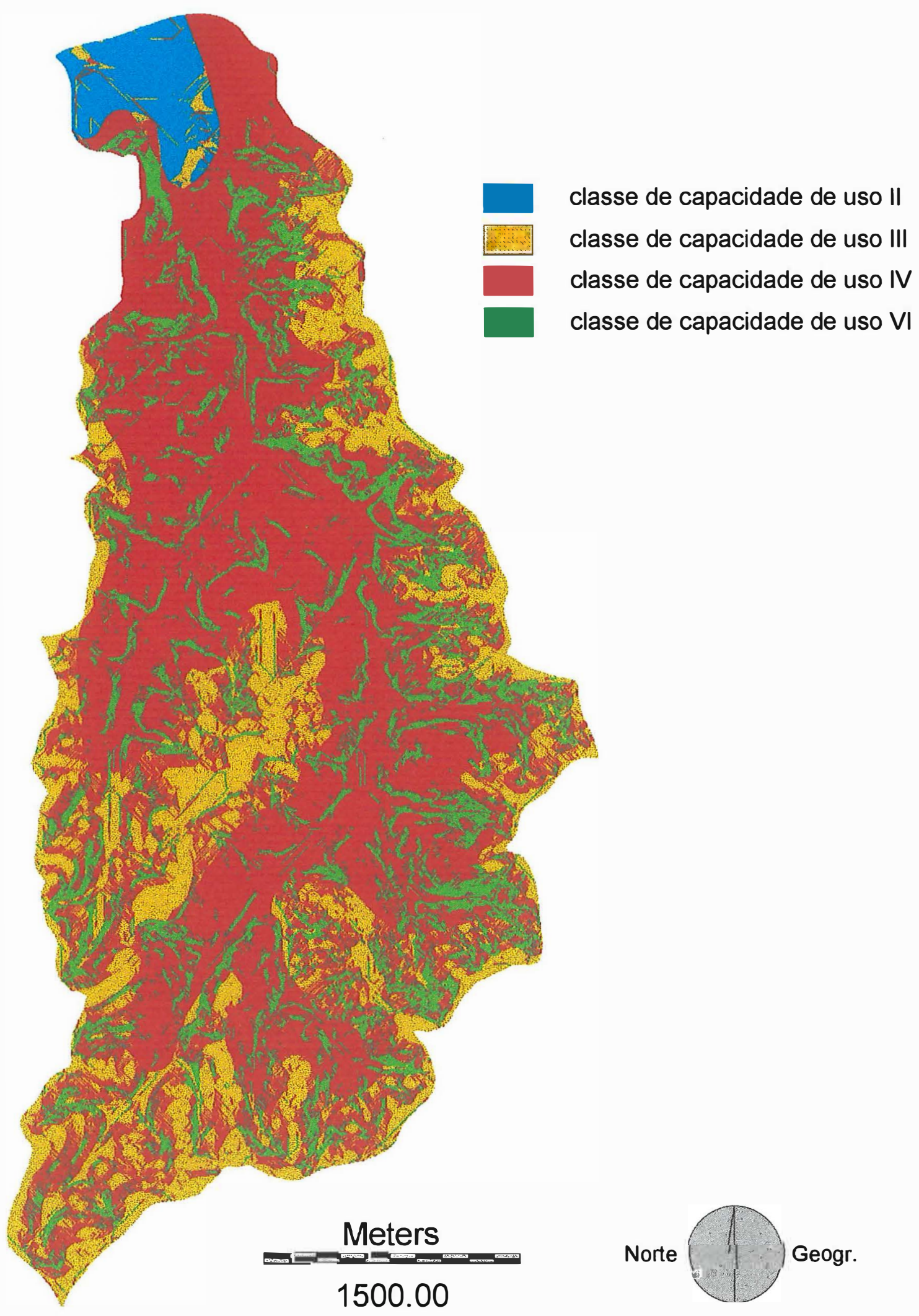

Figura 7. Classes de capacidade de uso da microbacia hidrográfica do Ribeirão Pau d'Alhinho. 
Tabela 15. Áreas das classes de capacidade de uso das terras da microbacia.

\begin{tabular}{|c|c|c|}
\hline Classes de capacidade de uso & Hectares & $\%$ \\
\hline II & 47,58 & 3,16 \\
\hline III & 351,58 & 23,35 \\
\hline IV & $\mathbf{7 9 0 , 1 3}$ & $\mathbf{5 2 , 4 7}$ \\
\hline VI & 316,57 & 21,02 \\
\hline Total & 1505,85 & 100,00 \\
\hline
\end{tabular}

Os dados apresentados comprovaram que a área de estudo contém uma parte considerável de terras menos nobres, que, segundo Sparovek \& Lepsch (1998), são terras de baixa aptidão para cultivo intensivo.

\subsection{Análise temporal do uso da terra}

\subsubsection{Situação da microbacia em 1995}

Apesar das condições restritivas de uso da microbacia para agricultura intensiva, pode-se apreender facilmente da Figura 8 que a cultura da cana-de açúcar predominava em 1995 na microbacia (aproximadamente 55\% da área total). Isso refletia, na época, a disponibilidade de um grande mercado consumidor na região, que direcionava as atividades dos proprietários rurais e motivava, inclusive, a ocupação de áreas menos nobres. Tal fato já havia sido observado por Ranieri \& Sparovek (1993) e Muramoto (1993).

As características de ocupação da microbacia, em 1995, pela cultura da cana-de-açúcar são confirmadas pelos dados da Tabela 16, obtidos do cruzamento do mapa da cultura canavieira com os mapas das combinações de unidades de solo e declividade. É possível notar que, somando-se os dados de área das terras com classe de capacidade de uso IV, uso com risco, com os da classe VI, superutilizadas, obtem-se o resultado de 601,70 ha de terras com uso inadequado $(72,73 \%$ das terras ocupadas com cana em 1995). Por outro lado, dos 399,16 ha de terras aptas para agricultura intensiva 




Figura 8. Uso da terra na microbacia em 1995. 
Tabela 16. Áreas das combinações de unidades de solo com classes de declividade e de classes de capacidade de uso ocupadas com a cultura da cana-de-açúcar em 1995.

\begin{tabular}{|c|c|c|c|c|}
\hline $\begin{array}{c}\text { Unidades } \\
\text { de solo }\end{array}$ & $\begin{array}{c}\text { Classes de } \\
\text { declividade }\end{array}$ & ccu & Hectares & \% \\
\hline associação de solos podzólicos & $0-2 \%$ & III & 52,62 & 6,36 \\
\hline associação de solos podzólicos & $2-5 \%$ & III & 32,39 & 3,92 \\
\hline associação de solos podzólicos & $\mathbf{5 - 1 0} \%$ & III & $\mathbf{1 1 4 , 4 0}$ & $\mathbf{1 3 , 8 3}$ \\
\hline associação de solos podzólicos & $\mathbf{1 0}-\mathbf{1 5} \%$ & IV & $\mathbf{1 1 5 , 9 7}$ & $\mathbf{1 4 , 0 2}$ \\
\hline associação de solos podzólicos & $>\mathbf{1 5} \%$ & VI & $\mathbf{7 1 , 4 7}$ & $\mathbf{8 , 6 4}$ \\
\hline associação de solo cambissolo com solo aluvial & $0-2 \%$ & II & 13,39 & 1,62 \\
\hline associação de solo cambissolo com solo aluvial & $2-5 \%$ & II & 8,19 & 0,99 \\
\hline associação de solo cambissolo com solo aluvial & $5-10 \%$ & III & 3,82 & 0,46 \\
\hline associação de solo cambissolo com solo aluvial & $10-15 \%$ & III & 0,77 & 0,09 \\
\hline associação de solo cambissolo com solo aluvial & $>15 \%$ & IV & 1,15 & 0,14 \\
\hline associação de solo litólico com solo podzólico & $0-2 \%$ & IV & 15,57 & 1,88 \\
\hline associação de solo litólico com solo podzólico & $2-5 \%$ & IV & 36,47 & 4,41 \\
\hline associação de solo litólico com solo podzólico & $\mathbf{5}-\mathbf{1 0} \%$ & IV & $\mathbf{1 4 0 , 0 4}$ & $\mathbf{1 6 , 9 3}$ \\
\hline associação de solo litólico com solo podzólico & $\mathbf{1 0}-\mathbf{1 5} \%$ & IV & $\mathbf{1 3 2 , 4 0}$ & $\mathbf{1 6 , 0 0}$ \\
\hline associação de solo litólico com solo podzólico & $>\mathbf{1 5} \%$ & VI & $\mathbf{8 8 , 6 3}$ & $\mathbf{1 0 , 7 1}$ \\
\hline \multicolumn{2}{|c|}{ Total } & & 827,25 & 100,00 \\
\hline
\end{tabular}

(classes II e III de capacidade de uso, Tabela 15$)$, somente 225,58 ha $(56,51 \%)$ eram cultivados em 1995 com cana-de-açúcar.

A restrição de grande parte da microbacia para agricultura intensiva ficou também evidenciada pela considerável extensão da categoria pasto em 1995 (aproximadamente 28,5\%). Ranieri \& Sparovek (1993) afirmaram que o pasto ocupava em 1991, no Município de Piracicaba, em geral, áreas com claras limitações de solo ou topografia. No caso da microbacia hidrográfica do Ribeirão Pau d'Alhinho, ele estava localizado, em 1995, principalmente, às margens dos cursos d'água e em suas cabeceiras (229,12 ha com classe de capacidade de uso IV e 100,59 ha com VI). 


\subsubsection{Usos anteriores das terras da microbacia}

O padrão de uso da terra em 1995 tendeu a repetir o dos anos anteriores, especialmente em 1978 e 1962, como é possível ser observado nas Figuras 9 e 10. Em 1940, no entanto, as culturas anuais é que se destacavam (Figura 11). Assim, apesar da predominância de solos com baixa aptidão para cultivo intensivo, a microbacia teve uma certa tradição em agricultura, em particular com a cultura da cana-de-açúcar. Os dados da Tabela 17 corroboram os dados gráficos.

Tabela 17. Áreas das diferentes categorias de uso da terra.

\begin{tabular}{|c|c|c|c|c|c|c|c|c|}
\hline \multirow{2}{*}{ Categorias } & \multicolumn{2}{|c|}{1995} & \multicolumn{2}{c|}{1978} & \multicolumn{2}{c|}{1962} & \multicolumn{2}{c|}{1940} \\
\cline { 2 - 9 } & Hectares & $\%$ & Hectares & \% & Hectares & $\%$ & Hectares & $\%$ \\
\hline v.nat. & 121,28 & 8,05 & 165,14 & 10,97 & 188,93 & 12,55 & 186,99 & 12,42 \\
\hline reflor. & 11,55 & 0,77 & 30,47 & 2,02 & 161,26 & 10,71 & 6,04 & 0,40 \\
\hline cana & 827,25 & $\mathbf{5 4 , 9 4}$ & 782,93 & $\mathbf{5 1 , 9 9}$ & 467,29 & $\mathbf{3 1 , 0 3}$ & 14,24 & 0,95 \\
\hline c.an. & 34,74 & 2,31 & 12,42 & 0,82 & 23,84 & 1,58 & 426,43 & $\mathbf{2 8 , 3 2}$ \\
\hline c.prm. & 0 & 0 & 73,79 & 4,90 & 80,43 & 5,34 & 136,60 & 9,07 \\
\hline pasto & 427,48 & 28,39 & 402,02 & 26,70 & 567,57 & 37,69 & 718,43 & 47,71 \\
\hline á.sede & 40,75 & 2,71 & 37,46 & 2,49 & 14,10 & 0,94 & 17,14 & 1,14 \\
\hline l.rural & 23,89 & 1,59 & 0 & 0 & 0 & 0 & 0 & 0 \\
\hline l.urb. & 4,83 & 0,32 & 0 & 0 & 0 & 0 & 0 & 0 \\
\hline repres. & 7,88 & 0,52 & 1,63 & 0,11 & 0 & 0 & 0 & 0 \\
\hline miner. & 6,21 & 0,41 & 0 & 0 & 2,43 & 0,16 & 0 & 0 \\
\hline Total & 1505,85 & 100,00 & 1505,85 & 100,00 & 1505,85 & 100,00 & 1505,85 & 100,00 \\
\hline
\end{tabular}

Sparovek \& Lepsch (1998) esclareceram que esse fenômeno ocorreu devido às características topográficas da microbacia, bem como de sua proximidade às usinas canavieiras a partir da década de 1950 (Angulo Filho, 1981).

Por outro lado, a microbacia hidrográfica do Ribeirão Pau d'Alhinho não acompanhou as tendências de expansão da cultura canavieira no Município de Piracicaba. Segundo Sparovek \& Lepsch (1998), Angulo Filho (1981) e Audi (1965), a cultura canavieira ocupava nesse município, em 1962, predominantemente, terras mais nobres, 


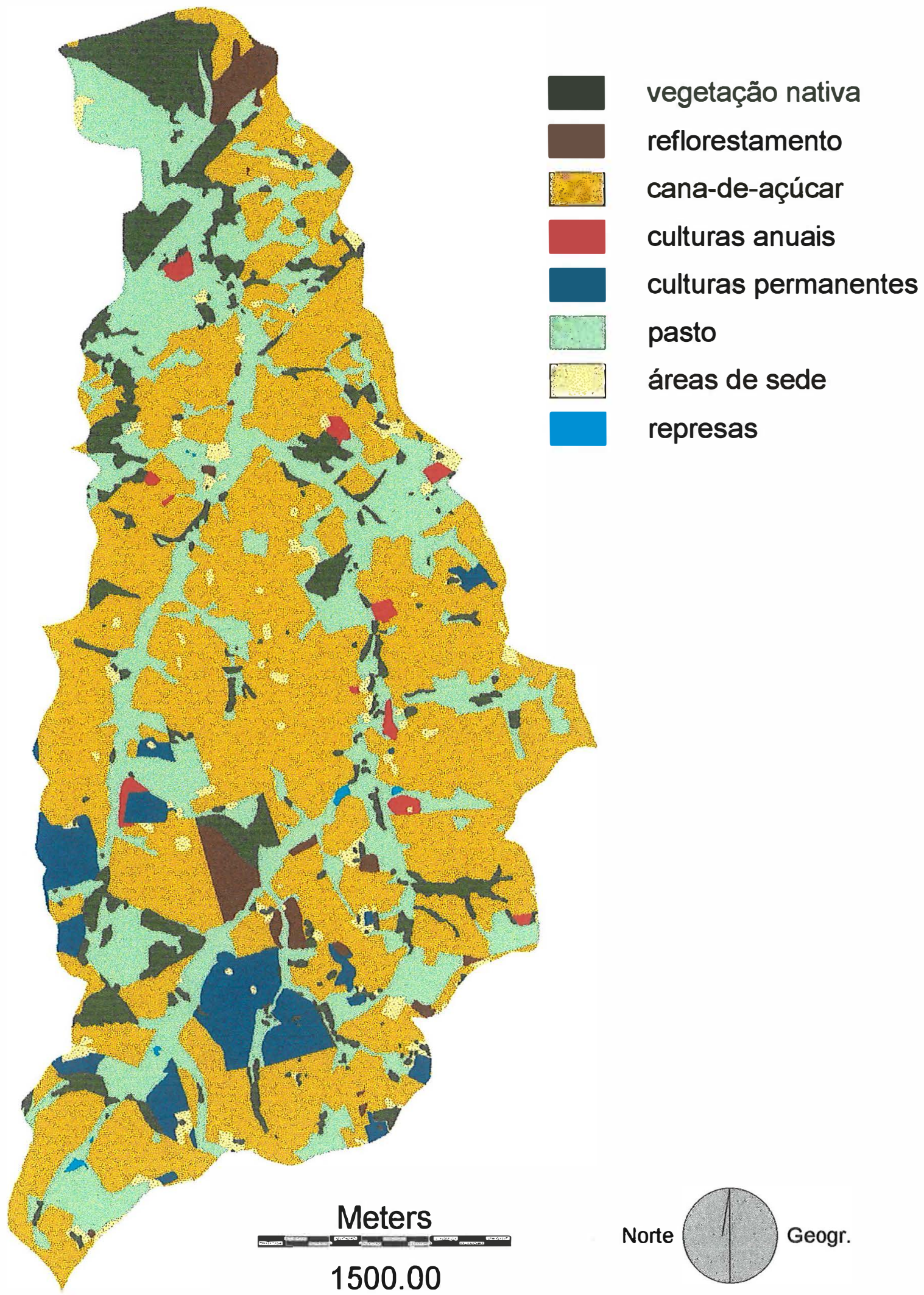

Figura 9. Uso da terra na microbacia em 1978. 


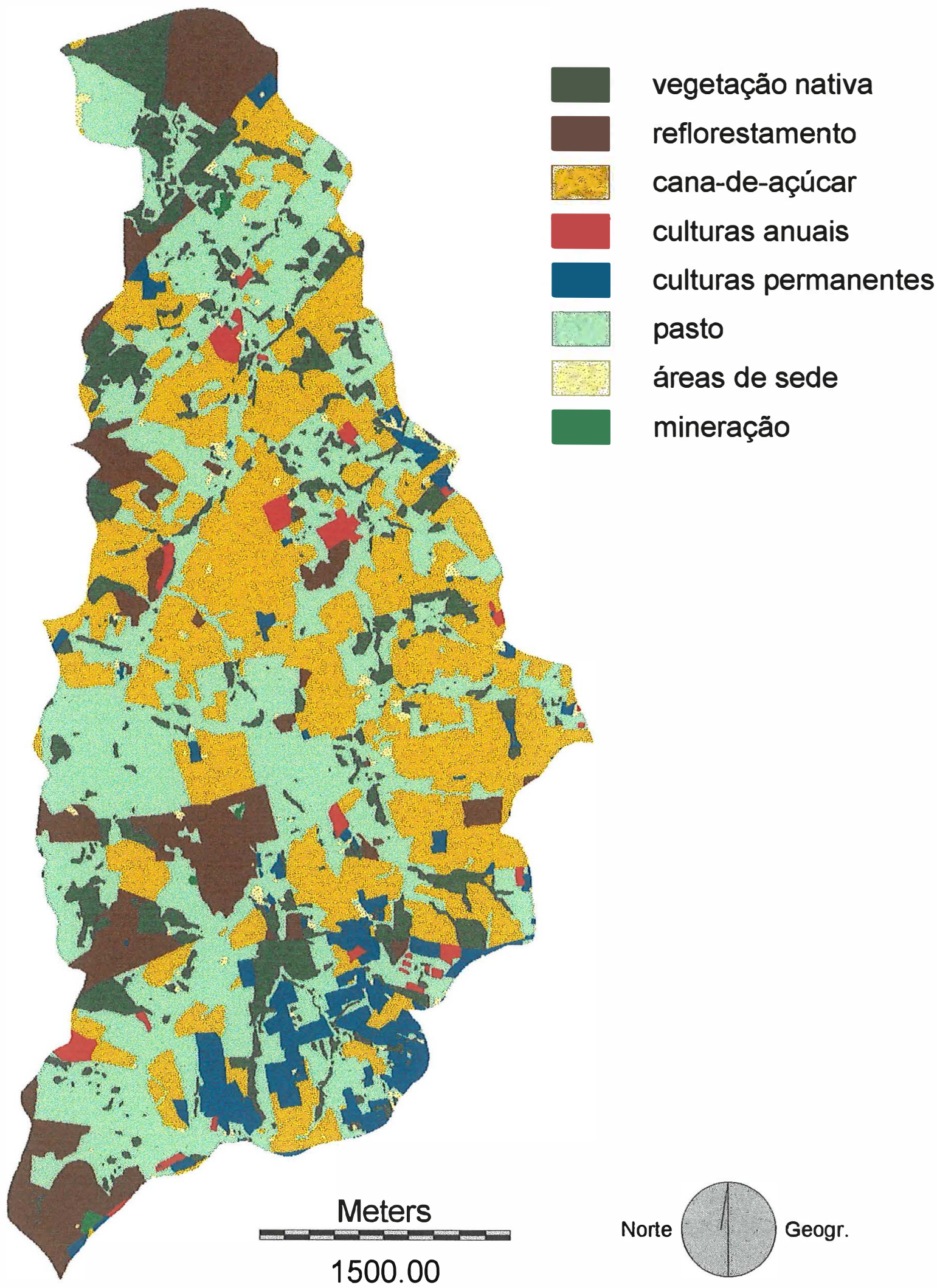

Figura 10. Uso da terra na microbacia em 1962. 


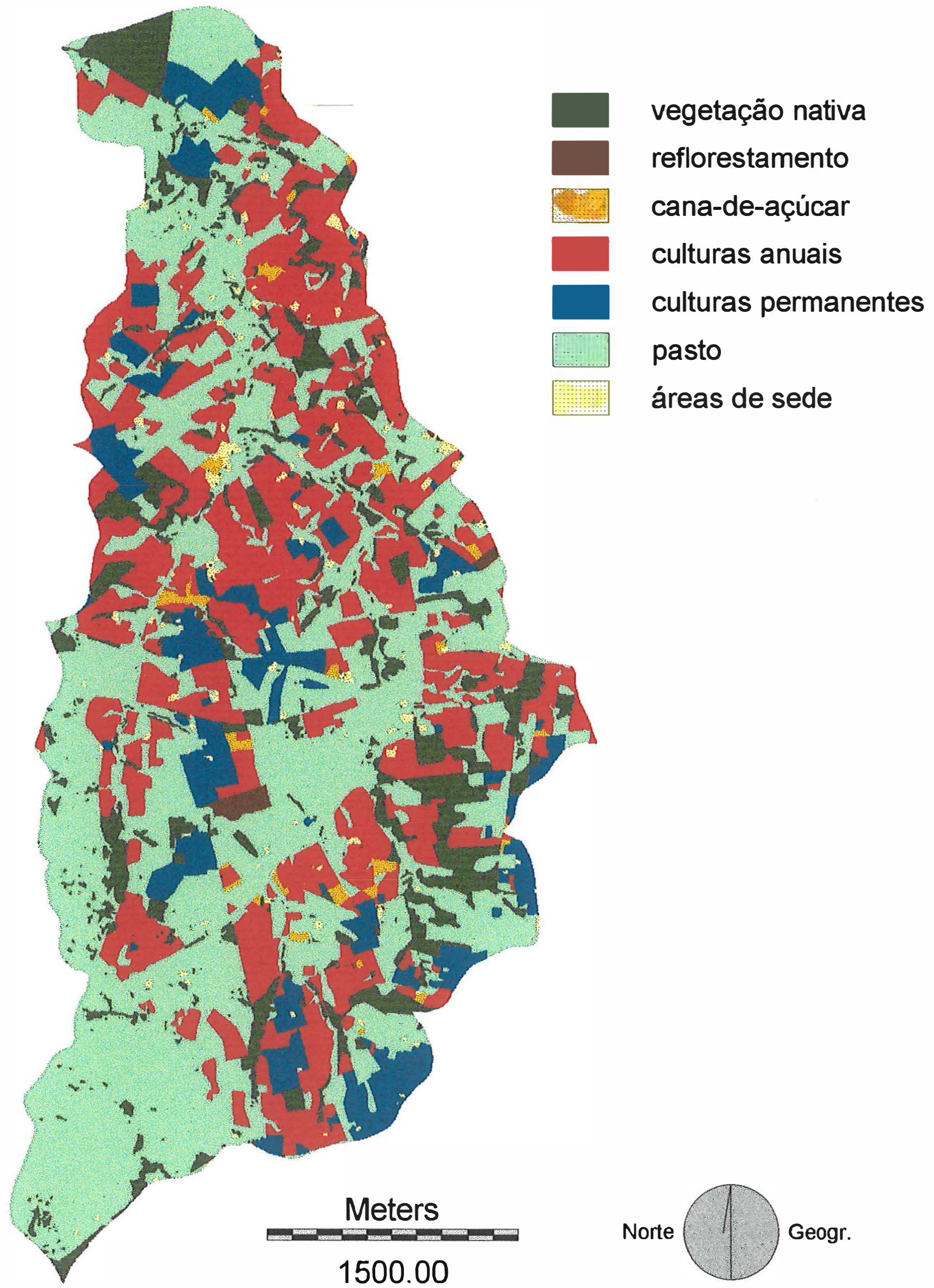

Figura 11. Uso da terra na microbacia em 1940. 
ao passo que, na microbacia em questão, a cultura canavieira já ocupava terras com menor aptidão agrícola. Ao mesmo tempo, não ocupava completamente as terras mais indicadas à agricultura. Os dados a seguir constatam esse fato: dos 399,16 ha de terras aptas para cultivo intensivo, 243,89 ha eram agricultados em 1978, 152,06 ha em 1962 e 160,77 ha em 1940, o que mostra um avanço tardio e incompleto sobre as terras mais nobres dessa microbacia.

Já os dados da Tabela 18 e dos mapas representados nas Figuras 12, 13, 14 e 15 mostram que uma parte considerável da microbacia hidrográfica do Ribeirão Pau d'Alhinho já era usada há tempos inadequadamente, com porcentagens sempre superiores às do Município de Piracicaba (Muramoto, 1993).

Tabela 18. Áreas de adequação de uso da microbacia nas diferentes datas.

\begin{tabular}{|c|c|c|c|c|c|c|c|c|}
\hline $\begin{array}{c}\text { Adequação } \\
\text { de uso }\end{array}$ & \multicolumn{2}{|c|}{1995} & \multicolumn{2}{c|}{1978} & \multicolumn{2}{c|}{1962} & \multicolumn{2}{c|}{1940} \\
\cline { 2 - 9 } & Hectares & \% & Hectares & \% & Hectares & \% & Hectares & \% \\
\hline Adequado & 692,42 & 45,98 & 757,48 & 50,30 & 881,19 & 58,52 & 887,46 & 58,93 \\
\hline Subutilizado & 100,28 & 6,66 & 84,04 & 5,58 & 188,62 & 12,53 & 184,77 & 12,27 \\
\hline Risco & 441,59 & $\mathbf{2 9 , 3 3}$ & 412,42 & $\mathbf{2 7 , 3 9}$ & 261,81 & $\mathbf{1 7 , 3 9}$ & 7,18 & $\mathbf{0 , 4 8}$ \\
\hline Superutilizado & 188,00 & $\mathbf{1 2 , 4 8}$ & 212,82 & $\mathbf{1 4 , 1 3}$ & 157,70 & $\mathbf{1 0 , 4 7}$ & 409,31 & $\mathbf{2 7 , 1 8}$ \\
\hline Não avaliado & 83,56 & 5,55 & 39,10 & 2,60 & 16,53 & 1,10 & 17,14 & 1,14 \\
\hline Total & 1505,85 & 100,00 & 1505,85 & 100,00 & 1505,85 & 100,00 & 1505,85 & 100,00 \\
\hline
\end{tabular}

Em contrapartida, uma parte também expressiva da microbacia foi usada adequadamente no período estudado, graças, principalmente, à extensão da categoria pasto.

\subsubsection{Usos anteriores das terras agricultadas em 1995}

A partir do isolamento das terras agricultadas em 1995 foi possível constatar que aquela tradição com agricultura tendeu a ocupar as mesmas áreas nas datas 


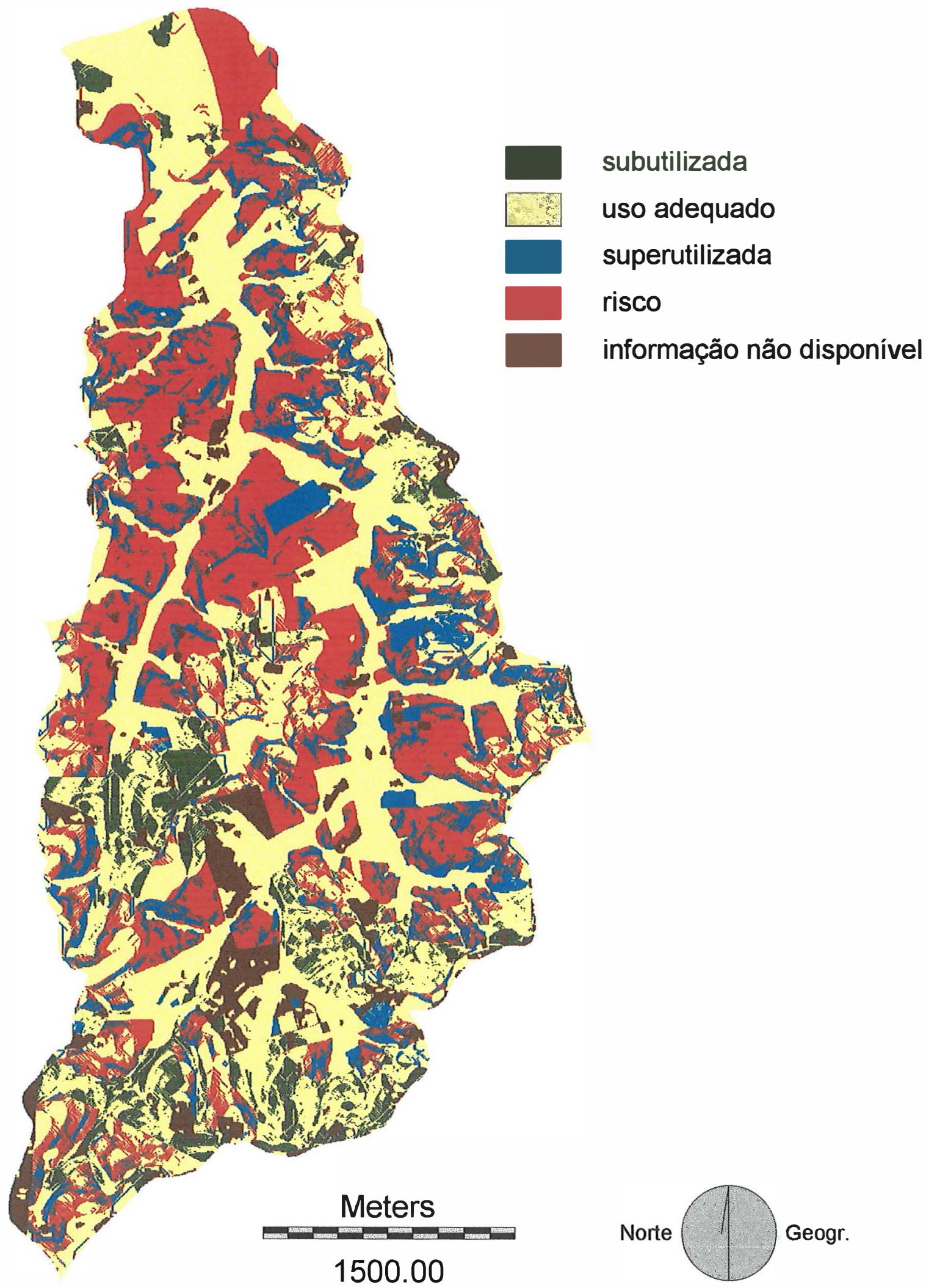

Figura 12. Adequação de uso das terras da microbacia em 1995. 


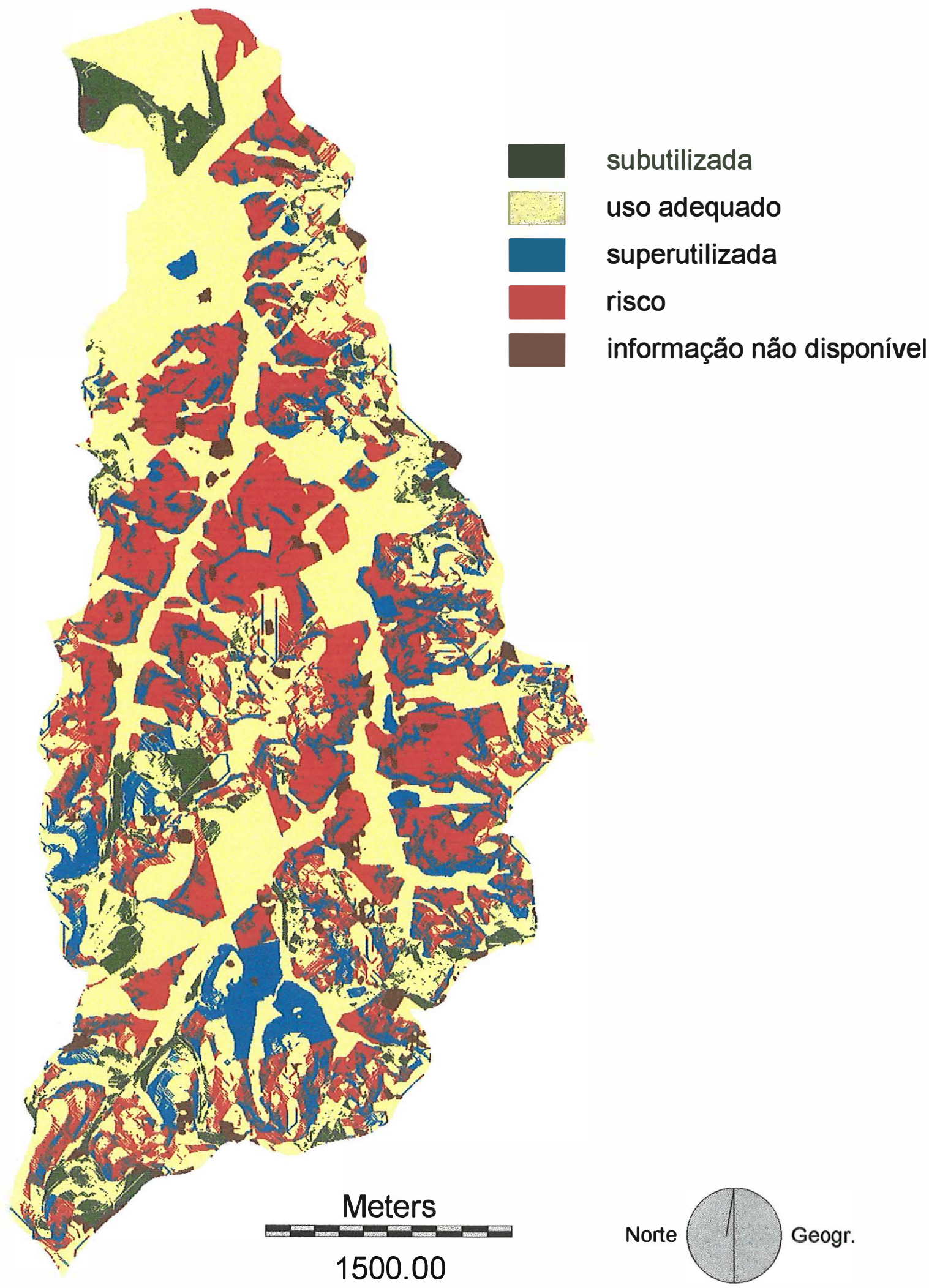

Figura 13. Adequação de uso das terras da microbacia em 1978. 


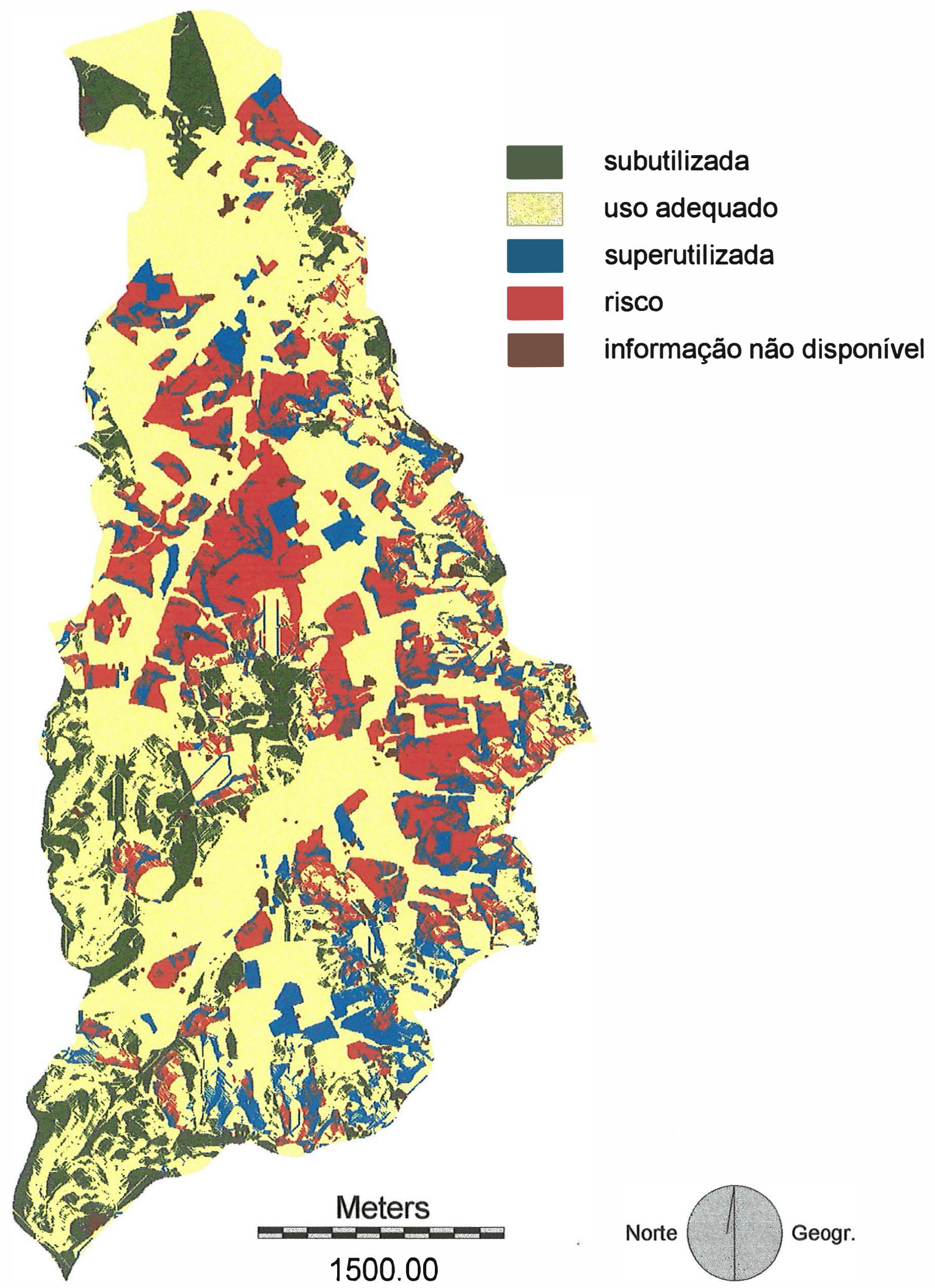

Figura 14. Adequação de uso das terras da microbacia em 1962. 


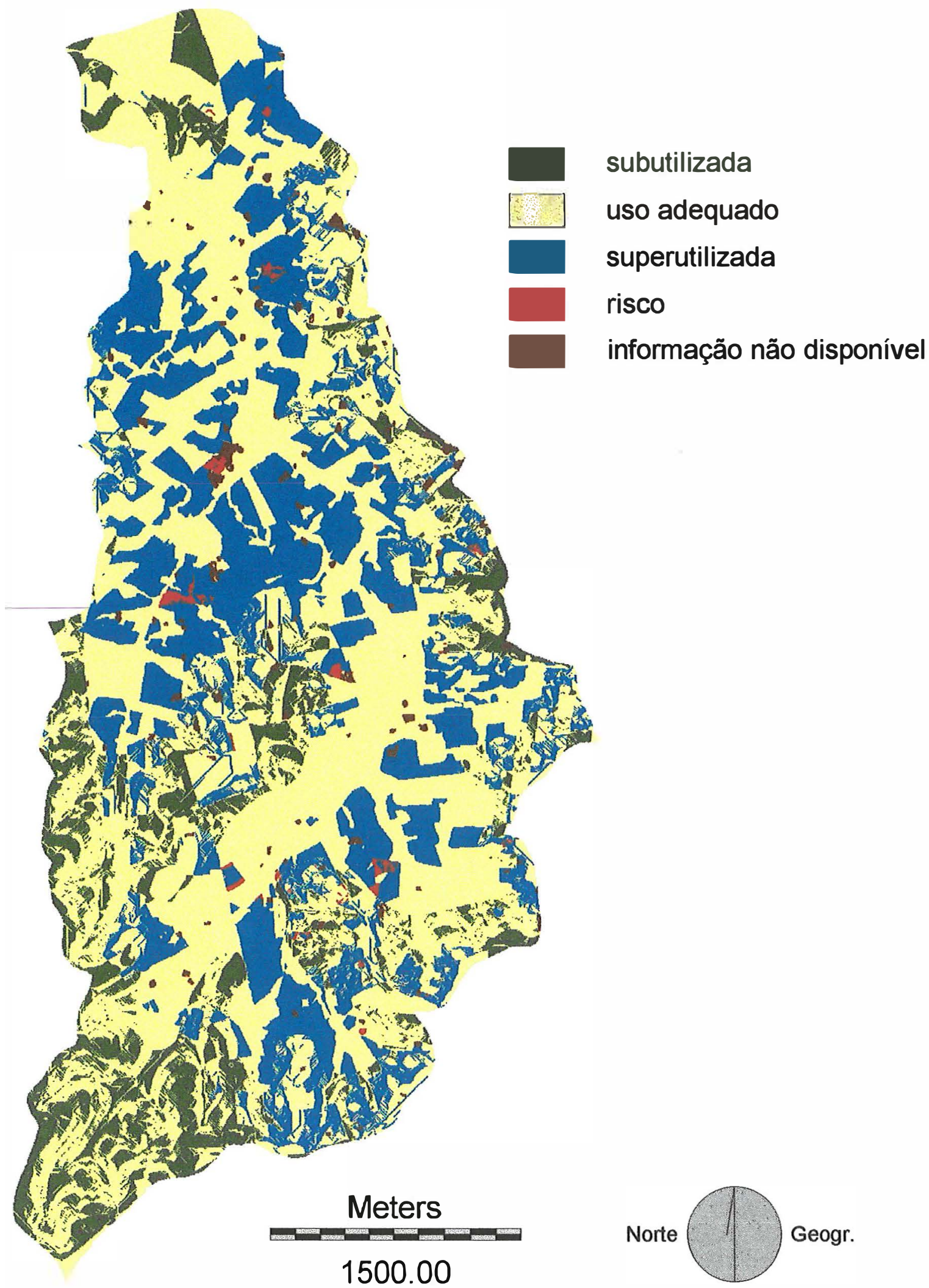

Figura 15. Adequação de uso das terras da microbacia em 1940. 
estudadas, como é possível observar nas Figuras 16, 17, 18 e 19. Os dados da Tabela 19 reforçam essa tendência.

Tabela 19. Áreas das categorias de uso em 1995, 1978, 1962 e 1940 das terras agricultadas em 1995.

\begin{tabular}{|c|c|c|c|c|c|c|c|c|}
\hline \multirow{2}{*}{ Categorias } & \multicolumn{3}{|c|}{ Agricultura 95 x 1995 } & \multicolumn{3}{|c|}{ Agricultura 95 x 1978 } & \multicolumn{3}{|c|}{ Agricultura 95 x 1962 } & \multicolumn{3}{|c|}{ Agricultura 95 x 1940 } \\
\cline { 2 - 9 } & Hectares & $\%$ & Hectares & $\%$ & Hectares & $\%$ & Hectares & $\%$ \\
\hline v.nat. & 0 & 0 & 57,75 & 6,70 & 75,83 & 8,80 & 82,66 & 9,59 \\
\hline reflor. & 0 & 0 & 12,73 & 1,48 & 102,29 & 11,87 & 1,57 & 0,18 \\
\hline cana & 827,25 & $\mathbf{9 5 , 9 7}$ & 604,59 & $\mathbf{7 0 , 1 4}$ & 368,01 & $\mathbf{4 2 , 6 9}$ & 9,14 & 1,06 \\
\hline c.an. & 34,74 & 4,03 & 7,76 & 0,90 & 16,53 & 1,92 & 296,63 & $\mathbf{3 4 , 4 1}$ \\
\hline c.prm. & 0 & 0 & 23,77 & 2,76 & 32,67 & 3,79 & 82,03 & 9,52 \\
\hline pasto & 0 & 0 & 145,89 & 16,92 & 262,55 & 30,46 & 382,34 & 44,36 \\
\hline á.sede & 0 & 0 & 9,50 & 1,10 & 3,46 & 0,40 & 7,63 & 0,88 \\
\hline miner. & 0 & 0 & 0 & 0 & 0,66 & 0,08 & 0 & 0 \\
\hline Total & 861,99 & 100,00 & 861,99 & 100,00 & 861,99 & 100,00 & 861,99 & 100,00 \\
\hline
\end{tabular}

Observa-se que, dos 57,25\% das terras ocupadas com agricultura em 1995 (Tabela 17), dos quais 95,97\% eram cana-de-açucar (Tabela 19), 73,80\% já eram agricultura em 1978 (70,14\% só de cana-de-açucar); 48,40\% em 1962 (42,69\% com cana) e 44,99\% em 1940 (34,41\%, culturas anuais).

Constata-se, sobretudo, que a agricultura praticada em cada data tendeu a se concentrar nas terras que eram agricultadas em 1995. Assim, dividindo-se os dados somados das categorias cana-de-açúcar, culturas anuais e culturas permanentes, em hectares, da Tabela 19, pelos também somados da Tabela 17 e multiplicando-se os resultados por 100, as áreas agricultadas em cada data, exclusivamente pertencentes à área das terras agricultadas em 1995, representavam uma porcentagem expressiva do total de agricultura em cada uma das datas enfocadas, de 1995 a 1940: 100,00\%, $73,19 \%, 72,99 \%$ e $67,18 \%$. Então, a maior parte das terras com uso inadequado nas quatro datas concentrou-se nas terras agricultadas em 1995, fato que pode ser comprovado pela comparação entre as Tabelas 20 e 18. Portanto, é possível inferir que as 


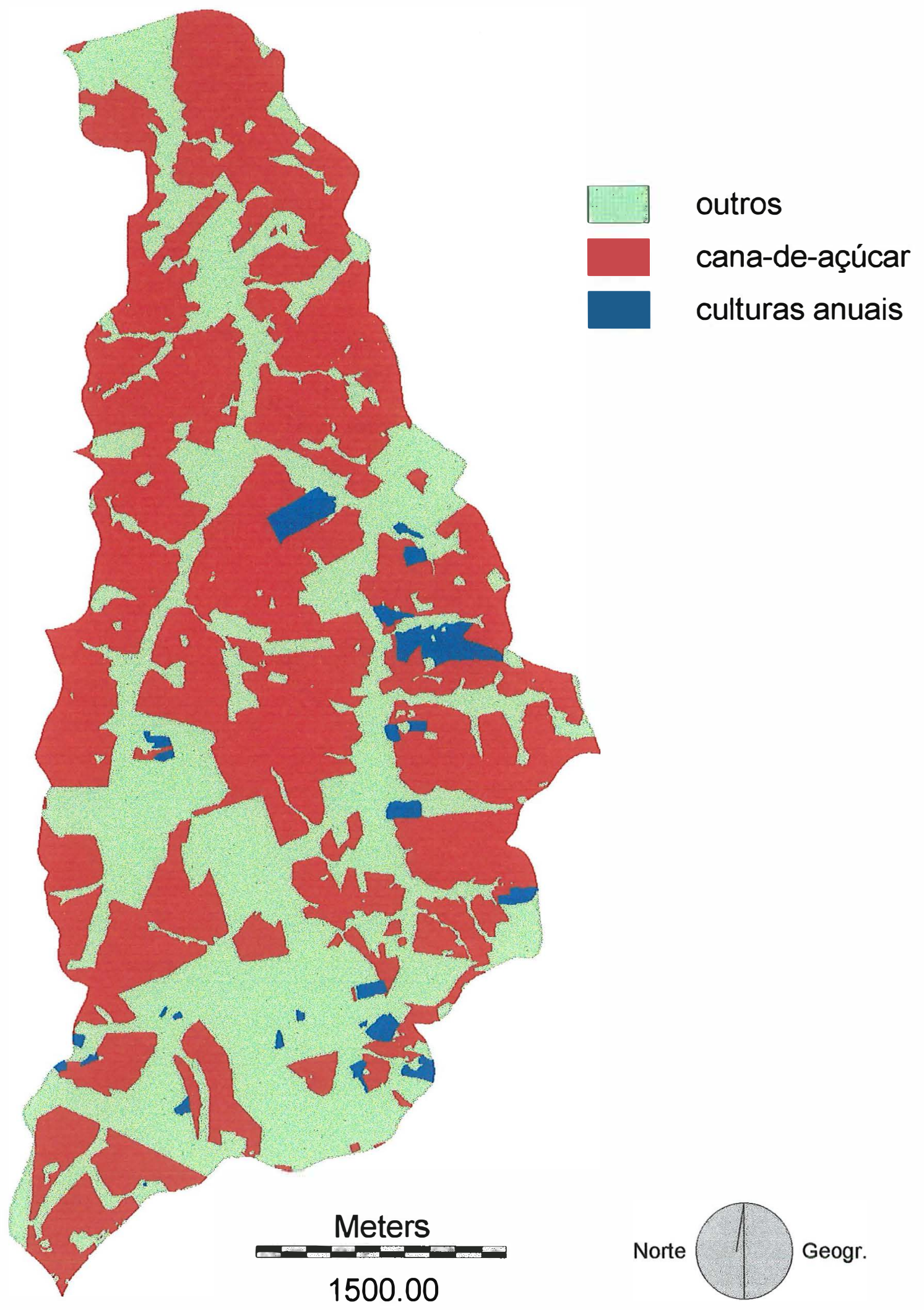

Figura 16. Uso das terras agricultadas em 1995. 


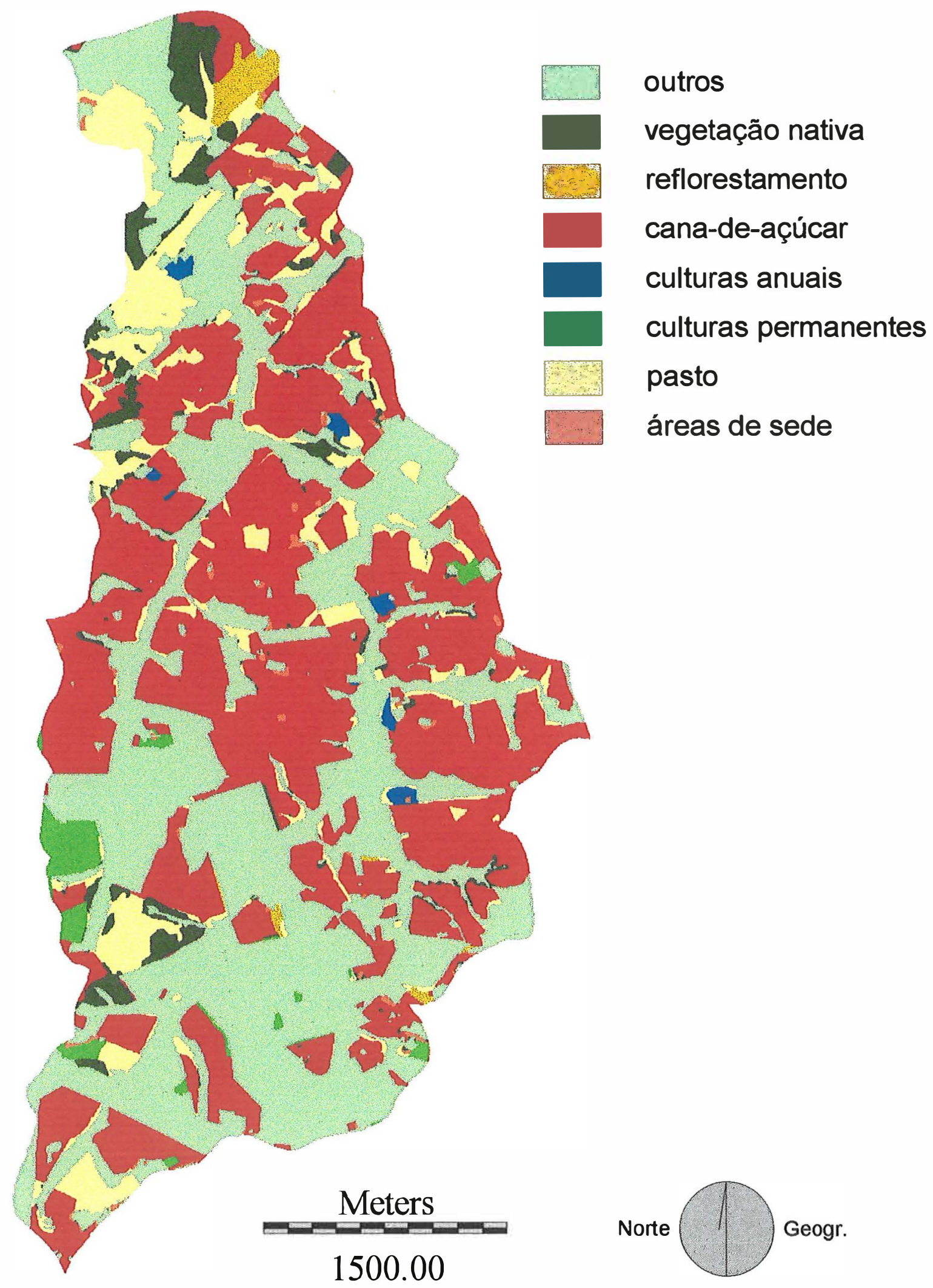

Figura 17. Uso em 1978 das terras agricultadas em 1995. 


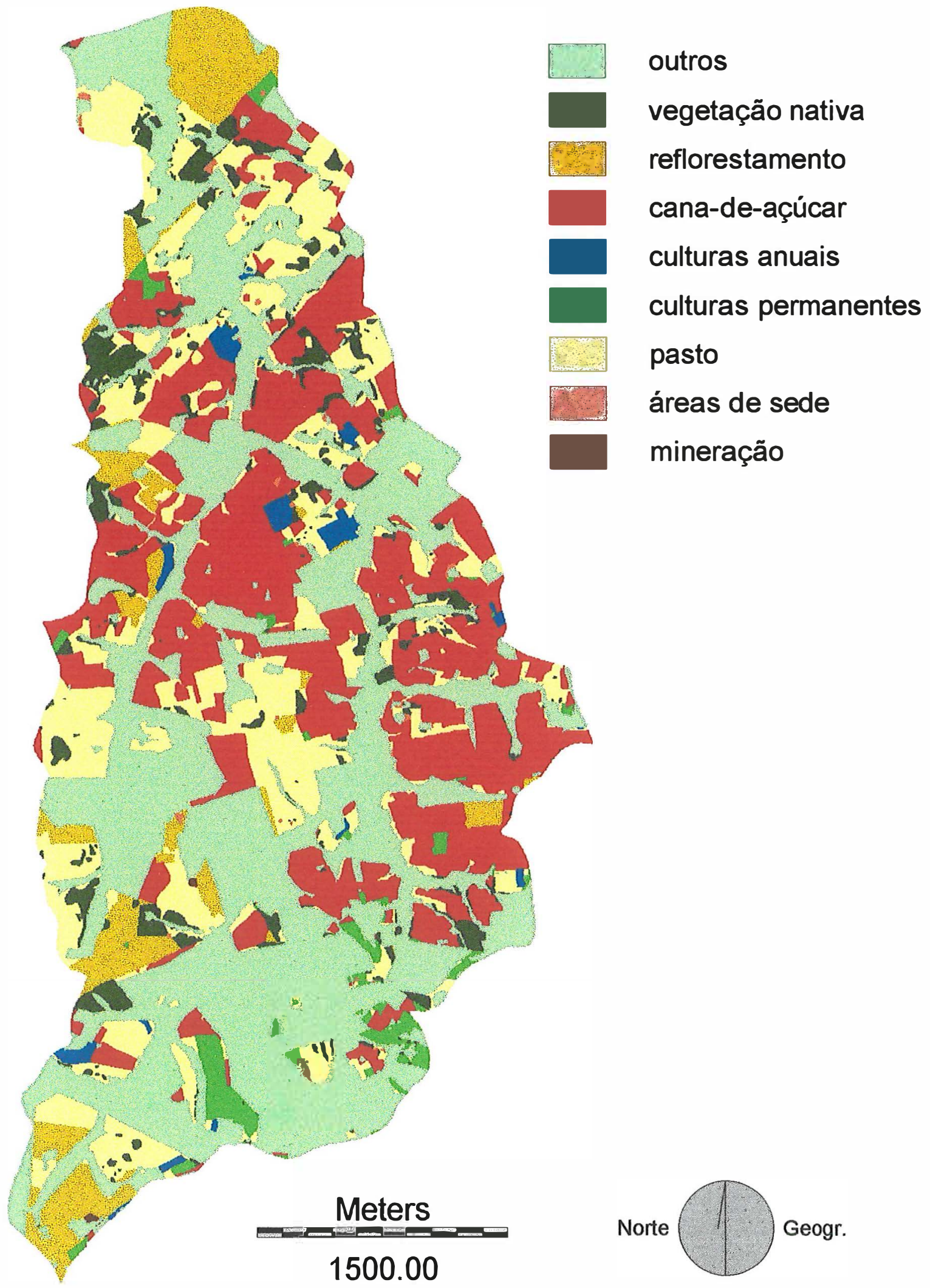

Figura 18. Uso em 1962 das terras agricultadas em 1995. 


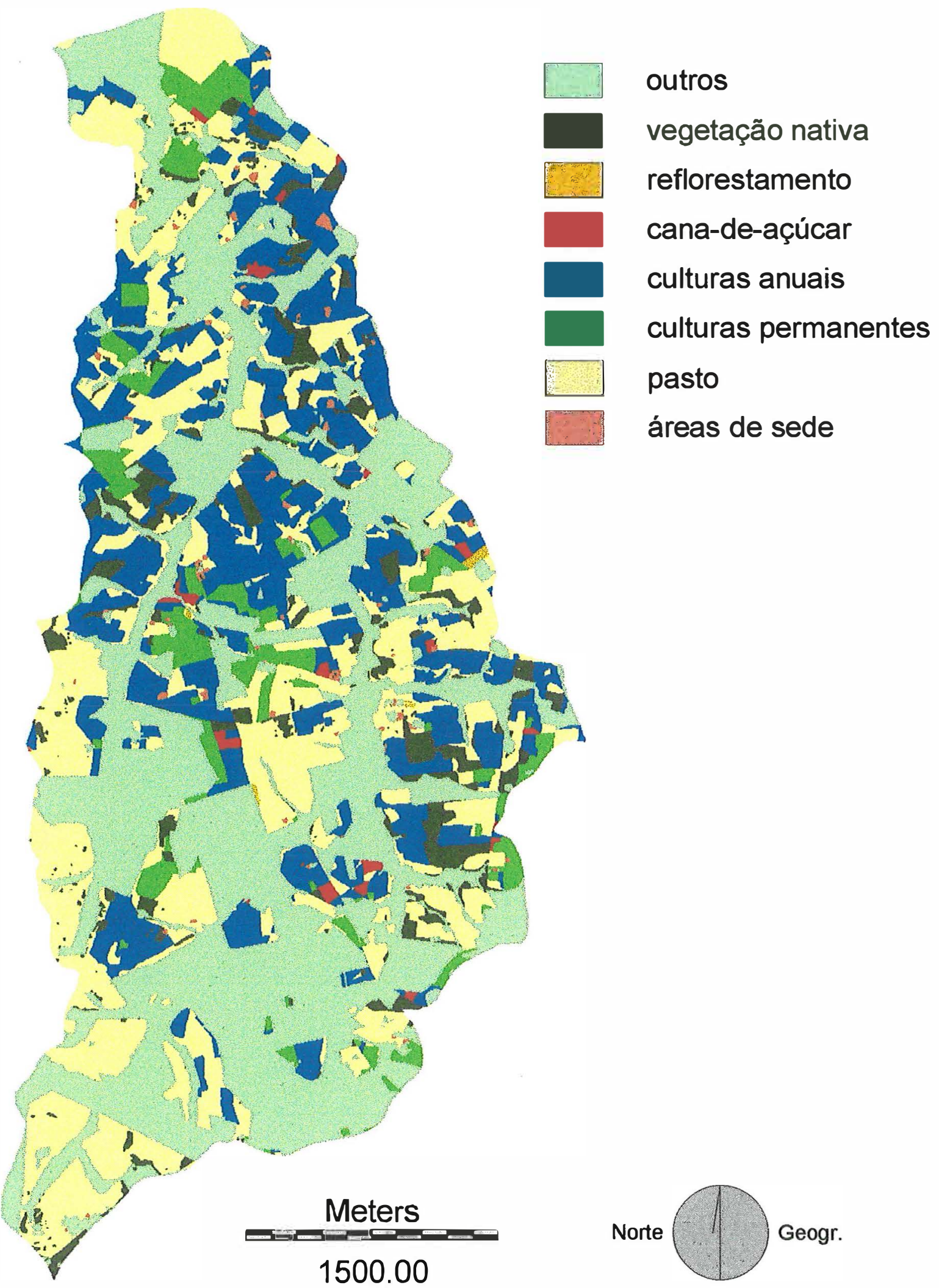

Figura 19. Uso em 1940 das terras agricultadas em 1995. 
Tabela 20. Áreas de adequação de uso em 1995, 1978, 1962 e 1940 das terras agricultadas em 1995.

\begin{tabular}{|c|c|c|c|c|c|c|c|c|c|c|}
\hline Categorias & Adq. & \multicolumn{3}{|c|}{1995} & \multicolumn{2}{c|}{1978} & \multicolumn{2}{c|}{1962} & \multicolumn{2}{c|}{1940} \\
de uso & uso & Hectares & $\%$ & Hectares & \% & Hectares & Hectares & $\%$ \\
\hline v.nat. & A & 0 & 0 & 57,75 & 6,70 & 75,83 & 8,80 & 82,66 & 9,59 \\
\hline reflor. & SB & 0 & 0 & 1,70 & 0,20 & 35,81 & 4,15 & 0,60 & 0,07 \\
\hline reflor. & A & 0 & 0 & 11,04 & 1,28 & 66,48 & 7,71 & 0,97 & 0,11 \\
\hline cana & A & 225,56 & 26,17 & 163,19 & 18,93 & 86,91 & 10,08 & 3,57 & 0,41 \\
\hline cana & R & 441,59 & $\mathbf{5 1 , 2 3}$ & 329,01 & $\mathbf{3 8 , 1 7}$ & 212,09 & $\mathbf{2 4 , 6 0}$ & 3,85 & 0,45 \\
\hline cana & SP & 160,09 & $\mathbf{1 8 , 5 7}$ & 112,39 & $\mathbf{1 3 , 0 4}$ & 69,02 & $\mathbf{8 , 0 1}$ & 1,73 & 0,20 \\
\hline c.an. & A & 6,84 & 0,79 & 0,86 & 0,10 & 3,09 & 0,36 & 68,57 & 7,95 \\
\hline c.an. & SP & 27,91 & 3,24 & 6,90 & 0,80 & 13,43 & 1,56 & 228,06 & $\mathbf{2 6 , 4 6}$ \\
\hline c.prm. & A & 0 & 0 & 11,19 & 1,30 & 15,48 & 1,80 & 37,22 & 4,32 \\
\hline c.prm. & SP & 0 & 0 & 12,58 & 1,46 & 17,20 & 1,99 & 44,81 & 5,20 \\
\hline pasto & SB & 0 & 0 & 32,29 & 3,75 & 72,75 & 8,44 & 101,52 & 11,78 \\
\hline pasto & A & 0 & 0 & 113,60 & 13,18 & 189,80 & 22,02 & 280,82 & 32,58 \\
\hline outros & - & 0 & 0 & 9,50 & 1,10 & 4,12 & 0,48 & 7,63 & 0,88 \\
\hline Total & & 861,99 & 100,00 & 861,99 & 100,00 & 861,99 & 100,00 & 861,99 & 100,00 \\
\hline
\end{tabular}

áreas potencialmente mais degradadas da microbacia encontram-se nas terras agricultadas em 1995.

E, dentre essas áreas com maior potencial de degradação, destaca-se a que foi usada de forma sistemática e inadequada com agricultura nas quatro datas. Ela perfaz 154,41 ha, ou seja, 17,91\% das terras agricultadas em 1995 ou 10,25\% da microbacia inteira, cuja distribuição pode ser visualizada na Figura 20 e Tabela 21. Logo, é uma área que carece de uma mudança urgente de ocupação. Estudos posteriores poderiam avaliar o grau de degradação e indicar um uso mais oportuno, como fez Bertolami (1997). Em tempo, vale comentar que esse autor quantificou o grau de impacto do uso sobre as terras de sua área de estudo utilizando a equação universal de perdas de solo (EUPS). Já, no presente trabalho, foram avaliadas as áreas com maior potencial de degradação, correspondentes às utilizadas sistemática e inadequadamente com agricultura, que possui um efeito impactante maior sobre as terras (Koffler \& Moretti, 1991). 


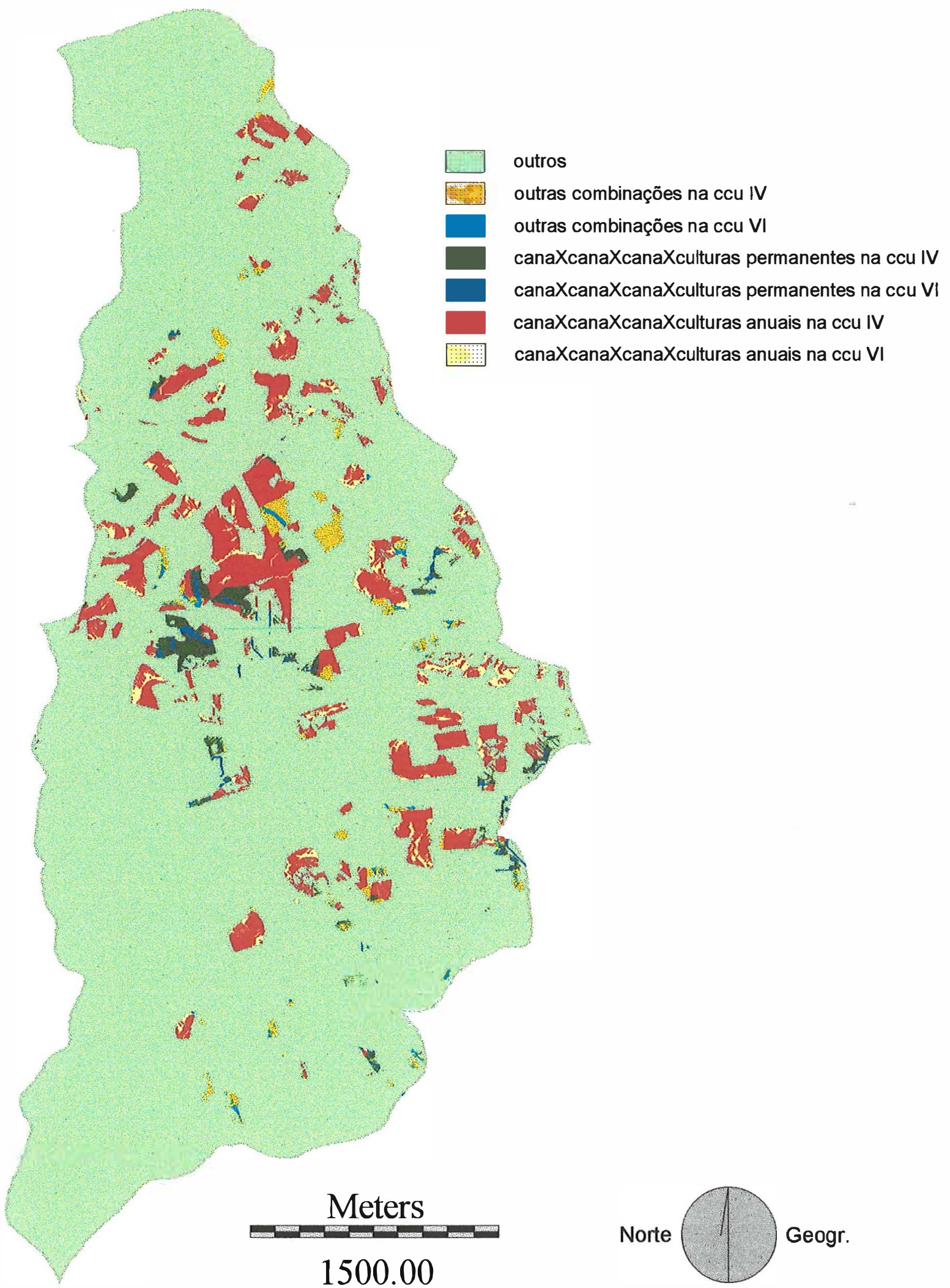

Figura 20. Uso sistemático com agricultura: 1995 a 1940. 
Tabela 21. Áreas das combinações de uso com classes de capacidade de uso nas terras sistematicamente agricultadas: 1995 a 1940.

\begin{tabular}{|c|c|c|c|}
\hline Combinações de uso da terra & Classes de capacidade de uso & Hectares & $\mathbf{\%}$ \\
\hline outras combinações & IV & 14,82 & 9,60 \\
\hline outras combinações & VI & 2,89 & 1,87 \\
\hline cana $x$ cana $x$ cana $x$ culturas permanentes & IV & 14,04 & 9,09 \\
\hline cana $x$ cana x cana $x$ culturas permanentes & VI & 4,80 & 3,11 \\
\hline cana x cana x cana x culturas anuais & IV & $\mathbf{9 3 , 8 1}$ & $\mathbf{6 0 , 7 5}$ \\
\hline cana x cana x cana $x$ culturas anuais & VI & 24,05 & 15,58 \\
\hline Total & & 154,41 & 100,00 \\
\hline
\end{tabular}

Por fim, cabe salientar mais uma vez que a extensão da categoria pasto, nas datas anteriores a 1995, evidencia as condições limitantes de uso das terras agricultadas em 1995 e, ainda, que a categoria reflorestamento destacou-se em 1962 muito provavelmente devido a incentivos fiscais.

\subsubsection{Usos anteriores das terras não agricultadas em 1995}

Os usos anteriores das terras não agricultadas em 1995, conforme as Figuras 21, 22, 23 e 24 e a Tabela 22, segue o padrão de ocupação de 1995, isto é, a predominância da categoria pasto e um total de área similar da categoria vegetação nativa. Ainda, vale destacar em 1978 e 1962 a extensão da categoria cana e das culturas anuais, em 1940.

A categoria pasto totalizou 86,20 ha de ocupação sistemática, nas quatro datas estudadas, concentrando-se em áreas marginais aos cursos d'água. Esse uso sistemático com pasto ocorreu, principalmente, sobre a combinação associação de solo litólico com solo podzólico e classe de declividade 0 a $2 \%$ (Tabela 23), o que comprovou a preferência de uso das margens dos cursos d'água com essa categoria. Além disso, essas terras estão enquadradas, particularmente, na classe de capacidade de uso IV, indicando sua vocação de uso. 


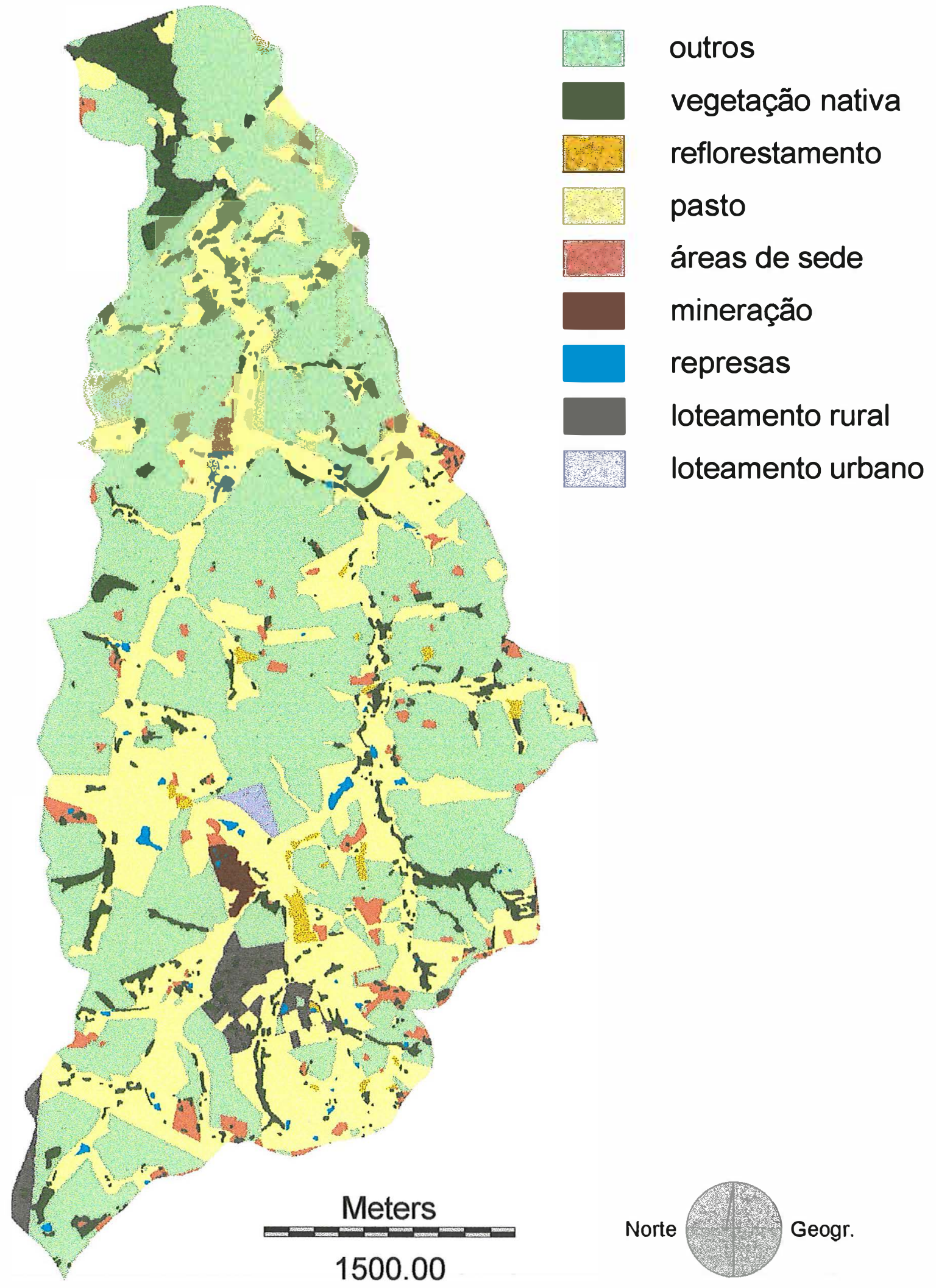

Figura 21. Uso das terras não agricultadas em 1995. 


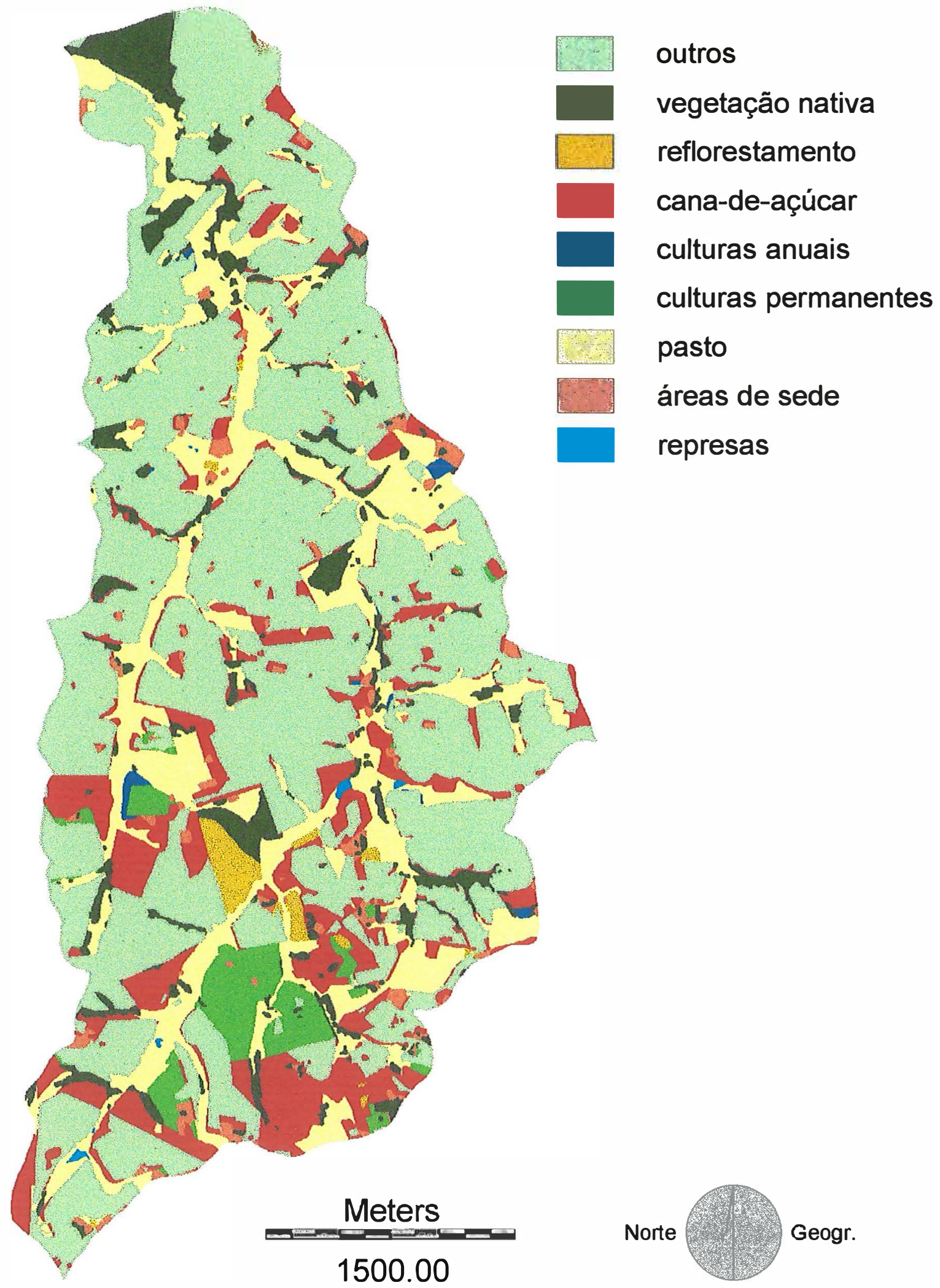

Figura 22. Uso em 1978 das terras não agricultadas em 1995. 


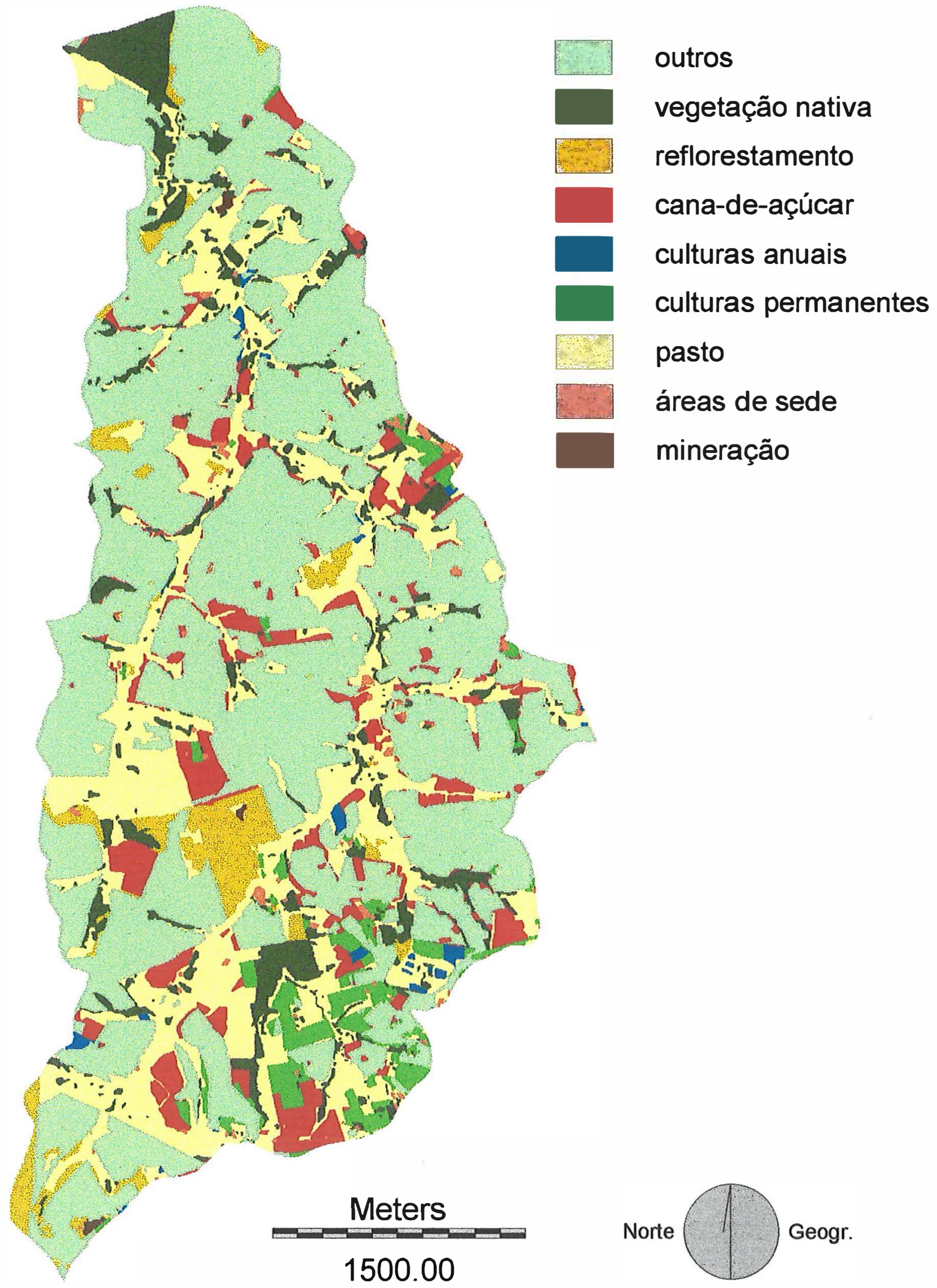

Figura 23. Uso em 1962 das terras não agricultadas em 1995. 


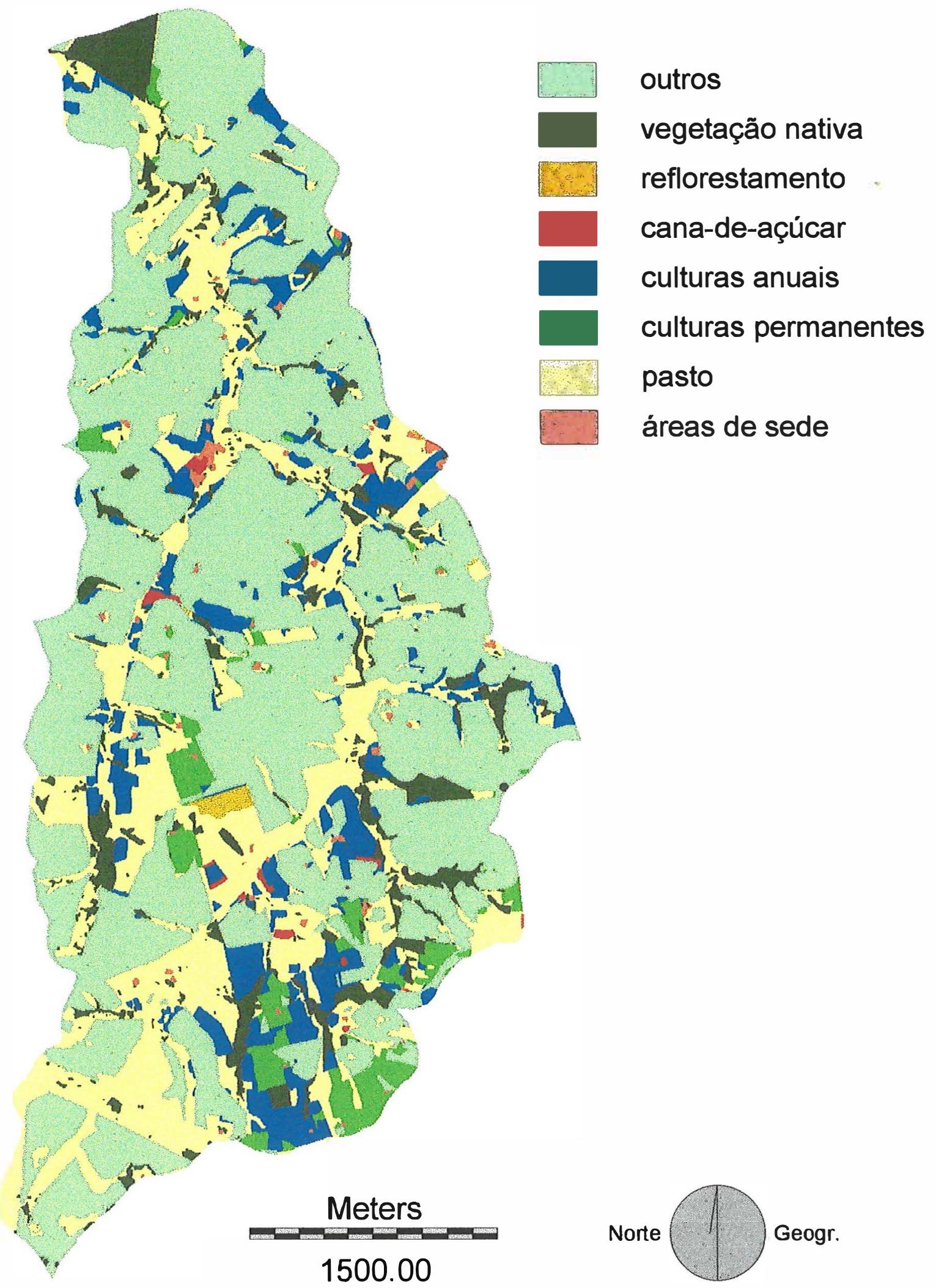

Figura 24. Uso em 1940 das terras não agricultadas em 1995. 
Tabela 22. Áreas das categorias de uso em 1995, 1978, 1962 e 1940 das terras não agricultadas em 1995.

\begin{tabular}{|c|c|c|c|c|c|c|c|c|}
\hline & \multicolumn{2}{|c|}{ Outros 95 x 1995 } & \multicolumn{2}{c|}{ Outros 95 x 1978 } & \multicolumn{2}{c|}{ Outros 95 x 1962 } & \multicolumn{2}{c|}{ Outros 95 x 1940 } \\
\cline { 2 - 10 } Categorias & Hectares & $\mathbf{\%}$ & Hectares & $\mathbf{\%}$ & Hectares & $\%$ & Hectares & $\%$ \\
\hline v.nat. & 121,28 & $\mathbf{1 8 , 8 4}$ & 107,38 & $\mathbf{1 6 , 6 8}$ & 113,10 & $\mathbf{1 7 , 5 7}$ & 104,33 & $\mathbf{1 6 , 2 0}$ \\
\hline reflor. & 11,55 & 1,79 & 17,74 & 2,76 & 58,98 & 9,16 & 4,47 & 0,69 \\
\hline cana & 0 & 0 & 178,34 & 27,70 & 99,29 & 15,42 & 5,10 & 0,79 \\
\hline c.an. & 0 & 0 & 4,65 & 0,72 & 7,31 & 1,14 & 129,80 & 20,16 \\
\hline c.prm. & 0 & 0 & 50,02 & 7,77 & 47,76 & 7,42 & 54,57 & 8,48 \\
\hline pasto & 427,48 & $\mathbf{6 6 , 3 9}$ & 256,14 & $\mathbf{3 9 , 7 8}$ & 305,02 & $\mathbf{4 7 , 3 7}$ & 336,09 & $\mathbf{5 2 , 2 0}$ \\
\hline á.sede & 40,75 & 6,33 & 27,97 & 4,34 & 10,64 & 1,65 & 9,51 & 1,48 \\
\hline l.rural & 23,89 & 3,71 & 0 & 0 & 0 & 0 & 0 & 0 \\
\hline l.urb. & 4,83 & 0,75 & 0 & 0 & 0 & 0 & 0 & 0 \\
\hline repres. & 7,88 & 1,22 & 1,63 & 0,25 & 0 & 0 & 0 & 0 \\
\hline miner. & 6,21 & 0,96 & 0 & 0 & 1,77 & 0,27 & 0 & 0 \\
\hline Total & 643,87 & 100,00 & 643,87 & 100,00 & 643,87 & 100,00 & 643,87 & 100,00 \\
\hline
\end{tabular}

Tabela 23. Áreas das combinações de unidades de solo com classes de declividade nas terras sistematicamente utilizadas com pasto: 1995 a 1940.

\begin{tabular}{|c|c|c|c|c|}
\hline $\begin{array}{c}\text { Unidades } \\
\text { de solo }\end{array}$ & $\begin{array}{c}\text { Classes de } \\
\text { declividade }\end{array}$ & ccu & Hectares & \% \\
\hline associação de solos podzólicos & $0-2 \%$ & III & 4,23 & $\%$ \\
\hline associação de solos podzólicos & $2-5 \%$ & III & 2,70 & 3,14 \\
\hline associação de solos podzólicos & $5-10 \%$ & III & 5,73 & 6,65 \\
\hline associação de solos podzólicos & $10-15 \%$ & IV & 6,98 & 8,10 \\
\hline associação de solos podzólicos & $>15 \%$ & VI & 8,53 & 9,89 \\
\hline associação de solo cambissolo com aluvial & $0-2 \%$ & II & 1,45 & 1,68 \\
\hline associação de solo cambissolo com aluvial & $2-5 \%$ & II & 0,44 & 0,51 \\
\hline associação de solo cambissolo com aluvial & $5-10 \%$ & III & 0,04 & 0,05 \\
\hline associação de solo cambissolo com aluvial & $10-15 \%$ & III & 0,02 & 0,02 \\
\hline associação de solo cambissolo com aluvial & $>15 \%$ & IV & 0,17 & 0,19 \\
\hline associação de solo litólico com podzólico & $\mathbf{0 - 2} \%$ & IV & $\mathbf{2 0 , 6 0}$ & $\mathbf{2 3 , 9 0}$ \\
\hline associação de solo litólico com podzólico & $2-5 \%$ & IV & 6,95 & 8,06 \\
\hline associação de solo litólico com podzólico & $5-10 \%$ & IV & 10,55 & 12,24 \\
\hline associação de solo litólico com podzólico & $10-15 \%$ & IV & 8,53 & 9,90 \\
\hline associação de solo litólico com podzólico & $>15 \%$ & VI & 9,29 & 10,78 \\
\hline Total & & & 86,20 & 100,00 \\
\hline
\end{tabular}


Quanto ao uso genérico em 1978, 1962 e 1940 das terras não agricultadas em 1995, é cabível afirmar que, ao contrário das terras agricultadas em 1995, ele foi adequado, como é possível observar na Tabela 24. Os grandes responsáveis por isso foram as categorias de uso pasto e vegetação nativa.

Tabela 24. Áreas de adequação de uso em 1995, 1978, 1962 e 1940 das terras não agricultadas em 1995.

\begin{tabular}{|c|c|c|c|c|c|c|c|c|c|}
\hline Categorias & adq. & \multicolumn{3}{|c|}{1995} & \multicolumn{2}{c|}{1978} & \multicolumn{2}{c|}{1962} & \multicolumn{2}{c|}{1940} \\
de uso & uso & Hectares & Hectares & $\%$ & Hectares & $\%$ & \multicolumn{2}{c|}{ Hectares } & $\%$ \\
\hline v.nat. & A & 121,28 & $\mathbf{1 8 , 8 4}$ & 107,38 & $\mathbf{1 6 , 6 8}$ & 113,10 & $\mathbf{1 7 , 5 7}$ & 104,33 & $\mathbf{1 6 , 2 0}$ \\
\hline reflor. & SB & 2,51 & 0,39 & 2,27 & 0,35 & 19,58 & 3,04 & 1,93 & 0,30 \\
\hline reflor. & A & 9,04 & 1,40 & 15,47 & 2,40 & 39,40 & 6,12 & 2,54 & 0,39 \\
\hline cana & A & 0 & 0 & 53,94 & 8,38 & 26,78 & 4,16 & 0,43 & 0,07 \\
\hline cana & R & 0 & 0 & 83,41 & 12,95 & 49,72 & 7,72 & 3,34 & 0,52 \\
\hline cana & SP & 0 & 0 & 40,99 & 6,37 & 22,79 & 3,54 & 1,33 & 0,21 \\
\hline c.an. & A & 0 & 0 & 0,79 & 0,12 & 2,22 & 0,34 & 24,65 & 3,83 \\
\hline c.an. & SP & 0 & 0 & 3,86 & 0,60 & 5,09 & 0,79 & 105,15 & 16,33 \\
\hline c.prm. & A & 0 & 0 & 13,92 & 2,16 & 17,58 & 2,73 & 26,34 & 4,09 \\
\hline c.prm. & SP & 0 & 0 & 36,10 & 5,61 & 30,18 & 4,69 & 28,23 & 4,38 \\
\hline pasto & SB & 97,78 & 15,19 & 47,79 & 7,42 & 60,49 & 9,39 & 80,72 & 12,54 \\
\hline pasto & A & 329,70 & $\mathbf{5 1 , 2 1}$ & 208,35 & $\mathbf{3 2 , 3 6}$ & 244,53 & $\mathbf{3 7 , 9 8}$ & 255,37 & $\mathbf{3 9 , 6 6}$ \\
\hline outros & - & 83,56 & 12,98 & 29,60 & 4,60 & 12,42 & 1,93 & 9,51 & 1,48 \\
\hline Total & & 643,87 & 100,00 & 643,87 & 100,00 & 643,87 & 100,00 & 643,87 & 100,00 \\
\hline
\end{tabular}

\subsubsection{Composição do quadro de uso das terras da microbacia em 1995}

\subsubsection{Composição das terras agricultadas em 1995}

Em geral, a composição do quadro das terras agricultadas em 1995 foi o resultado do crescimento galopante da cultura da cana-de-açúcar e da retração considerável das categorias pasto e culturas anuais (depois de 1940), combinado com a continuidade de áreas de cana já existentes, fenômenos evidenciados pela Tabela 19. 
Por outro lado, chama atenção o avanço da agricultura sobre as áreas de vegetação nativa, cujo destaque se deve a sua importância como categoria. Esses fatos tenderam a ocorrer também em todo o Município de Piracicaba (Ranieri \& Sparovek, 1993).

No que concerne à composicão do quadro de uso pela agricultura dos diferentes tipos de terra, a Tabela 25, obtida do cruzamento dos mapas de uso em 1995, 1978, 1962 e 1940 das terras agricultadas em 1995 com o mapa das combinações de unidades de solo e das classes de declividade, torna evidente a predominância de ocupação da agricultura, particularmente cana-de-açúcar, em 1995, nas associações de solos podzólicos e de solo litólico com solo podzólico (nas classes de declividade $5 \%$ a $10 \%$ e $10 \%$ a $15 \%$ ). Ainda, é possível perceber a predominância de ocupação das terras com classe IV de capacidade de uso. Por outro lado, as terras aptas para agricultura somam 232,42 ha.

Observa-se que essa distribuição configurou-se, principalmente, graças à permanência da cultura da cana-de-açúcar, seguida da expansão sobre a área ocupada por pasto em 1978 naquelas associações e classes de declividade referidas, com uma leve vantagem da associação de solo litólico com solo podzólico ( $22 \%$ maior), e na classe de capacidade de uso IV. As terras aptas à agricultura (232,42 ha) estavam ocupadas em 175,24 ha no ano de 1978.

O total da área de cana em 1978 deveu-se à manutenção das áreas de cana-de-açúcar já existentes em 1962, particularmente na associação de solo litólico com podzólico, e a incorporações de áreas que anteriormente eram ocupadas, principalmente, por pasto, seguida por reflorestamento nas mesmas terras já mencionadas no parágrafo anterior, com um leve predomínio da associação de solos podzólicos (aproximadamente $26 \%$ maior). As terras aptas à agricultura estavam ocupadas em 105,50 ha no ano de 1962. 
Tabela 25. Áreas de uso em 1995, 1978, 1962 e 1940 das combinações de unidades de solo com classes de declividade e classes de capacidade de uso das terras agricultadas em 1995.

\begin{tabular}{|c|c|c|c|c|c|c|c|c|c|c|c|}
\hline \multirow{2}{*}{$\begin{array}{l}\text { A } \\
\text { no } \\
\end{array}$} & \multirow{2}{*}{$\begin{array}{c}\text { Unidades } \\
\text { de solo }\end{array}$} & \multirow{2}{*}{$\begin{array}{l}\text { Classes } \\
\text { declivid. }\end{array}$} & \multirow[t]{2}{*}{$\mathrm{ccu}$} & \multicolumn{8}{|c|}{ Categorias de uso da terra ( ha ) } \\
\hline & & & & v.nat. & reflor. & cana & c.an. & c.prm. & pasto & á. sede & iner. \\
\hline & pdz.+pdz. & $0-2 \%$ & III & 0 & 0 & 52,62 & 0,79 & 0 & 0 & 0 & 0 \\
\hline & pdz.+pdz. & $2-5 \%$ & III & 0 & 0 & 32,39 & 1,59 & 0 & 0 & 0 & 0 \\
\hline & $\mid$ pdz.+pdz. & $5-10 \%$ & III & 0 & 0 & 114,40 & 4,46 & 0 & 0 & 0 & 0 \\
\hline \multirow[t]{2}{*}{1} & pdz.+pdz. & $10-15 \%$ & IV & 0 & 0 & 115,97 & 5,94 & 0 & 0 & 0 & 0 \\
\hline & pdz.+pdz. & $>15 \%$ & VI & 0 & 0 & 71,47 & 4,39 & 0 & 0 & 0 & 0 \\
\hline \multirow[t]{2}{*}{9} & cb. + al. & $0-2 \%$ & II & 0 & 0 & 13,39 & 0 & 0 & 0 & 0 & 0 \\
\hline & cb. + al. & $2-5 \%$ & II & 0 & 0 & 8,19 & 0 & 0 & 0 & 0 & 0 \\
\hline \multirow[t]{2}{*}{9} & cb. + al. & $5-10 \%$ & III & 0 & 0 & 3,82 & 0 & 0 & 0 & 0 & 0 \\
\hline & cb.+al. & $\mid 10-15 \%$ & III & 0 & 0 & 0,77 & 0 & 0 & 0 & 0 & 0 \\
\hline \multirow[t]{9}{*}{5} & cb. + al. & $>15 \%$ & IV & 0 & 0 & 1,15 & 0 & 0 & 0 & 0 & 0 \\
\hline & lit. $+\mathrm{pdz}$ & $0-2 \%$ & IV & 0 & 0 & 15,57 & 0,33 & 0 & 0 & 0 & 0 \\
\hline & lit. + pdz. & $2-5 \%$ & IV & 0 & 0 & 36,47 & 1,87 & 0 & 0 & 0 & 0 \\
\hline & lit.+pdz. & $5-10 \%$ & IV & 0 & 0 & 140,04 & 5,92 & 0 & 0 & 0 & 0 \\
\hline & lit.+pdz. & $10-15 \%$ & IV & 0 & 0 & 132,40 & 5,21 & 0 & 0 & 0 & 0 \\
\hline & lit. $+\mathrm{pdz}$ & $>15 \%$ & VI & 0 & 0 & 88,63 & 4,26 & 0 & 0 & 0 & 0 \\
\hline & pdz.+pdz. & $0-2 \%$ & III & 0,96 & 0,76 & 43,57 & 0,01 & 2,58 & 4,35 & 1,18 & 0 \\
\hline & pdz.+pdz. & $2-5 \%$ & III & 2,10 & 0,01 & 27,13 & 0,08 & 1,57 & 2,05 & 1,04 & 0 \\
\hline & pdz.+pdz. & $5-10 \%$ & III & 3,28 & 0,04 & $\mathbf{9 1 , 8 5}$ & 0,78 & 7,03 & 14,22 & 1,67 & 0 \\
\hline \multirow[t]{2}{*}{1} & pdz.+pdz. & $10-15 \%$ & IV & 5,89 & 0,13 & $\mathbf{8 8 , 9 7}$ & 0,49 & 6,42 & 19,03 & 0,98 & 0 \\
\hline & pdz.+pdz. & $>15 \%$ & VI & 5,21 & 0,47 & 49,83 & 0,05 & 5,23 & 14,66 & 0,41 & 0 \\
\hline \multirow[t]{2}{*}{9} & cb. + al. & $0-2 \%$ & II & 6,16 & 0,02 & 0,44 & 0 & 0 & 6,37 & 0,40 & 0 \\
\hline & cb. + al. & $2-5 \%$ & II & 3,98 & 0,80 & 0,10 & 0 & 0 & 3,27 & 0,04 & 0 \\
\hline \multirow[t]{2}{*}{7} & cb. + al. & $5-10 \%$ & III & 2,03 & 0,07 & 0,09 & 0 & 0 & 1,58 & 0,05 & 0 \\
\hline & cb. + al. & $\mid 10-15 \%$ & III & 0,29 & 0,01 & 0,01 & 0 & 0 & 0,46 & 0 & 0 \\
\hline \multirow[t]{6}{*}{8} & cb.+al. & $>15 \%$ & IV & 0,30 & 0 & 0,01 & 0 & 0 & 0,80 & 0,05 & 0 \\
\hline & lit.+pdz. & $0-2 \%$ & IV & 2,55 & 0,86 & 7,84 & 0,02 & 0,01 & 4,54 & 0,11 & 0 \\
\hline & lit.+pdz. & $2-5 \%$ & IV & 3,17 & 5,04 & 23,28 & 0,51 & 0,04 & 5,93 & 0,38 & 0 \\
\hline & lit.+pdz. & $5-10 \%$ & IV & 7,78 & 3,70 & 105,80 & 1,96 & 0,28 & 24,70 & 1,75 & 0 \\
\hline & lit.+pdz. & $10-15 \%$ & IV & 7,35 & 0,55 & 103,12 & 2,04 & 0,48 & 23,08 & 1,00 & 0 \\
\hline & lit. $+\mathrm{pdz}$ & $>15 \%$ & VI & 6,71 & 0,31 & 62,55 & 1,85 & 0,14 & 20,86 & 0,47 & 0 \\
\hline
\end{tabular}


Tabela 25. Continuação

\begin{tabular}{|c|c|c|c|c|c|c|c|c|c|c|c|}
\hline \multirow[t]{3}{*}{$\mathrm{A}$} & \multirow{2}{*}{\begin{tabular}{|c} 
Unidades \\
de solo
\end{tabular}} & \multirow{2}{*}{$\begin{array}{l}\text { Classes } \\
\text { declivid. }\end{array}$} & \multirow[t]{2}{*}{$\mathrm{ccu}$} & \multicolumn{8}{|c|}{ Categorias de uso da terra ( ha ) } \\
\hline & & & & v.nat. & reflor. & cana & c.an. & c.prm. & pasto & á.sede| & $\operatorname{miner}$ \\
\hline & pdz.+pdz. & $0-2 \%$ & III & 2,90 & 6,78 & 24,21 & 0,59 & 5,91 & 12,78 & 0,21 & 0,03 \\
\hline & pdz.+pdz. & $2-5 \%$ & III & 2,90 & 2,67 & 14,96 & 0,13 & 2,43 & 10,43 & 0,36 & 0,10 \\
\hline & pdz.+pdz. & $5-10 \%$ & III & 7,64 & 13,51 & 47,46 & 2,37 & 7,14 & 40,24 & 0,27 & 0,23 \\
\hline \multirow[t]{2}{*}{1} & pdz.+pdz. & $10-15 \%$ & IV & 11,77 & 16,98 & 45,46 & 1,65 & 6,26 & 39,65 & 0,14 & 0,01 \\
\hline & pdz.+pdz. & $>15 \%$ & VI & 11,04 & 8,66 & 23,90 & 0,46 & 3,78 & 27,84 & 0,18 & 0 \\
\hline \multirow[t]{2}{*}{9} & cb. + al. & $0-2 \%$ & II & 1,10 & 5,79 & 0,04 & 0 & 0 & 6,19 & 0,27 & 0 \\
\hline & cb. + al. & $2-5 \%$ & II & 0,76 & 5,60 & 0,12 & 0 & 0 & 1,68 & 0,04 & 0 \\
\hline \multirow[t]{2}{*}{6} & cb. + al. & $5-10 \%$ & III & 1,20 & 1,30 & 0,13 & 0 & 0 & 1,15 & 0,05 & 0 \\
\hline & cb. +al. & $10-15 \%$ & III & 0,31 & 0,17 & 0,01 & 0 & 0 & 0,29 & 0 & 0 \\
\hline \multirow[t]{9}{*}{2} & cb. + al. & $>15 \%$ & IV & 0,54 & 0,27 & 0,02 & 0 & 0 & 0,29 & 0,05 & 0 \\
\hline & lit. + pdz. & $0-2 \%$ & IV & 2,07 & 1,92 & 6,94 & 0,44 & 0,04 & 4,35 & 0,12 & 0,03 \\
\hline & lit.+pdz. & $2-5 \%$ & IV & 2,15 & 11,66 & 14,77 & 1,70 & 0,57 & 7,29 & 0,19 & 0,02 \\
\hline & \begin{tabular}{|l|} 
lit.+pdz. \\
\end{tabular} & $5-10 \%$ & IV & 9,05 & 15,53 & 72,45 & 5,90 & 3,71 & 38,57 & 0,74 & 0,01 \\
\hline & lit.+pdz. & $10-15 \%$ & IV & 10,64 & 7,89 & 72,45 & 2,10 & 2,09 & 41,69 & 0,59 & 0,17 \\
\hline & lit.+pdz. & $>15 \%$ & VI & 11,78 & 3,59 & 45,12 & 1,19 & 0,75 & 30,13 & 0,26 & 0,08 \\
\hline & pdz. + pdz. & $0-2 \%$ & III & 5,65 & 0,24 & 1,37 & 16,59 & 9,85 & 19,19 & 0,53 & 0 \\
\hline & pdz.+pdz. & $2-5 \%$ & III & 3,01 & 0,02 & 0,37 & 13,57 & 5,37 & 11,14 & 0,50 & 0 \\
\hline & pdz.+pdz. & $5-10 \%$ & III & 9,65 & 0,35 & 1,46 & 35,38 & 12,90 & 58,30 & 0,82 & 0 \\
\hline \multirow[t]{2}{*}{1} & pdz.+pdz. & $10-15 \%$ & IV & 11,31 & 0,25 & 0,87 & 33,16 & 8,63 & 66,91 & 0,78 & 0 \\
\hline & pdz. + pdz. & $>15 \%$ & VI & 10,47 & 0,20 & 0,57 & 18,80 & 5,40 & 40,18 & 0,25 & 0 \\
\hline \multirow[t]{2}{*}{9} & cb. + al. & $0-2 \%$ & II & 0,34 & 0 & 0,00 & 2,48 & 3,53 & 7,05 & 0 & 0 \\
\hline & cb. +al. & $2-5 \%$ & II & 0,22 & 0 & 0,32 & 0,37 & 2,88 & 4,36 & 0,05 & 0 \\
\hline \multirow[t]{2}{*}{4} & cb. +al. & $5-10 \%$ & III & 0,15 & 0 & 0,02 & 0,16 & 2,46 & 1,02 & 0,01 & 0 \\
\hline & cb.+al. & $10-15 \%$ & III & 0,01 & 0 & 0,03 & 0,03 & 0,24 & 0,46 & 0,01 & 0 \\
\hline \multirow[t]{6}{*}{0} & cb.+al. & $>15 \%$ & IV & 0,16 & 0 & 0,06 & 0,12 & 0,15 & 0,67 & 0,00 & 0 \\
\hline & lit.+pdz. & $0-2 \%$ & IV & 1,49 & 0 & 0,06 & 5,82 & 1,23 & 7,18 & 0,13 & 0 \\
\hline & lit.+pdz. & $2-5 \%$ & IV & 3,13 & 0,03 & 0,24 & 14,11 & 4,72 & 15,52 & 0,61 & 0 \\
\hline & lit.+pdz. & $5-10 \%$ & IV & 12,91 & 0,26 & 0,95 & 63,54 & 12,90 & 53,75 & 1,64 & 0 \\
\hline & lit.+pdz. & $10-15 \%$ & IV & 12,12 & 0,13 & 1,67 & 58,58 & 8,13 & $\mathbf{5 5 , 3 7}$ & 1,61 & 0 \\
\hline & lit.+pdz. & $>15 \%$ & VI & 12,05 & 0,11 & 1,16 & 33,95 & 3,66 & 41,26 & 0,71 & 0 \\
\hline
\end{tabular}

As áreas existentes em 1962 foram formadas, principalmente, pela expansão da cultura da cana-de-açúcar sobre áreas ocupadas antes com culturas anuais, que se tornaram praticamente inexpressivas, seguida da expansão sobre áreas de pasto. Essa expansão ocorreu, especialmente, sobre a associação de solo litólico com solo podzólico (35,66\% maior do que a associação de solos podzólicos) e classes de 
declividade $5 \%$ a $10 \%$ e $10 \%$ a $15 \%$, uma vez que as culturas anuais estavam localizadas majoritariamente nesses tipos de solos. Em bem menor grau, a categoria pasto cedeu áreas nessas duas associações e classes de declividade, particularmente na associação de solos podzólicos (44,28\% maior). As terras aptas à agricultura estavam ocupadas em 109,38 ha no ano de 1940 .

Cabe comentar que mudanças sobre a classe de declividade $>15 \%$ nas duas associações de solos (classe de capacidade de uso VI) também foram expressivas no período de tempo estudado. Além disso, a expansão da cultura da cana-de-açúcar sobre as terras com declividades até $5 \%$ foi mais intensa até 1978 . Por fim, as terras aptas para agricultura completaram sua ocupação somente em 1995.

\subsubsection{Composição das terras não agricultadas em 1995}

Conforme se observa na Tabela 22 , a composição das terras não agricultadas em 1995 constituiu-se de, principalmente, pasto e vegetação nativa. Pela Tabela 26, fica evidente que a categoria pasto se localizava, em 1995, nas duas associações principais de solos e nas classes de declividade $5 \%$ a $10 \%, 10 \%$ a $15 \%$ e $>15 \%$. As terras aptas à agricultura somam 166,74 ha. A categoria pasto totalizou essas áreas graças, especialmente, à manutenção e à expansão da categoria pasto e retração da cana-de-açúcar em relação a 1978. Fica claro, também, que os dois últimos processos se deram sobre as duas principais associações, particularmente na de solos podzólicos $(50 \%$ maior) e classe de declividade $10 \%$ a $15 \%$. Ademais, é significativa a diminuição da categoria vegetação nativa. Cabe, ainda, destacar o aparecimento das categorias loteamento rural e urbano, anteriormente inexistentes na microbacia hidrográfica do Ribeirão Pau d'Alhinho, e de uma área de mineração. Também ocorreu a ocupação completa por outras categorias das áreas de culturas permanentes, que deixaram de existir. As terras aptas à agricultura (166,74 ha) estavam ocupadas em 68,66 ha no ano de 1978. 
Tabela 26. Áreas de uso em 1995, 1978, 1962 e 1940 das combinações de unidades de solo com classes de declividade e classes de capacidade de uso das terras não agricultadas em 1995.

\begin{tabular}{|c|c|c|c|c|c|c|c|c|c|c|c|c|c|c|}
\hline \multirow[t]{2}{*}{ A } & \multirow{2}{*}{\begin{tabular}{|c} 
Unidades \\
de solo
\end{tabular}} & \multirow{2}{*}{$\begin{array}{r}\text { Classes } \\
\text { declivid. }\end{array}$} & \multirow{2}{*}{$\mathrm{ccu}$} & \multicolumn{11}{|c|}{ Categorias de uso da terra ( ha ) } \\
\hline & & & & v.nat. & reflor. & cana & c.an. & c.prm. & pasto & á.sede & $\operatorname{miner}$ & repres. & l.rural & l.urb. \\
\hline & pdz. + pdz. & $0-2 \%$ & III & 3,96 & 0,57 & 0 & 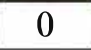 & 0 & 22,40 & 6,61 & 0 & 0,43 & 3,96 & 0,01 \\
\hline & pdz. + pdz. & $2-5 \%$ & III & 3,11 & 0,30 & 0 & 0 & 0 & 13,85 & 4,78 & 0 & 0,23 & 0,76 & 0,03 \\
\hline & pdz. + pdz. & $5-10 \%$ & III & 8,38 & 1,64 & 0 & 0 & 0 & 55,11 & 7,15 & 0 & 0,68 & 3,63 & 1,10 \\
\hline 1 & pdz. + pdz. & $10-15 \%$ & IV & 10,14 & 2,01 & 0 & 0 & 0 & 71,51 & 6,16 & 0,01 & 0,81 & 2,20 & 0,56 \\
\hline & pdz. + pdz. & $>15 \%$ & VI & 13,35 & 1,63 & 0 & 0 & 0 & 54,98 & 3,93 & 0 & 0,78 & 1,24 & 0,07 \\
\hline \multirow[t]{2}{*}{9} & cb. + al. & $0-2 \%$ & II & 13,90 & 0 & 0 & 0 & 0 & 3,97 & 0,71 & 0 & 0 & 0 & 0 \\
\hline & cb.+al. & $2-5 \%$ & II & 5,58 & 0 & 0 & 0 & 0 & 1,81 & 0,03 & 0 & 0 & 0 & 0 \\
\hline \multirow[t]{2}{*}{9} & cb.+al. & $5-10 \%$ & III & 0,94 & 0 & 0 & 0 & 0 & 0,35 & 0,02 & 0 & 0 & 0 & 0 \\
\hline & cb.+al. & $10-15 \%$ & III & 0,47 & 0 & 0 & 0 & 0 & 0,28 & 0,04 & 0 & 0 & 0 & 0 \\
\hline \multirow[t]{9}{*}{5} & cb. + al. & $>15 \%$ & IV & 0,90 & 0 & 0 & 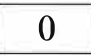 & 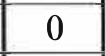 & 0,58 & 0,05 & 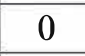 & 0 & 0 & 0 \\
\hline & lit. + pdz. & $0-2 \%$ & IV & 12,63 & 0,78 & 0 & 0 & 0 & 42,33 & 0,16 & 0,80 & 1,93 & 0,66 & 0,01 \\
\hline & lit. + pdz. & $2-5 \%$ & $|\mathrm{IV}|$ & 6,08 & 0,76 & 0 & 0 & 0 & 16,16 & 0,63 & 0,13 & 0,48 & 1,41 & 0,21 \\
\hline & lit.+ & $5-10 \%$ & IV & 10,70 & 1,73 & 0 & 0 & 0 & 48,37 & 4,03 & 3,83 & 0,84 & 3,24 & 1,68 \\
\hline & lit. $+p d z$ & $10-15 \%$ & IV & 12,90 & 1,16 & 0 & 0 & 0 & 50,16 & 3,76 & 0,88 & 1,01 & 4,14 & 0,82 \\
\hline & lit. + pdz. & $>15 \%$ & $\mathrm{VI}$ & 18,26 & 0,99 & 0 & 0 & 0 & 45,61 & 2,72 & 0,57 & 0,69 & 2,65 & 0,35 \\
\hline & pdz.+pdz. & $0-2 \%$ & III & 3,07 & 0,14 & \begin{tabular}{|l|}
15,89 \\
\end{tabular} & 0,35 & 1,53 & 11,72 & 5,02 & 0 & 0,23 & 0 & 0 \\
\hline & pdz. + pdz. & $2-5 \%$ & III & 3,77 & 0,16 & 7,33 & 0,01 & 1,36 & 7,61 & 2,81 & 0 & 0,03 & 0 & 0 \\
\hline & pdz.+pdz. & $5-10 \%$ & III & 7,03 & \begin{tabular}{|l|}
1,98 \\
\end{tabular} & 30,72 & 0,43 & 11,04 & 20,73 & 5,74 & 0 & 0,01 & 0 & 0 \\
\hline \multirow[t]{2}{*}{1} & pdz. + pdz. & $10-15 \%$ & IV & 7,84 & 2,36 & 41,13 & 2,15 & 9,12 & 28,03 & 2,70 & 0 & 0,07 & 0 & 0 \\
\hline & pdz. + pdz. & $>15 \%$ & VI & 10,20 & 1,16 & 27,07 & 0,81 & 5,44 & 29,73 & 1,39 & 0 & 0,19 & 0 & 0 \\
\hline \multirow[t]{2}{*}{9} & cb. + al. & $0-2 \%$ & II & 12,06 & 0 & 0 & 0 & 0 & 6,07 & 0,46 & 0 & 0 & 0 & 0 \\
\hline & cb.+al. & $2-5 \%$ & II & 6,39 & 0 & 0 & 0 & 0 & 1,02 & 0,02 & 0 & 0 & 0 & 0 \\
\hline \multirow[t]{2}{*}{7} & cb. + al. & $5-10 \%$ & III & 1,02 & 0 & 0 & 0 & 0 & 0,27 & 0,02 & 0 & 0 & 0 & 0 \\
\hline & cb.tal. & $10-15 \%$ & III & 0,37 & 0 & 0 & 0 & 0 & 0,38 & 0,04 & 0 & 0 & 0 & 0 \\
\hline \multirow[t]{6}{*}{8} & cb.tal. & $>15 \%$ & IV & 0,30 & 0 & 0 & 0 & 0 & 1,17 & 0,06 & 0 & 0 & 0 & 0 \\
\hline & lit.+pdz. & $0-2 \%$ & IV & 12,21 & 1,10 & 3,11 & 0,11 & 0,76 & 41,12 & 0,24 & 0 & 0,65 & 0 & 0 \\
\hline & lit. $+\mathrm{pdz}$ & $2-5 \%$ & IV & 5,53 & 0,51 & 2,31 & 0,02 & 1,69 & 14,59 & 1,04 & 0 & 0,16 & 0 & 0 \\
\hline & lit. $+\mathrm{pdz}$ & $5-10 \%$ & IV & 11,59 & 6,65 & 16,96 & 0,19 & 5,97 & 29,20 & 3,65 & 0 & 0,22 & 0 & 0 \\
\hline & lit. $+\mathrm{pdz}$ & $10-15 \%$ & IV & 12,37 & 2,66 & 19,91 & 0,28 & 8,37 & 28,11 & 3,08 & 0 & 0,05 & 0 & 0 \\
\hline & lit. $+p d z$ & $>15 \%$ & VI & 13,67 & 1,04 & 13,92 & 0,30 & 4,75 & 36,42 & 1,72 & 0 & 0,04 & 0 & 0 \\
\hline
\end{tabular}


Tabela 26. Continuação

\begin{tabular}{|c|c|c|c|c|c|c|c|c|c|c|c|c|c|c|}
\hline \multirow{2}{*}{\begin{tabular}{l|l}
$\mathrm{A}$ & $\mathrm{I}$ \\
$\mathrm{nd}$ &
\end{tabular}} & \multirow{2}{*}{$\begin{array}{c}\text { Unidades } \\
\text { de solo } \\
\end{array}$} & \multirow{2}{*}{$\begin{array}{r}\text { Classes } \\
\text { declivid. }\end{array}$} & \multirow{2}{*}{ ccu } & \multicolumn{11}{|c|}{ Categorias de uso da terra ( ha ) } \\
\hline & & & & v.nat. & reflor. & cana & c.an. & c.prm & pasto & á.sede & miner. & repres & l.rura & l.urb. \\
\hline & pdz. + pdz. & $0-2 \%$ & III & 3,79 & 6,18 & 7,11 & 1,08 & 5,13 & 13,05 & 1,53 & 0,07 & 0 & 0 & 0 \\
\hline & pdz. + pdz. & $2-5 \%$ & III & 3,45 & 1,71 & 4,66 & 0,13 & 3,74 & 8,37 & 0,79 & 0,22 & 0 & 0 & 0 \\
\hline & pdz. + pdz. & $5-10 \%$ & III & 7,41 & 10,56 & 14,91 & 1,02 & 8,71 & 32,74 & 1,95 & 0,37 & 0 & 0 & 0 \\
\hline 1 & pdz. + pdz. & $10-15 \%$ & IV & 10,37 & 9,10 & $|19,22|$ & 1,05 & $|11,59|$ & 40,93 & 1,11 & 0,02 & 0 & 0 & 0 \\
\hline & pdz. + pdz. & $>15 \%$ & $\mathrm{VI}$ & 12,30 & 3,97 & 12,40 & 1,08 & 6,76 & 38,82 & 0,66 & 0 & 0 & 0 & 0 \\
\hline \multirow[t]{2}{*}{9} & cb. + al. & $0-2 \%$ & II & 12,26 & 0,99 & 0 & 0 & 0 & 5,02 & 0,32 & 0 & 0 & 0 & 0 \\
\hline & cb. + al. & $2-5 \%$ & II & 6,32 & 0,14 & 0 & 0 & 0 & 0,94 & 0,02 & 0 & 0 & 0 & 0 \\
\hline \multirow[t]{2}{*}{6} & cb.+al. & $5-10 \%$ & III & 1,02 & 0 & 0,09 & 0 & 0 & 0,18 & 0,02 & 0 & 0 & 0 & 0 \\
\hline & cb. + al. & $10-15 \%$ & III & 0,54 & 0 & 0,01 & 0 & 0 & 0,20 & 0,04 & 0 & 0 & 0 & 0 \\
\hline \multirow[t]{9}{*}{2} & cb.tal. & $>15 \%$ & IV & 1,18 & 0,02 & 0 & 0 & 0 & 0,28 & 0,06 & 0 & U & 0 & 0 \\
\hline & lit. + pdz. & $0-2 \%$ & IV & 11,62 & 1,52 & 3,82 & 0,37 & 1,00 & 40,70 & 0,19 & 0,09 & 0 & 0 & 0 \\
\hline & lit. $+p d z$. & $2-5 \%$ & IV & 4,55 & 1,29 & 3,02 & 0,29 & 0,76 & 14,97 & 0,38 & 0,59 & 0 & 0 & 0 \\
\hline & lit. + pdz. & $5-10 \%$ & IV & 10,28 & 12,42 & 11,86 & 0,71 & 3,54 & 34,03 & 1,40 & 0,19 & 0 & 0 & 0 \\
\hline & lit. & $10-15 \%$ & IV & 11,83 & 7,73 & 11,80 & 1,05 & 4,50 & 36,41 & 1,35 & 0,16 & 0 & 0 & 0 \\
\hline & lit.+pdz. & $>15 \%$ & $\mathrm{VI}$ & 16,20 & 3,35 & 10,39 & 0,57 & 2,04 & 38,40 & 0,84 & 0,07 & 0 & 0 & 0 \\
\hline & pdz. + pdz. & $0-2 \%$ & III & 4,08 & 0,17 & 0,08 & 5,28 & 7,55 & 19,75 & 4 & $\overline{0}$ & 0 & 0 & 0 \\
\hline & pdz. + pdz. & $2-5 \%$ & III & 2,40 & 0,04 & 0,03 & 4,09 & 3,72 & 12,36 & 0,43 & 0 & 0 & 0 & 0 \\
\hline & pdz. + pdz. & $5-10 \%$ & III & 6,64 & 1,72 & 0,33 & 12,89 & 13,42 & 41,31 & 1,37 & 0 & 0 & 0 & 0 \\
\hline \multirow[t]{2}{*}{1} & pdz. + pdz. & $10-15 \%$ & IV & 9,96 & 0,80 & 0,38 & 17,74 & 12,79 & 50,90 & 0,83 & 0 & 0 & 0 & 0 \\
\hline & pdz. + pdz. & $>15 \%$ & VI & 11,18 & 0,23 & 0,43 & 14,96 & 7,49 & 41,30 & 0,40 & 0 & 0 & 0 & 0 \\
\hline \multirow[t]{2}{*}{9} & cb. + al. & $0-2 \%$ & II & 9,91 & 0 & 0 & 1,82 & 1,49 & 5,36 & 0 & 0 & 0 & 0 & 0 \\
\hline & cb.tal. & $2-5 \%$ & II & 5,83 & 0 & 0 & 0,34 & 0,13 & 1,12 & 0 & 0 & 0 & 0 & 0 \\
\hline \multirow[t]{2}{*}{4} & cb. + al. & $5-10 \%$ & III & 0,70 & 0 & 0 & 0,07 & 0,03 & 0,50 & 0 & 0 & 0 & 0 & 0 \\
\hline & cb.tal. & $10-15 \%$ & III & 0,30 & 0 & 0 & 0,17 & 0,01 & 0,32 & 0 & 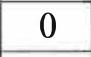 & 0 & 0 & 0 \\
\hline \multirow[t]{6}{*}{0} & cb. + al. & $>15 \%$ & IV & 0,41 & 0 & 0 & 0,09 & 0,01 & 1,02 & 0 & 0 & 0 & 0 & 0 \\
\hline & lit. +pdz. & $0-2 \%$ & IV & 11,00 & 0,01 & 0,92 & 6,64 & 0,56 & 39,80 & 0,38 & 0 & 0 & 0 & 0 \\
\hline & lit. + pdz. & $2-5 \%$ & IV & 3,87 & 0,15 & 0,20 & 4,29 & 0,44 & 15,98 & 0,92 & 0 & 0 & 0 & 0 \\
\hline & lit.+pdz. & $5-10 \%$ & IV & 8,93 & 0,76 & 0,91 & 20,69 & 2,73 & 38,59 & 1,82 & 0 & 0 & 0 & 0 \\
\hline & lit.+pdz. & $10-15 \%$ & IV & 9,89 & 0,41 & 0,94 & 23,28 & 2,71 & 36,10 & 1,50 & 0 & 0 & 0 & 0 \\
\hline & lit. + pdz. & $>15 \%$ & VI & 19,24 & 0,19 & 0,90 & 17,47 & 1,51 & 31,70 & 0,83 & 0 & 0 & 0 & 0 \\
\hline
\end{tabular}

As terras ocupadas em 1978 eram em 1962 utilizadas em maior extensão com pasto, seguida de cana, nas duas associações principais de solos (pendendo mais para associação de solos podzólicos e classe de declividade $10 \%$ a $15 \%$ ) e vegetação nativa, sem predominância expressiva de solo e declividade. Vale destacar, ainda, que havia uma área significativa maior de reflorestamento (nas duas associações e, especialmente, na classe de declividade $5 \%$ a $10 \%$ ) e culturas permanentes (também na 
associação de solos podzólicos na classe de declividade $10 \%$ a $15 \%$ ). Mais uma vez, houve um descréscimo da área de vegetação nativa. Assim, o quadro de 1978 formou-se, particularmente, graças à manutenção das áreas cobertas por pasto e expansão da cultura canavieira sobre áreas de pasto (mais uma vez em especial sobre a associação de solos podzólicos e classe de declividade $10 \%$ a $15 \%$ ) e reflorestamento. As terras aptas à agricultura estavam ocupadas em 46,59 ha no ano de 1962.

Por sua vez, seguindo uma abordagem retrospectiva, as terras de 1962, eram ocupadas anteriormente com pasto, que configurava a maior categoria entre todas, nas duas principais associações de solos, em especial na de solos podzólicos e classe de declividade $10 \%$ a $15 \%$. Ainda, a categoria culturas anuais ocupava uma área expressiva da microbacia nas duas principais associações, em particular, na de solo litólico com solo podzólico (25\% maior). Portanto, as terras de 1962 configuraram-se pela manutenção da categoria pasto, manutenção da categoria vegetação nativa, expansão da cultura canavieira (nas duas principais associações, particularmente na de solos podzólicos, classe de declividade $10 \%$ a $15 \%$ ) sobre a categoria culturas anuais, seguida de pasto e expansão da categoria reflorestamento sobre a categoria culturas anuais. As terras aptas à agricultura estavam ocupadas em 51,45 ha no ano de 1940.

Finalmente, cabe destacar que uma parte expressiva e até mesmo integral das terras aptas para agricultura tendeu a ser subutilizada ou utilizada sem agricultura. Esse fato demonstrou a falta de planejamento e negligência para com terras que poderiam substituir outras que foram superutilizadas ou utilizadas com risco.

\subsubsection{Dinâmica temporal de ocupação da categoria vegetação nativa}

A categoria vegetação nativa ocupava, em 1995, uma área menor em relação às outras datas, o que fica evidenciado pela Tabela 17 (em discordância com os dados para todo o Município de Piracicaba (Ranieri \& Sparovek, 1993)). Somando os dados dessa categoria nas Tabelas 25 e 26 , notou-se que ela se distribuía entre as duas 
associações principais de solos e as classes de declividade $5 \%$ a $10 \%, 10 \%$ a $15 \%$ e, especialmente $>15 \%$ (aproximadamente $33 \%$ maior). Sua composição, portanto, deveuse mais a perdas do que ganhos, principalmente para agricultura, visível na Tabela 19.

Em todo o município, a composição dessa categoria foi semelhante à encontrada na microbacia do Ribeirão Pau d'Alhinho (Ranieri \& Sparovek, 1993). Todavia, chama mais atenção o fato da vegetação nativa ter ocupado uma área bem limitada já em 1940, o que se manteve relativamente constante em todo período abordado. Ainda, pelas Tabelas 19 e 21, é possível perceber que a categoria vegetação nativa extingüiu-se de um lado e elevou-se, em menor proporção, de outro, o que mostra uma dinâmica considerável, especialmente, junto aos cursos d'água, comprovada pela Figura 25.

De forma geral, a vegetação nativa ocupou mais terras das duas principais associações, quando os valores das Tabelas 25 e 26 são somados, em particular a de solo litólico com solo podzólico. Ainda, é possível afirmar que a partir de 1962 a diferença entre as duas principais associações de solo aumentou e que as áreas com declividades acima de 10\% diminuíram com maior intensidade a partir de 1962 e as abaixo de $10 \%$ a partir de 1978.

\subsubsection{Ocupação das áreas de preservação permanente}

Nota-se, pelas Figuras 26, 27, 28 e 29 e pela Tabela 27 que a vegetação nativa não é a categoria mais expressiva nas áreas de preservação permanente, no período estudado, cabendo ao pasto esse papel. A vegetação nativa sofreu um pequeno decréscimo no período estudado (juntamente com a categoria pasto), acompanhando seu declínio em área total. Em contrapartida, a categoria cana-de-açúcar expandiu-se. Porém, comparando-se os valores em hectares das Tabelas 17 e 27, apreende-se que o montante da categoria vegetação nativa, nas áreas de presevação permanente, em relação à sua área total, foi maior em 1995 do que nas outras datas $(42,55 \%, 33,39 \%, 36,38 \%, 33,59 \%)$. 


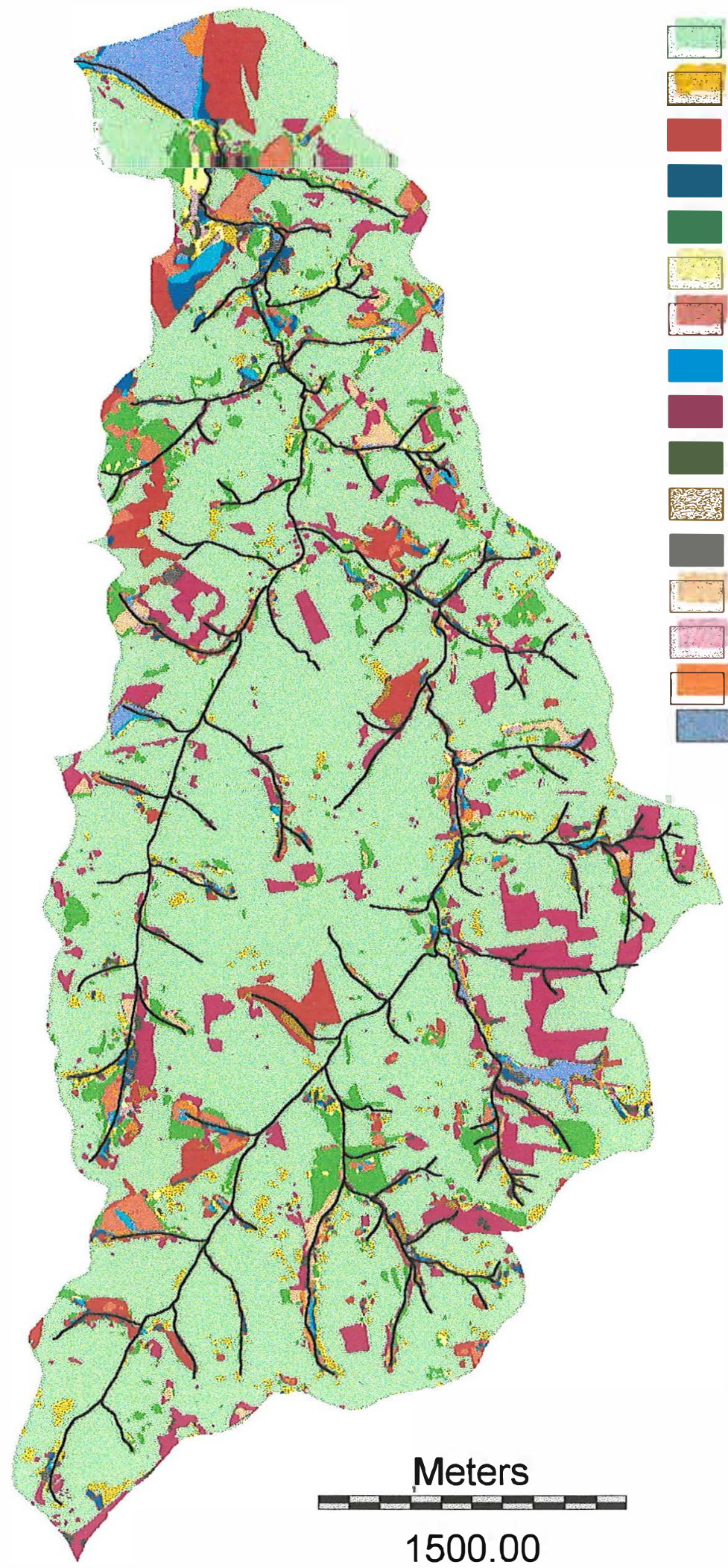

outros

v.nat. $x$ outros $x$ outros $x$ outros outros $x$ v.nat. $x$ outros $x$ outros v.nat. $x$ v.nat. $x$ outros $x$ outros outros $x$ outros $x$ v.nat $x$ outros v.nat. $x$ outros $x$ v.nat. $x$ outros outros $x$ v.nat. $x$ v.nat. $x$ outros v.nat. $x$ v.nat. $x$ v.nat. $x$ outros outros $x$ outros $x$ outros $x$ v.nat. v.nat. $x$ outros $x$ outros $x$ v.nat. outros $x$ v.nat. $x$ outros $x$ v.nat. v.nat. $x$ v.nat. $x$ outros $x$ v.nat. outros $x$ outros $\times$ v.nat. $x$ v.nat. v.nat. $x$ outros $x$ v.nat. $x$ v.nat. outros $\times$ v.nat. $x$ v.nat. $x$ v.nat. v.nat. $x$ v.nat. $\times$ v.nat. $\times$ v.nat.

Figura 25. Dinâmica ten poral de distribuição da categonia vegetação nativa (1995 x 1978 x 1962 x 1940). 


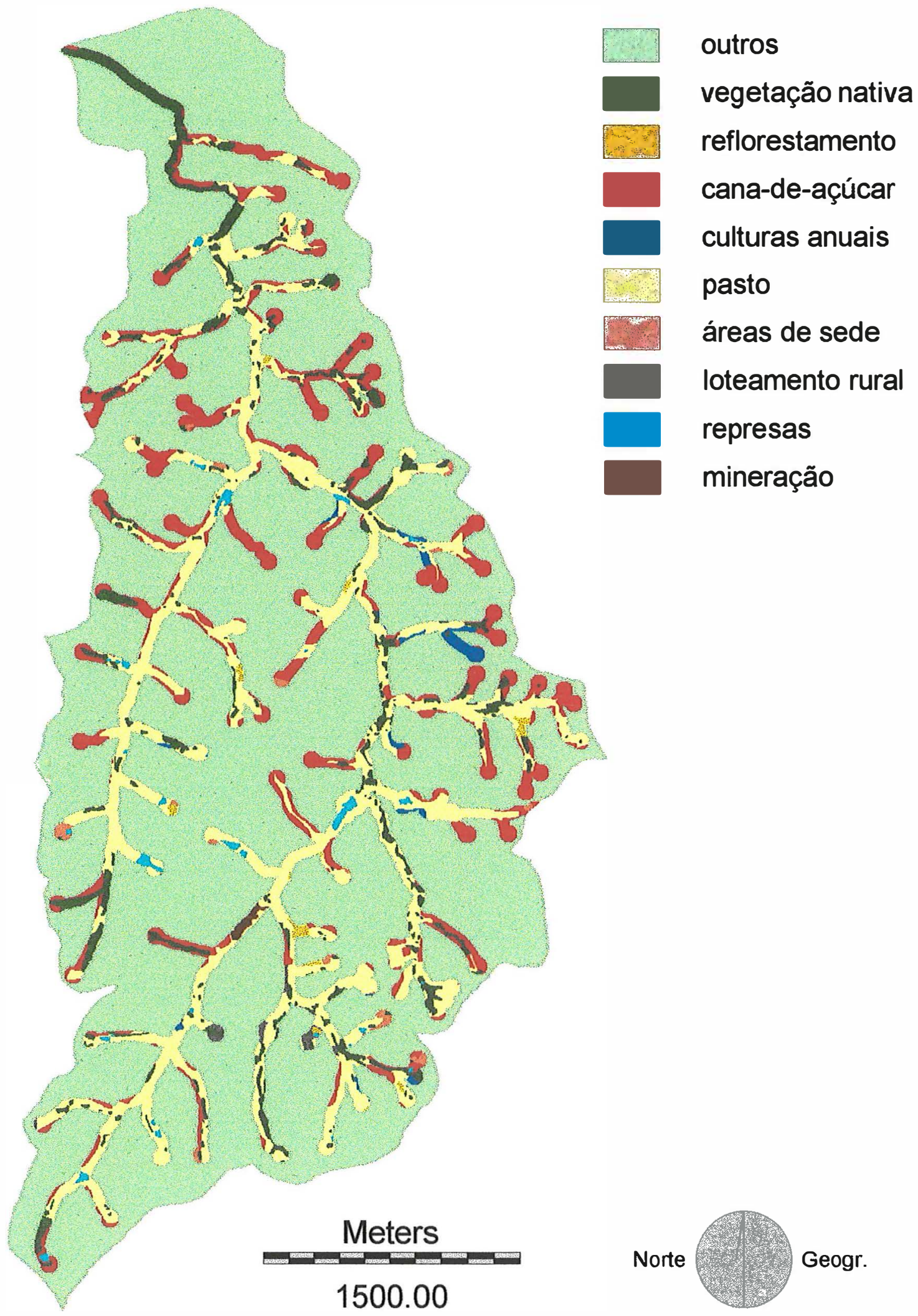

Figura 26. Uso em 1995 das terras em áreas de preservação permanente. 


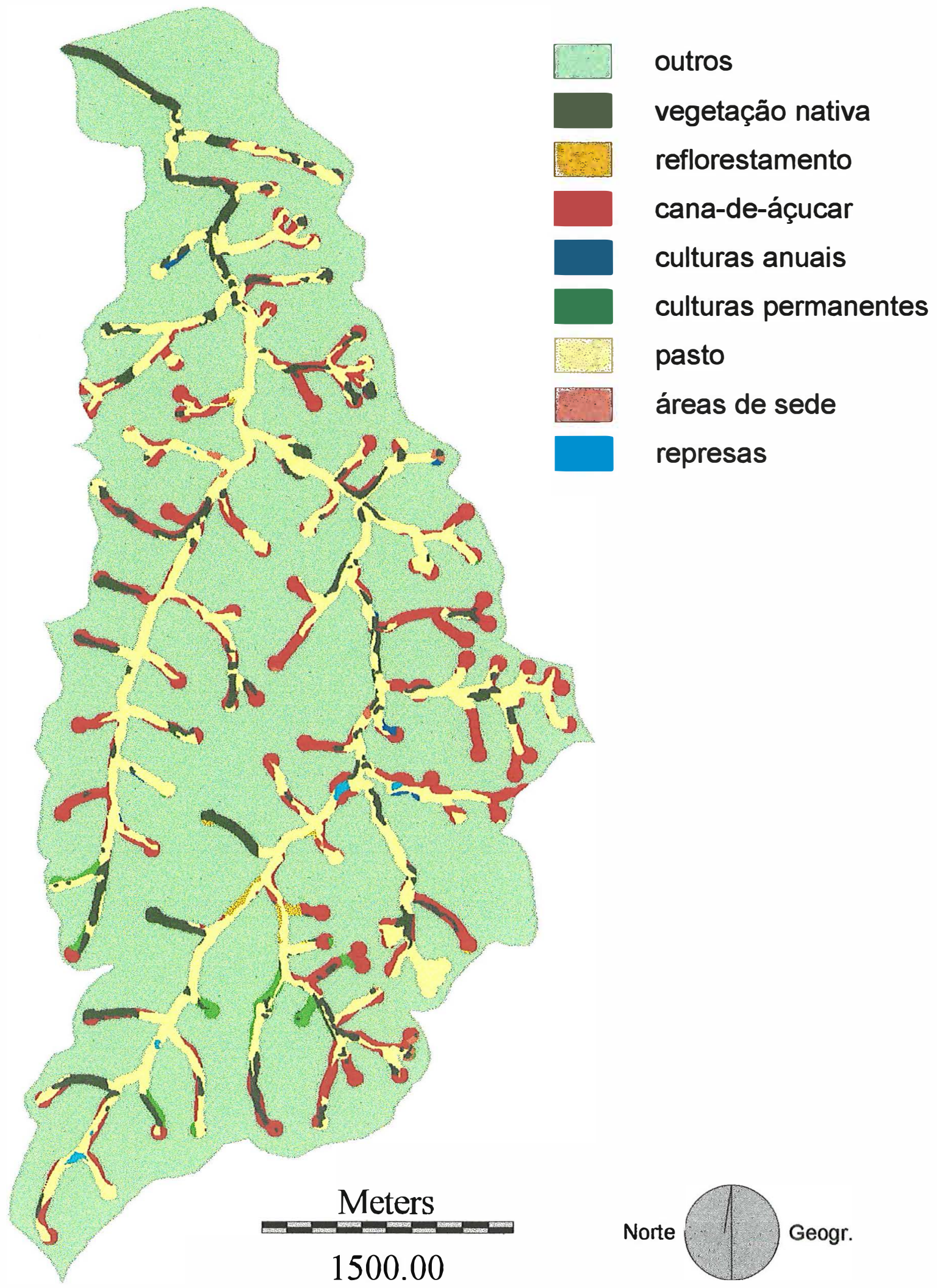

Figura 27. Uso em 1978 das terras em áreas de preservação permanente. 


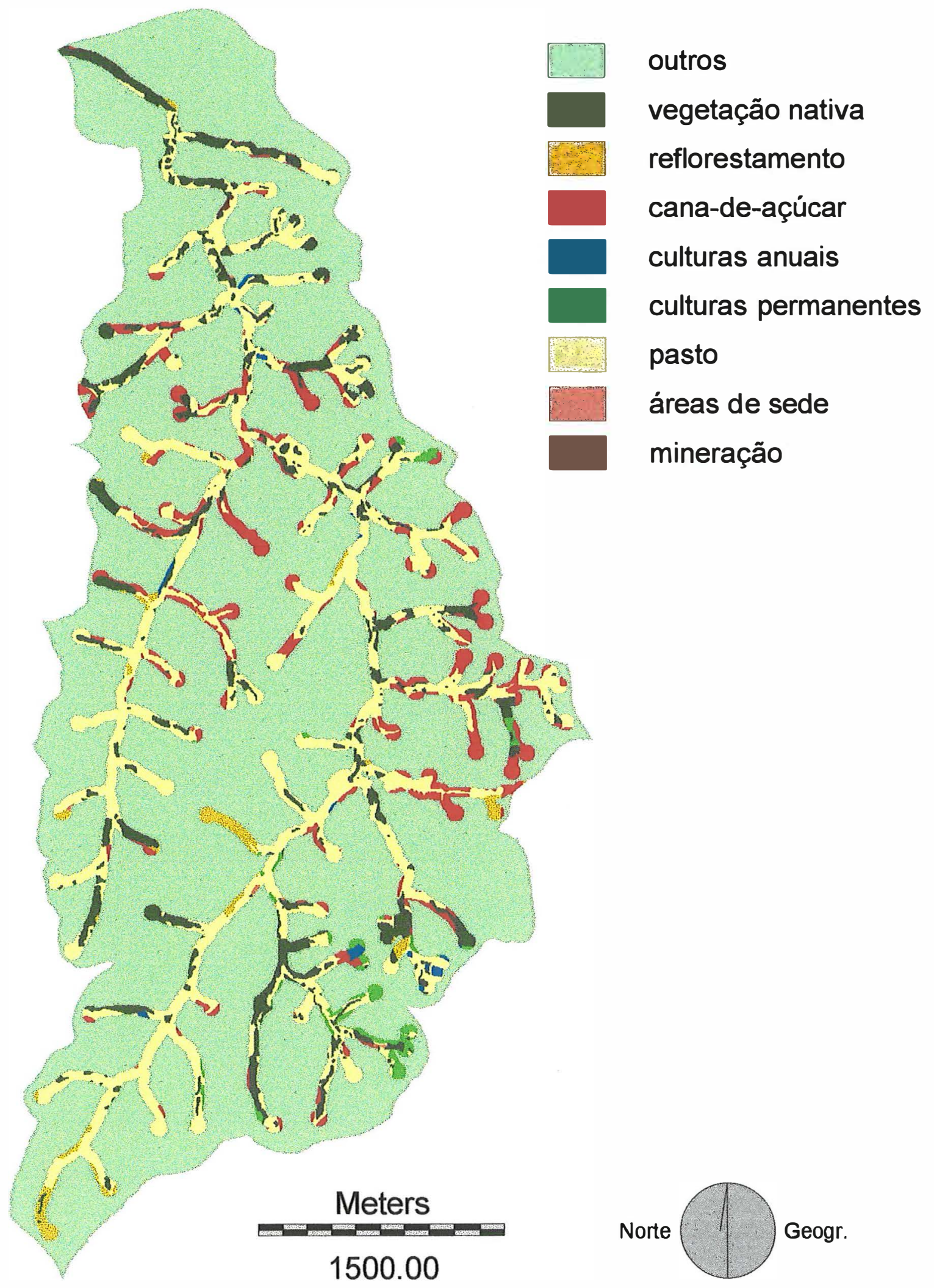

Figura 28. Uso em 1962 das terras em áreas de preservação permanente. 


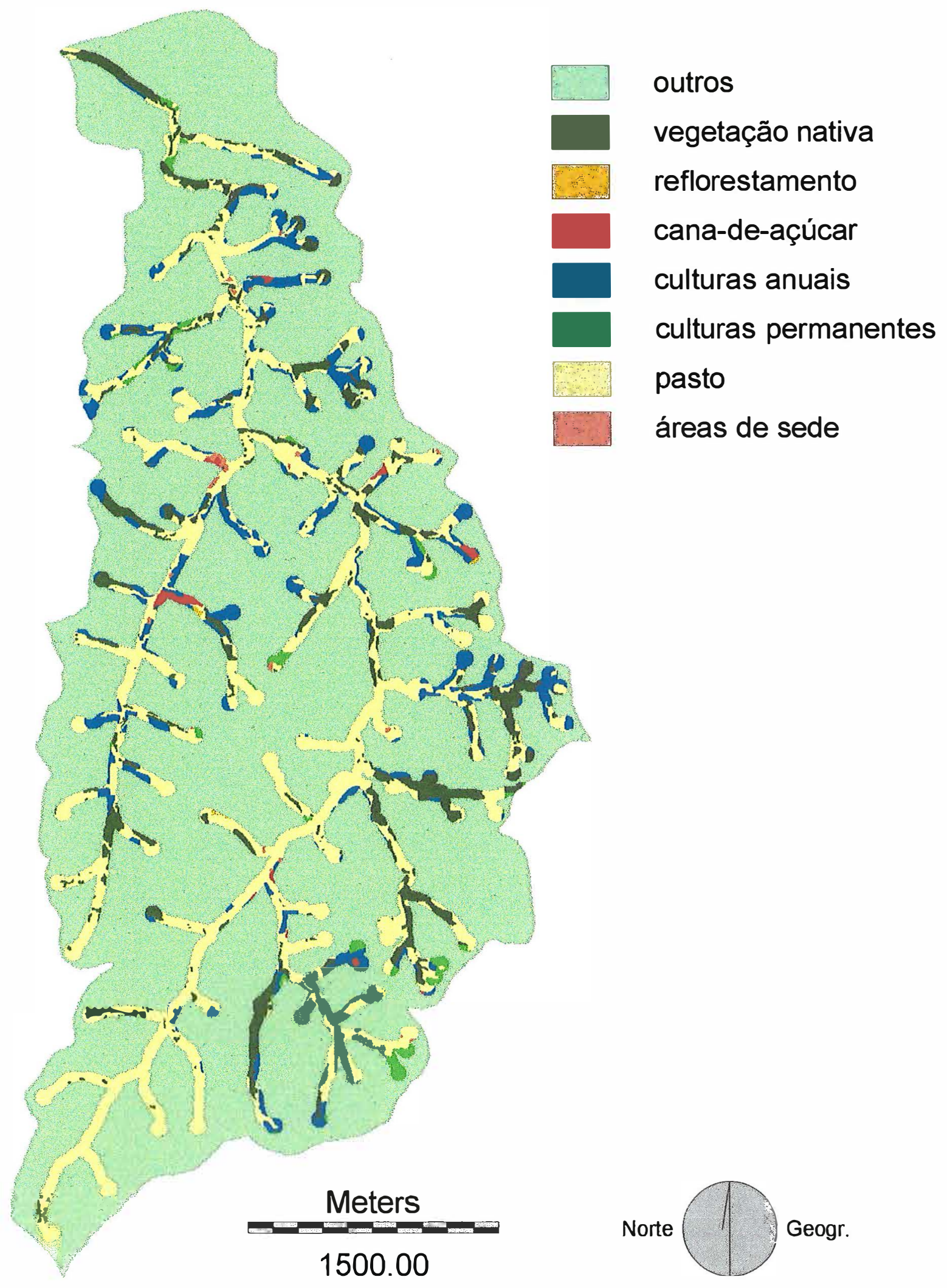

Figura 29. Uso em 1940 das terras em áreas de preservação permanente. 
Tabela 27. Áreas das categorias de uso em 1995, 1978, 1962 e 1940 das terras em áreas de preservação permanente.

\begin{tabular}{|c|c|c|c|c|c|c|c|c|c|}
\hline $\begin{array}{c}\text { Categorias de } \\
\text { uso da terr. pr.pm. }\end{array}$ & Hectares 1995 & \multicolumn{1}{|c|}{ Árs.pr.pm. x 1978 } & \multicolumn{1}{|c|}{ Árs.pr.pm. x 1962 } & \multicolumn{1}{|c|}{ Ár.pr.pm. x 1940 } \\
\hline v.nat. & 53,92 & 16,29 & 58,53 & 17,69 & 73,39 & 22,18 & 67,99 & 20,55 \\
\hline reflor. & 2,96 & 0,89 & 2,45 & 0,74 & 11,21 & 3,39 & 0,47 & 0,14 \\
\hline cana & 91,72 & 27,72 & 90,73 & 27,42 & 50,73 & 15,33 & 3,08 & 0,93 \\
\hline c.an. & 4,71 & 1,42 & 1,33 & 0,40 & 2,51 & 0,76 & 59,23 & 17,90 \\
\hline c.prm. & 0 & 0 & 6,69 & 2,02 & 8,86 & 2,68 & 10,00 & 3,02 \\
\hline pasto & 164,59 & $\mathbf{4 9 , 7 4}$ & 167,19 & $\mathbf{5 0 , 5 3}$ & 183,02 & $\mathbf{5 5 , 3 1}$ & 188,27 & $\mathbf{5 6 , 9 0}$ \\
\hline á.sede & 4,05 & 1,22 & 2,34 & 0,71 & 0,81 & 0,24 & 1,83 & 0,55 \\
\hline l.rural & 1,89 & 0,57 & 0 & 0 & 0 & 0 & 0 & 0 \\
\hline repres. & 5,79 & 1,75 & 1,62 & 0,49 & 0 & 0 & 0 & 0 \\
\hline miner. & 1,25 & 0,38 & 0 & 0 & 0,34 & 0,10 & 0 & 0 \\
\hline Total & 330,87 & 100,00 & 330,87 & 100,00 & 330,87 & 100,00 & 330,87 & 100,00 \\
\hline
\end{tabular}

Isso poderia indicar um respeito maior por parte dos proprietários rurais ao Código Florestal e/ou uma ação efetiva da fiscalização. Entretanto, pelos dados de área plantada e de pasto, verifica-se que isso não é totalmente verdadeiro.

Quanto ao uso das cabeceiras (Tabela 28), é possivel verificar uma certa vantagem da categoria pasto nos anos de 1962 e 1940, em relação às categorias agrícolas. Já em 1995 e 1978, esse quadro inverteu-se, predominando as culturas agrícolas, particularmente cana-de-açúcar. Assim, é possível afirmar que, em geral, as cabeceiras da rede de drenagem eram mais protegidas em 1962 e 1940 do que no outro par de anos. Isso já havia sido observado por Angulo Filho (1981) para solos com B latossólico da região canavieira de Piracicaba. 
Tabela 28. Áreas das categorias de uso em 1995, 1978, 1962 e 1940 das cabeceiras de drenagem da microbacia.

\begin{tabular}{|c|c|c|c|c|c|c|c|c|c|}
\hline $\begin{array}{c}\text { Categorias de } \\
\text { uso da terra }\end{array}$ & Cabeceiras x 1995 & \multicolumn{3}{|c|}{ Cabeceiras x 1978 } & \multicolumn{3}{|c|}{ Cabeceiras x 1962 } & \multicolumn{3}{|c|}{ Cabeceiras x 1940 } \\
\hline v.nat. & 6,51 & 9,04 & 7,78 & 10,80 & 11,57 & 16,07 & 11,11 & 15,43 \\
\hline reflor. & 0,57 & 0,78 & 0,25 & 0,35 & 3,58 & 4,97 & 0,22 & 0,31 \\
\hline cana & 37,42 & $\mathbf{5 1 , 9 7}$ & 37,47 & $\mathbf{5 2 , 0 4}$ & 20,06 & $\mathbf{2 7 , 8 6}$ & 0,56 & 0,78 \\
\hline c.an. & 1,14 & 1,58 & 0,37 & 0,51 & 1,01 & 1,40 & 18,62 & $\mathbf{2 5 , 8 5}$ \\
\hline c.prm. & 0 & 0 & 2,42 & 3,36 & 4,36 & 6,06 & 5,45 & 7,56 \\
\hline pasto & 21,53 & $\mathbf{2 9 , 9 0}$ & 22,46 & $\mathbf{3 1 , 2 0}$ & 31,24 & $\mathbf{4 3 , 3 9}$ & 35,73 & $\mathbf{4 9 , 6 2}$ \\
\hline á.sede & 3,29 & 4,57 & 1,25 & 1,74 & 0,19 & 0,26 & 0,33 & 0,45 \\
\hline l.rural & 0,97 & 1,35 & 0 & 0 & 0 & 0 & 0 & 0 \\
\hline repres. & 0,58 & 0,81 & 0 & 0 & 0 & 0 & 0 & 0 \\
\hline Total & 72,00 & 100,00 & $\mathbf{7 2 , 0 0}$ & 100,00 & 72,00 & 100,00 & 72,00 & 100,00 \\
\hline
\end{tabular}




\section{CONCLUSÕES}

- A fotointerpretação, em geral, alcançou resultados satisfatórios. Seu grau de dificuldade aumentou proporcionalmente ao distanciamento temporal das fotografias aéreas, apresentando uma diferença significativa entre 1995, 1978 e 1962 e as de 1940.

- As geometrias de pontos de controle selecionadas para digitalização dos decalques de uso da terra apresentaram, em todos os casos, graus de erro abaixo do limite aceitável. Entretanto, a correção dos erros após a união dos arquivos vetoriais digitalizados separadamente exigiu trabalho exaustivo. A digitalização dos decalques de uso da terra foi prejudicada pela escala com que foram digitalizados. $O$ tamanho de pixel de $5 \mathrm{~m}$ foi o que apresentou os melhores resultados combinados dos fatores representação das feições digitalizadas, tempo de processamento e tamanho de arquivo.

- Apesar da microbacia hidrográfica do Ribeirão Pau d'Alhinho apresentar predomínio de terras com baixa aptidão para cultivo intensivo, a cultura da cana-de-açúcar era a categoria predominante em 1995, o que faz denotar uma porcentagem expressiva de terras com uso inadequado. Além disso, essa cultura já ocupava uma área considerável em 1962 com uso inadequado, o mesmo ocorrendo em 1940. Durante o período estudado, constatou-se que $10,25 \%$ das terras da microbacia foram sistematicamente utilizadas de forma inadequada. A ocupação das terras da microbacia discerniu da predominante no Município de Piracicaba, pois apesar de possuir terras aptas para agricultura disponíveis tendeu a aproveitar as inadequadas. No que concerne à 
categoria vegetação nativa, o estudo constatou que ela ocupava aproximadamente $8 \%$ da microbacia em 1995. Já as áreas de preservação permanente estavam, em todo o período estudado, predominantemente cobertas por pasto. A despeito do que se poderia esperar, a vegetação nativa já em 1940 não era expressiva (12\% da microbacia) e nem sequer às margens dos cursos d'água e suas cabeceiras.

- A metodologia de análise temporal do uso da terra por meio de técnicas de geoprocessamento mostrou-se adequada e o tipo de análise abordada nesse trabalho revelou-se vantajosa, uma vez que possibilitou investigar o histórico de ocupação das terras, tomando especialmente como referência o uso mais recente. 


\section{REFERÊNCIAS BIBLIOGRÁFICAS}

ADENIYI, P.O. Land use change analysis using sequential aerial photography and computer techniques. Photogrammetric Engineering and Remote Sensing, v.46, n.11, p.1447-64, nov. 1980.

ANDERSON, P.S. (Ed.-Coord.) Fundamentos para fotointerpretação. Rio de Janeiro: Sociedade Brasileira de Cartografia, 1982. 136p.

ANGULO FILHO, R. Variações de características de redes de drenagem em função das fotografias aéreas verticais obtidas em épocas diferentes. Piracicaba, 1981. 128p. Dissertação (Mestrado) - Escola Superior de Agricultura "Luiz de Queiroz", Universidade de São Paulo.

ARONOFF, S. Geographical information systems: a management perspective. Ottawa: WDL Publications, 1995. 294p.

AUDI, R. Estudo da cultura canavieira na região de Piracicaba por fotointerpretação. Bragantia, v.24, n.18, p.201-218, abr. 1965.

BAKER, R.D.; deSTEIGUER, J.E.; GRANT, D.E.; NEWTON, M.J. LandUse/Land-Cover Mapping from Aerial Photographs. Photogrammetric Engineering and Remote Sensing, vol.45, n.5, p.661-668, may 1979. 
BARROS, Z.X.; CARDOSO, L.G. Estudo fotointerpretativo das áreas de cana-deaçúcar, café e eucalipto em Botucatu, SP. Científica, v.20, n.1, p.165-171, 1992.

BARROS, Z.X.; CARDOSO, L.G.; TARGA, L.A. Utilização de fotografias aéreas em ocupação do solo por cobertura vegetal. In: CONGRESSO BRASILEIRO DE ENGENHARIA AGRÍCOLA (CONBEA), XVI, Jundiaí, 1987. Anais. Jundiaí: SBEA/IAC/Secretaria de Agricultura do Estado de São Paulo. p.598-603.

BERTOLAMI, M.A. Impactos acumulativos e análise geográfica temporal no planejamento do uso da terra. Caso de estudo: bacia do Ribeirão Claro (SP). Rio Claro, 1997. 106p. Dissertação (Mestrado) - Instituto de Geociências e Ciências Exatas, Universidade Estadual Paulista.

BORGES, M.H.; PFEIFER, R.M.; DEMATTÊ, J.A.M. Evolução e mapeamento do uso da terra, através de imagens aerofotogramétricas e orbitais em Santa Bárbara d'Oeste (S.P.) Scientia Agricola, v.50, n.3, p.365-371, out/dez. 1993.

BOLSTAD, P.V. Geometric errors in natural resource GIS data: tilt and terrain effects in aerial photographs. Forest Science, vol.38, n.2, p.367-380, apr. 1992.

BRACKEN, I.; WEBSTER, C. Information technology in geography and planning: including principles of GIS. London: Routledge, 1992. 444p.

BURROUGH, P.A. Principles of geographical information systems for land resources assesment. Oxford: Clarendon Press, 1986. 193p.

CAMPOS, S.; AUGUSTO, M.R.; SILVA, A.P.; BARROS, Z.X.; CARDOSO, L.G. Caracterização da ocupação do solo na bacia do Rio Lavapés, Botucatu (SP) de 1962 a 1972. In: CONGRESSO BRASILEIRO DE ENGENHARIA AGRÍCOLA (CONBEA), XXII, Théus, 1993. Anais. Ilhéus: SBEA/CEPLAC. p.319-337. 
CLARK UNIVERSITY. Graduate School of Geography. IDRISI. version 2.0 for Windows. Worcester: Graduate School of Geography/Clark University, 1997.

CLARK UNIVERSITY. Graduate School of Geography. TOSCA. version 2.03. Worcester: Graduate School of Geography/Clark University, 1993.

FARRET, J.C. Aplicabilidade do georreferenciamento de aerofotos de pequeno formato na formação de bancos de dados espaciais - uma alternativa ao cadastro técnico rural municipal. Santa Maria, 1996. 111p. Dissertação (Mestrado) - Universidade Federal de Santa Maria .

FARRET, J.C; GIOTTO, E. Aplicabilidade do georreferenciamento de aerofotos de pequeno formato na formação de bancos de dados espaciais - uma alternativa para o cadastro técnico rural municipal. Ciência Rural, v.27, n.4, p.577-581, abr. 1997.

FIORIO, P. R. Avaliação cronológica do uso da terra e seu impacto no ambiente da microbacia hidrográfica do Córrego do Ceveiro da região de Piracicaba (SP). Piracicaba, 1998. 114p. Dissertação (Mestrado) - Escola Superior de Agricultura 'Luiz de Queiroz", Universidade Estadual Paulista.

FLORES, M.X. Uso agrícola do solo: principais tipos de solo, potencial de utilização e impactos ambientais. In: TAUK-TORNISIELO, S.M. et al. Análise ambiental: estratégias e ações. São Paulo: T.A. Queiroz/Fundação Salim Farah Maluf, 1995. cap.7, p.280-289.

JONES, J.R.; LANEY, R.; FULK, M.; AUBLE, J. TOSCA. Reference guide. version 2.0. Worcester: Graduate School of Geography/Clark University, 1993. 86p.

KOFFLER, N.F.; CAVALLI, A.C.; CHIARINI, J.V.; NOGUEIRA, F.P. Inventário canavieiro com auxílio de fotografias aéreas. Planalsucar, Piracicaba, 38p. 1979. 
KOFFLER, N.F.; MORETTI, E. Diagnóstico do uso agrícola das terras do Município de Rio Claro-SP. Geografia, v.16, n.2, p.1-76, out. 1991.

LANGRAN, G. Time in geographic information systems. London/Washington: Taylor and Francis, 1993. 189p.

LEPSCH, I.F.; BELLINAZI, R.R.; BERTOLINI, D.; ESPINDOLA, C.R. Manual para levantamento utilitário do meio físico e classificação de terras no sistema de capacidade de uso. Campinas: SBCS, 1983. 175p.

LO, C.P.; SHIPMAN, R. A GIS approach to land-use change dynamics detection. Photogrammetric Engineering and Remote Sensing, v.56, n.11, p.1483-91, nov. 1990.

MAFFINI, G.; ARNO. M.; BITTERLICH, W. Observations and comments on the generation and treatment of erros in digital GIS data. In: GOODCHILD, M.; GOPAL, S. Accuracy of spatial databases. London: Taylor \& Francis, 1994. cap.5, p.55-67.

MARCHETTI, D.A.B.; GARCIA, G.J. Princípios de fotogrametria e fotointerpretação. São Paulo: Nobel, 1978. 257p.

MEDEIROS, C.B.; BOTELHO, M.A. Tratamento do tempo em SIG. In: GIS BRASIL 96 / Congresso e Feira para Usuários de Geoprocessamento, Curitiba, 1996. Curitiba: Sagres, 1996.

MONTGOMERY, G.E \& SCHUCH, H.C. GIS data conversion handbook. Fort Collins: GIS world, 1993. 292p. 
MORAES, M.E.S.; ROCHA, H.O.; SCOPEL, I.; SÍRTOLI, A. Avaliação e comparaçào do uso da terra e classes de solos na microbacia do Rio Campo do Tenente (PR). In: CONGRESSO BRASILEIRO DE CIÊNCIA DO SOLO, XXIV, Goiânia, 1993. Cerrados: fronteira agrícola no século XXI. Goiânia: SBCS, 1993. p.379-380.

MURAMOTO, J.; SPAROVEK, G.; LEPSCH, I.F.; VIDAL TORRADO, P. Adequação do uso das terras de Piracicaba (SP). In: CONGRESSO BRASILEIRO DE CIÊNCIA DO SOLO, XXIV, Goiânia, 1993. Cerrados: fronteira agrícola no século XXI. Goiânia: SBCS, 1993. p.405-406.

OLIVEIRA, J.B.; PRADO, H.; BEJAR, O.I.G. \& LONGOBARDI, R.C. Carta pedológica semi-detalhada do Estado de São Paulo, Plano Cartográfico do Estado de São Paulo. São Paulo: Secretaria de Agricultura e Abastecimento, Coordenadoria de Pesquisa Agropecuária, Instituto Agronômico de Campinas e Secretaria de Economia e Planejamento, Coordenadoria de Ação Regional, Instituto Geográfico e Cartográfico, 1989. Folha de Piracicaba, Escala 1:100.000.

OLIVEIRA, M.T. de; PEREZ, L.O.; SAMPAIO, A.C.F. Ampliação e interpolação de curvas de nível: um estudo de caso. In: $17^{\circ}$ Congresso Brasileiro de Cartografia, Bahia, 1995. p.1139-46.

QUINTANILHA, J.A. Erros em bases digitais de dados espaciais para uso em sistemas de informação geográfica. São Paulo, 1996. 236p. Tese (Doutorado) - Escola Politécnica, Departamento de Engenharia de Transportes, Universidade de São Paulo.

RANIERI, S.B.L.; SPAROVEK, G. Evolução do uso das terras do Município de Piracicaba - S.P. (1962-1991). In: CONGRESSO BRASILEIRO DE CIÊNCIA DO SOLO, 24., Goiânia, 1993. Anais. Goiânia: Sociedade Brasileira de Ciência do Solo, 1993. p.387-388. 
SANTOS, A.P. dos; NIERO, M.; LOMBARDO, M.A. Interpretação de dados de sensoriamento remoto no uso da terra. In: Curso de Treinamento: Introdução às Técnicas de Sensoriamento Remoto e Aplicação. Manual. São José dos Campos: INPE, 1980. 318p.

SÃO PAUlO (Estado). Plano Cartográfico do Estado de São Paulo. São Paulo: Secretaria de Economia e Planejamento, Coordenadoria de Ação Regional, Divisão de Geografia, 1978. Folha 073/088 (Bairro Volta Grande), Escala 1:10.000.

SÃo PAULO (Estado). Plano Cartográfico do Estado de São Paulo. São Paulo: Secretaria de Economia e Planejamento, Coordenadoria de Ação Regional, Divisão de Geografia, 1979. Folhas 071/088 (Santa Terezinha do Piracicaba) e 072/088 (Bairro dos Marins), Escala 1:10.000.

SCHLAGEL, J.D.; NEWTON, C.M. A GIS-based statistical method to analyse spatial change. Photogrammetric Engineering and Remote Sensing, v.62, n.7, p.839-44, jul. 1996.

SILVA, J.R.C.; DEGLORIA, S.D.; PHILIPSON,W.R.; McNEIL, R.J. Estudo da mudança de uso da terra através de um sistema de análise georreferenciada. Revista Brasileira de Ciência do Solo, v.17, n.3, p.451-57, set/dez. 1993.

SIMPSON, S.R. Land law and registration. Cambridge: Cambridge University Press, 1976.

SPAROVEK, G.; LEPSCH, I.F. Diagnóstico de uso e aptidão das terras agrícolas de Piracicaba. Piracicaba: ESALQ, 1998.

SPAROVEK, G.; LEPSCH, I.F. Diagnóstico de uso e aptidão das terras agrícolas de Piracicaba. In: TAUK-TORNISIELO, S.M. et al. Análise ambiental : estratégias e 
ações. São Paulo: T.A. Queiroz/Fundação Salim Farah Maluf, 1995. cap.7, p.273279.

STAR, J. ESTES, J. Geographic information systems: an introduction. New Jersey: Prentice Hall Inc., 1990. 303p.

THAPA, K.; BOSSLER, J. Accuracy of spatial data used in geographic information systems. Photogrammetric Engineering and Remote Sensing, v.58, n.6, p.83541, jun. 1992.

VASCONCELOS, V.J.; CARDOSO, L.G.; BARROS, Z.X.; CAMPOS, S. Influência das mudanças na ocupação do solo sobre o processo evolutivo da erosão na bacia do Rio Araquazinho, São Manuel, SP. In: CONGRESSO BRASILEIRO DE ENGENHARIA AGRÍCOLA (CONBEA), XX, Londrina, 1991. Anais. Londrina: SBEA/IAPAR/Universidade Estadual de Londrina. p.32-53.

VETTORAZZI, C.A. Sensoriamento remoto orbital. Piracicaba: ESALQDepartamento de Engenharia Rural, 1992. 134p. (Série Didática, 2).

WALSH, S.J.; LIGHTFOOT, D.R.; BUTLER, D.R. Recognition and assessment of error in Geographic Information Systems. Photogrammetric Engineering and Remote Sensing, v.53, n.10, p.1423-1430, oct. 1987.

WARNER, W.S.; GRAHAM, R.W.; READ, R.E. Small format aerial photography. Latheronwheel: Whittles Publishing, 1996. 292p.

WOLF, P.R. Elements of photogrammetry. New York: McGraw-Hill Book Company, 1983. 628p. 